DEPARTMENT' OF THE INTERIOR

UNITED STATES GEOLOGICAL SURVEY

CHARLES D. WALCOTT, DIRECTOR

TH E

\title{
FAIRHAVEN GOLD PLACERS, SEWARD PENINSULA, ALASKA
}

$\mathrm{BY}$

FRED H. MOFEIT

WASHINGTON

GOVERNMENT PRINTINA OFFICE

1905 

DEPARTMENT OF THE' INTERIOR

UNITED S'TATES GEOLOGICAL SURVEY

CHARLES 1). WALCOTT, DIRECTOK

T H E:

\section{FAIRHAVEN GOLI) PLACERS, SEWARI) PENINSULA, ALASKA}

BY

FREI II. MUFFIT

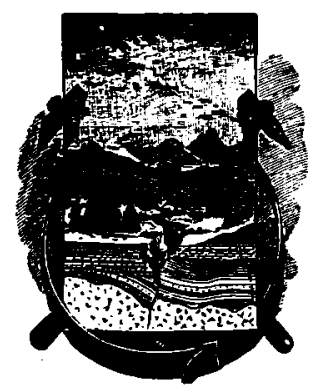

W ASHINGTON

GOVERNMENT PRINTING OFFICE

1905 



\section{CONTENTS.}

Page.

Letter of transmittal__. 7

Introduction - -

Geography -

Shore line

Drainage -...-

Relief - ......

General geology

Introduction -

Metamorphic series _._-_._.

General statement _...

Schistose rocks _.

Limestones -

Structure -

Aye _.......... 23

Unwetamorphosed sediments_........

Age -

Igneous rocks

General statement

Granites and associated granular rocks _-

Age -

Andesites . .

Basalts _._. 31

Age -

Dynawic history

Surficial deposits

General statement _._. 37

Stream and beach gravels

Marine and rivel terraces _._._. 39

Glacial deposits_-_-_._- 40

Residual soil _..._._. 40

Ground ice ....-_- 40

Mammalian remains .

Development of topography

Introduction -

Kugruk Platean

Terraces -

Lowlands -

Later geologic history $y_{-}$

Economic geology _...

Location of gold field._... 47

Geography -......... 47 
Economic geology-Continued. Page.

History _. 49

Description of the creeks . .

Inmak buk batsin _......... 52

Hannum Creek ......... 52

Cunningham Creek

Collins Creek-_- 54

Old Glory Creek .

Nelson Gulch

American Creek_._.

Pinnell River....... 57

Perry Creek _...

Intuachuk River -

Kiwalik basin

Candle Creek _....... 60

Buckland River basin _._. 63

Bear Creek._..... (i3

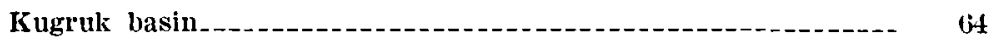

Dixie Creek _.... 64

Alder Beach..................

Source of the gold

Summary -

Coal _..._-

General conditions...

Trails - - - 68

Mail service -- 70

Economic conditions.

Climate - 71

Natives

Fish and game

Timber and vegetation. 78

Index - 


\section{ILLUSTRATIONS.}

Plate I. Outline map of Alaska, showing areas covered by larger scale maps, Pls. II and III

II. 'Topographic reconnaissance map of northeastern portion of Seward Peninsula

Page.

III. Geologic reconnaissance map of northeastern portion of Seward Peninsula

IV. A, "Schist Monuments," 10 miles north of Kiwalik Mountain. due to weathering; $B$, Erosion features in granite near Asses Ears

$V . A$, West cone of Asses Ears, taken from a point on east cone in feet from the top; $B$, Asses Ears, looking southeast, distance 1 mile

VI. A, Lava flow on cottonwood creek; $B$, Roly surfice of recent lava flow between the forks of Kuzitrin River.

VII. A, Fissure in recent lavas between the forks of Kuzitrin River, caused by the sinking of the hardened surface after the molten lava below had flowed out from either side; $B$, Recent lava flow hetween the forks of the Kuzitrin

VIII. A, Lava rin on the lower Inmachuk: $B$, Terraced granites east of Kiwalik River.

IX. $A$, Sluicing on Hannum Creek ; $B$, "Hot Springs" on upper Inmachuk River.

$\mathrm{X} . A$, Nelson Gulch; $B$, Automobile boiler used for thawing frozen gravels on Inmachuk River

XI. A, Dam on the lower Inmachuk for diverting the streain from its bed; 1s. I'ump on lower Inmachuk

XII. A, Sluicing on Inmachuk River; 1 , Candle, on Kiwalik River at mouth of candle creek

XIII. A, China pump on candle ('reek; $B$, Bench claim on Candle Creek, showing 12 feet of ice above the gravel

XIV. A, Boiler for thawing frozen gravels on Candle Creek; $B$, Winter cabins on Immachuk River

2. Diagrammatic sketch showing the oreurrence of liva flows in some of the valleys south of Kotzebue sound 



\title{
LETTER OF TRANSMITTAL.
}

\author{
Dfpartment of the Interior, \\ United States Geological Survey, \\ Washington, D. C., May $2,1904$.
}

SIR: I have the honor to submit herewith the manuscript and illustrations of a report entitled "The Fairhaven Gold Placers, Seward Peninsula, Alaska," by Mr. Fred H. Moffit, assistant geologist, and to recommend its publication as a bulletin.

This manuscript is based on a geologic and topographic reconnaissance survey, made during the summer of 1903 , of an important placer-gold district in the northeastern part of Seward Peninsula. The report is accompanied by a reconnaissance map by Mr. D. C. Witherspoon, topographer, under whose directions the field operations were carried out.

Surveys were begun in Seward Peninsula in 1899, soon after the discovery of the rich placers of Nome, and, in view of the great economic importance of the field, have been extended as rapidly as the appropriations permitted. It was early recognized that here, as elsewhere in Alaska, it would be better to obtain general topographice and geologic results, to be immerliately available to the mining public, than to attempt exhaustive surveys and studies of small areas. This has been the guiding policy in formulating and executing the plans. As a resilt, there have been issued a number of publications (including reconnaissance maps) which, though only of a preliminary character, have been, because of their timeliness, of much value to the mining public.

With the appearance of the following report this first epoch in the surveys will have closed, for there will be available complete reconnaissance reports and maps of the entire Seward Peninsula. These general reports and maps should be followed by more detailed surveys; these have been begun, and it is purposed to carry them forward as rapidly as circumstances will permit. In taking up areas for detailed investigations the attempt will be made to study first those of greatest economic interest.

Very respectfully,

Alfred H. Brooks,

Geologist in Charge of Division Alaskan Mineral Resources.

Hon. Charles D. Walcott,

Director United Staies Geological Survey. 



\title{
THE FAIRHAVEN GOLD PLACERS, SEWARD PENINSULA, ALASKA.
}

\author{
By Fred H. Moffit.
}

\section{INTRODUCTION.}

The presence of extensive gold deposits in the gravels of Seward Peninsula was first definitely determined in 1898 . In the five years that have passed since the beginning of active mining on $A$ invil Creek and the discovery of gold in the sands of the Nome beach the value of the production of Seward Peninsula has amounted to more than three times the original purchase price of the Territory of Mlaska, and the number of its white inhabitants has increased from less than a score to between three and four thousand during the winter, and several times that number during the summer.

The investigations of the United States Geological Survey on Seward Peninsula were begun in 1899 by Mr. Nlfred II. Brooks and Mr. Frank C.S Schrader, who had spent the summer in independent reconnaissance work in widely separated regions of the Alaskan interior and had met at St. Michael after descending the Yukon on their way ont from the field of work. They were attracted by the reports of wonderful discoveries marle by prospectors at Nome and determined to spend the last few days of the season in the new eamp, the hills of which were already partly covered by the early winter snows. Their report, together with a topographic map by Mr. D. C. Witherspoon, covering a small area of about 200 square miles, was made ready and published as quickly as possible, in order that it might be of assistance to prospectors at the opening of the following season. ${ }^{a}$

The importance of the gold deposits led to more extended investigation during the next summer, three parties being organized for the purpose. Mr. Brooks was placed in charge of the geologic work and Mr. E. C. Barnard in charge of the topographic work in the

a Schrader, Frank C.., and Brooks, Alfred H., Preliminary Report on the Cape Nome Gold Region, Alaskil, T. S. Geol. Survey, 1900. 
Nome region, Mr. Brooks being assisted by Mr. Arthur J. Collier and Mr. George B. Richardson. In the Norton Bay region the study of the geology was made by Mr. Walter C. Mendenhall, who was assigned to the party in charge of Mr. W. J. Peters, topographer. The report ${ }^{a}$ on the season's work includes a description of the placergold deposits and main features of the geology, a discussion of the development of the physiographic character, and a topographic map of most of the southern part of Seward Peninsula.

In extension of this work dluring the next summer, 1901, a geologic reconnaissance of the northwestern part of the peninsula " wats completed by Mr. Collier, and the area was mapped by Mr. T. G. Gerdine, topographer in charge of the party. In the latter part of the same summer Mr. Mendenhall made a brief investigation of the more prominent geologic features in the vicinity of Point Blossom and Spafarief Bay, in the southeastern part of Kotzebue Sound. The labors of this season completed the topographic mapping of approximateTy three-fourths of the peninsula. No work in the area was indertaken by the Survey in 1902, but the increasing importance of the gold production of the Nome region and the possible value of the little-known tin deposits of the York region, as well as the development of a valuable gold field south of Kotzebue Sound, led to the continuance of geologic and topographic work in 1903 . It was desired to secure more detailed information concerning the occurrence. of the valuable metals, to establish more definitely the relations of the geologic formations, and especially to complete the topographic mapping of the peninsula. With these objects in view two parties were sent into the field; one, in charge of Mr. Collier, with $\mathrm{Mr}$. Frank L. Hess as assistant, continned the investigation of the western and northern areas; the other, in charge of Mr. D. C. Witherspoon, topographer, undertook the work of extending the mapping in the northeastern part of the peninsula, including most of the Fairhaven mining precinct and also portions of the Goodhope, Kugruk, and Koyuk precincts. (See map of mining precincts, fig. 1.)

To the last-mentioned party the writer was assigned, with instructions to make a geologic reconnaissance of the area mapped and to visit the creeks and study the gravel deposits where gold was being mined. The party included, in addition to those mentioned, C. E. Hill, field assistant; S. W. Johnson, packer; B. W. Witherspoon, assistant packer; John Aldridge, A. G. Hill, I. D. Stuver, and S. D. Mathews, camp hands.

a Brooks, Alfred H. ; Richardson, George B.; Coller, Arthur I., and Mendenhall, Walter C., Reconnaissances in the Cape Nome and Norton Bay regions, Alaska, in 1900, U. S. Geol. Survey, 1901.

- Collier, Arthur J., Reconnaissance of the not thwestern portion of Seward PenInsula, Alaska : Prof. Paper U. S. Geol. Survey No. 2, 1902. 
The two immediate objects which it was expected to accomplish were the completion of the topographic map of the peninsula and the procuring of information concerning the placer-gold deposits discovered in 1901 on Candle Creek and the tributaries of Inmachuk and Buckland rivers; and, in addition, the hope was entertained that data which would throw light on the origin and source of the gold and on the structural relations of the gold-bearing rocks would be obtained.

The necessary equipment of 13 pack horses and provisions for three months were secured in Seattle and shipped, part to Nome, the remainder to Teller. Both parties assembled in Seattle and sailed on the steamship Centennial June 3, reaching Nome on June 16.

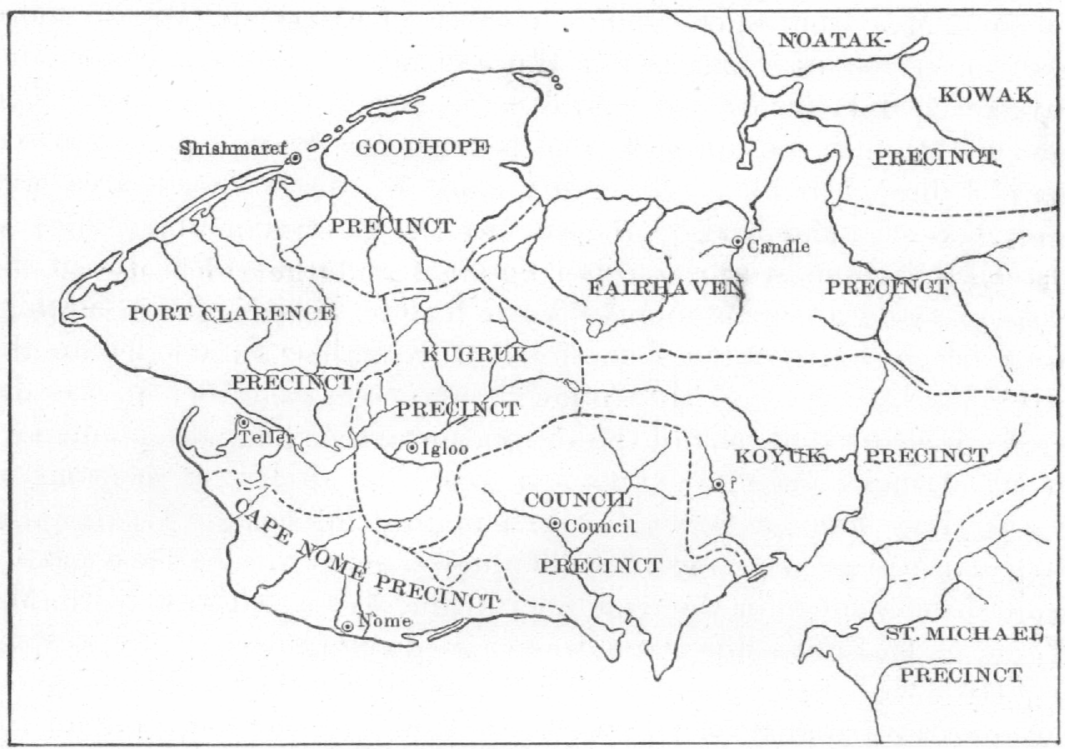

Frg. 1.-Precinct map of Seward Peninsula, showing the recording offices.

Some time was consumed in resacking the provisions and breaking in the horses to the work of carrying them. In order to save the animals and to prevent double trips, reshipments were made at Nome and provisions sent to Teller, on Port Clarence, and to Deering and Kiwalik, on Kotzebue Sound, where they could be reached later in the season. The previous winter had been a long one; deep snows were not yet melted on the north side of the hills, and a further delay in beginning the overland journey was caused by tardiness of the spring season and consequent scarcity of good grass for the horses.

On June 21 the pack train was sent north with hay and oats, in care of five men, who made a cache near the head of Dorothy Creek, in Nome River Valley, and returned to camp three days later. On June 27 the Nome camp was abandoned and all, with the exception 
of Mr. Witherspoon, moved out on the trail which led north along Nome River and Salmon Lake to Kuzitrin River. The 65-mile march from Nome to Lanes Landing was not completed till July 8, for the horses were not yet accustomed to the work and it was necessary during that part of the journey to make double trips with provisions for the men and feed for the horses. At Kuzitrin River high water and quicksand made crossing somewhat difficult, and when a fording place conld not be foind the packs were boated over to the north shore and the horses made to swim the stream.

At Lanes Landing the party was divided, Mr. C. E. Hill and the writer, with two men, pushing east, to tie up with triangulation points established by the topographers in 1900 and to begin the work of mapping, and the other's going down the Kuzitrin to Marys Igloo with eight horses to meet $\mathrm{Mr}$. Witherspoon, who was expected to have reached Teller by boat and to have come up the river with that part of the outfit sent around from Nome. Mr. Witherspoon did not reach Teller until July 12. being unable to enter Port Clarence till after the ice melted, since the surface of that inland basin is not disturbed by the storms on Bering Sea, and the thick ice is not broken up and given an opportunity to float away, as is the case along Nome beach. Mr. Witherspoon joined the smaller party at Eldorarlo Creek on July 20, and the following day sent back one man with horses to secure that part of the supplies which he had been obliged to leave at Lanes Landing.

Two days later, at Berry Creek, a plan of operations for the first part of the season having been definitely decided on, the party was again divided, and for the remainder of the season, with the exception of one or two days, the work was carried on from separate camps. Mr. Ifill, with two men and four horses, advanced the topographic work northward along the divide between Shishmaref Inlet and (roodhope Bay, thence eastward through the district adjacent to Kotzebue Sound as far as Kiwalik. The main party carried the topographic and geologic mapping eastward, across the upper Cottonwoorl and north of the Asses Ears, to Pinnell River, making detours to north or south as the conditions of the work required. At Cottonwool Creek, however, the writer spent a few days in examining the placer deposits of the upper Inmachuk, Hannum Creek, and Nelson Gulch, joining Mr. Witherspoon again on August 1 at the mouth of Old Glory Creek. Since the interests of the different branches of work now lay in separate regions, Mr. Witherspoon proceeded south and east to the upper drainage basin of Kugruk River, while the writer remained a week longer to examine the gold gravels on Old Glory, P'innell River, and Inmachuk River, then moved east to the Kugruk, where the coal mine on Chicago Creek was visited, and finally started south to join the main party. This was not found till 
August 13, near the mouth of Independence Creek; the work of the topographers had been interfered with by smoke from burning tundra, and they had not been able to move northward as rapidly as had been expected. From the Kugruk the party went east again across the head of Candle Creek, then sonthward to Kiwalik Mountain. A little snow fell on Alugust 26 , and cold nights with thin ice gave further warning of the approach of winter. Much work still remained to be done. Traveling almost directly east, the party crossed Kilwalik River and then turned toward Candle, where it expected to renew the rapidly failing provisions from the supply shipped to Kiwalik and to meet the Hill party, which was coming castward along the sound. Candle was reached September 2, and Hill arrived three days later. Four days were spent at Candle in visiting the creek claims, rearranging the packs, and laying out the work for the remaining few weeks of the season. On September 7 all hands moved east and remained together till September 9, when the parties separated for the last time, Hill going directly east toward Buckland River, the rest traveling southeast toward Bear Creek, a tributary of the Buckland, on which some gold was being mined. It was hoped that Hill's party, after spending a few days on the north end of the Kiwalik-Buckland divide, could move quickly to the upper part of the Koyuk Valley, map the area between Koyuk and Kuzitrin rivers, and then return to Nome by way of the Salmon Lake and Nome River trail before the winter weather began. Mr. Witherspoon wished to complete the topography of the same divide as far south as Koyuk River, then cross the Darby Mountains to the valley of Fish River, and reach Nome by way of Council.

By September 13, when Eagle Creek was reached, bad weather was becoming prevalent; the cold nights were rapidly killing the grass on which our horses were entirely dependent for feed, and a fall of several inches of snow on September 18 warned the party that work must soon be given up entirely. The Koyuk Valley was crossed with difficulty, for the flat, wet lands of the bottom were intersected by olıl. abandoned stream channels and deeply incised by existing watercourses; one horse was killed on the way and the others were in such a weakened condition from lack of food that it was not found possible to move more than 5 or 6 miles a day, and on September 21 it was reluctantly decided to give up the trip across the mountains, to lighten the packs of everything that could be spared, and to return to Kiwalik through a familiar country rather than to attempt an untraveled trail known to be difficult except in winter. The 50 miles to Candle was covered in five days, and after disposing of the horses and camp furniture at public auction the party proceeded down the river by boat to Kiwalik, to await the arrival of a steamer already overdue. Kiwalik was reached on the evening of September 
26, and four days later transportation to Nome was secured on the steamship Saidie. The trip around the coast, through Bering Strait, was accomplished in three days, a short stop being made at Teller, and Nome was reached on October 3 , where the Hill party had arrived the day previous. At Nome the remaining horses were sold, and after a rough ten-day voyage on the steamship Valencia the party reached Seattle on October 16, having accomplished the principal objects for which it was sent.

An area of 6,400 square miles was mapped on a scale of $1: 180,000$ and the topography sketched with a contour interval of 200 feet. This map, here published on a scale of $1: 250,000$, includes all the drainage of Goodhope, Inmachuk, Kugruk, and Kiwalik rivers as well as the leadwaters of Koyuk and Kuzitrin rivers, the western tributuries of Buckland River, and the drainage into the western side of Kotzebue Sound. This work was based on points established by topographers of the United States Geological Survey in 1900, and the horizontal and rertical control was cxtended from these points into the field of work by triangulation and vertical angles, supplemented by the barometer.

The geologist visited all the gold-producing creeks of the region, except Bear Creek, and made a geologic recomnaissance of the area traversed. A continuous traverse was kept by pacing and compass bearings, and the topography along the route was sketched in with the aid of the barometer. The geologic data collected during this traverse have been transferred to the topographer's map and are given in this report.

\section{GEOGRAPHY.}

The region which forms the subject of this paper occupies the northeastern portion of Seward Peninsula (Pls. I, II, and III) and comprises a little more than one-quarter of its total area, or about 7,500 square miles. It includes the whole of the Fairhaven mining precinct except that portion lying to the east of Buckland River, the eastern portions of the Goodhope and Kugruk precincts, and the northern portion of the Koyuk precinct (see precinct map, fig. 1, p. 11). It is limited on the west by the north-south ridge extending from Baldy Mountain to Devil Mountain, and on the east by Buckland River. Its northern boundary is formed by the Arctic Ocean and Kotzebue Sound, and it extends southward to the Bendeleben Mountains and lower Koyuk River. Expressed in another way, it may be said that nearly all the district is included, in an east-west direction, between meridians $161^{\circ}$ and $164^{\circ} 30^{\prime}$, and in a north-south direction, between parallels $65^{\circ} 15^{\prime}$ and the Arctic Circle, which crosses the northward projection of the peninsula just south of Cape Espenberg. If the northerly lowlands west of 
极 
振 
Goodhope Bay be neglected, the area is roughly a rectangle with its long dimension extending from east to west.

Shore line.-The shore line from Cape Espenberg to Elephant Point has a length of slightly over 100 miles, broken at several places, notably at the mouths of Kugruk and Kiwalik rivers, by shallow bays or lagoons nearly cut off from the sound by low sand spits. Along the west side of Goodhope Bay the bordering lands for many miles inland are flat and low, but the southern shore is a succession of low headlands and plains, which mark the extension of the north-south ridges and intervening valleys of the-interior.

The barrier beaches and inclosed lagoons, which form so noticeable a feature of the Arctic shore line, are not present on the Kotzebue coast.

Kotzebue Sound was discovered by Otto von Kotzebue in 1816, and since that time has been frequently visited by vessels sailing the Arctic Ocean, since it affords protection against all storms, excepting those from the northwest. The sound has an average depth of about 5 fathoms, the shallowest waters being found along the east and west shores. At present the two small steamers which make regular trips with mail and freight touch at Deering, at the mouth of Inmachuk River, at Kiwalik, on Spafarief Bay, and at Point Blossom, on the east side of the sound; cargo is occasionally landed at other points along the beach. At high tide small vessels may enter behind the sand spit on which Kiwalik is built, but must do so with care, for at low water even light dories may be caught on the mud banks of the lagoon.

Drainage.-The drainage of the region, as will be seen from the map, is not simple, part of it reaching Bering Sea by various ways and part the Arctic Ocean. The waters flow northward into Kotzebue Sound from considerably more than half the mapped area. The southern part is drained by the two largest rivers of Seward Peninsula: the Kuzitrin, with its large northern branch, the Noxapaga, flows westward to Imuruk basin, and thus to the sea; heading against the Kuzitrin on the east is the Koyuk, which flows to the southeast and reaches Norton Bay at the extreme eastern limit of the peninsula. In a general way the streams making up the Arctic drainage have north-south direction, the smaller ones, especially, showing a parallelism which is quite noticeable. The most important of these streams, named from west to east, are Goodhope, Inmachuk, Kugruk, Kiwalik, and Buckland rivers.

The largest of these is the Buckland, the longest branch of which, however, does not lie in the peninsula. Kugruk River has a length of almost 60 miles, Goodhope and Kiwalik rivers about 50 miles, and the Inmachuk nearly 30 miles. The present streams occupy shallow valleys which lie but a few hundred feet below the general level of 
an old dissected plain. The upper valleys are steep and narrow, but broaden and are covered with extensive gravel flats as they approach the sea. Kugruk River, throughout a considerable portion of its lower course, occupies a level valley, frequently as much as a mile or two in width, traversed by channels through which the river once ran. In places these old channels are nearly the whole width of the valley from the present course. An interesting fact brought out by the topographic map is that the ridge from Midnight Mountain to Devil Mountain is broken through by Nugnugaluktuk River, which has its source on the west and flows eastward to Goodhope Bay. A similar case is seen east of Candle, where the unnamed creek draining the west side of the ridge between Kiwalik and Buckland rivers follows northward along the lower slopes and then turns east to the Buckland.

One or two small lakes are located in the level region forming the watershed against which the Arctic and Bering sea drainage heads. Lake Imuruk is the largest of these, and covers an area of about 25 square miles. As will be shown later, these lakes are due to the damming of streams by lava flows. So nearly level is the lava-covered plain on which the lakes lie that the prospectors, who rarely cross the region excepting in winter, were generally unable to tell into which of several streams the waters of Lake Imuruk are emptied.

Relief.-As has been stated, the district is inclosed on three sides by more or less continuous ridges. On the south are the Bendeleben Mountains, which take their name from Mount Bendeleben $(3,700$ feet), the highest point on the peninsula east of the Kigluaik or Sawtooth Mountains. On the west is the Midnight Mountain ridge, reaching an elevation of 2,600 feet in Midnight Mountain itself. On the east is the high divide between the Kiwalik and Buckland, which extends from Koyuk River to Eschscholtz Bay. The smooth, rounded contours of the limestone and schist hills of the western ridge are in strong contrast with the deeply trenched valleys and sharp ridges of the eruptive mass on the east. The highest elevation of this watershed is about 2,600 feet, but the abrupt rise from the lowlands of the river's gives an appearance of greater height. The southwest and southeast angles of the rectangle formed by these three ridges are occupied by the valleys of Kuzitrin and Koyul rivers.

Both of these rivers are exceedingly crooked and are many times longer than the actual distance from source to mouth. The floors of the two valleys are but slightly above sea level and are made up of extensive gravel deposits, over which are scattered scores of small lakes and ponds. This flat land is well-nigh impassable in the summer months, but affords good traveling when frozen.

Within the boundaries of the rectangle described, the region of greatest relief appears on the west of Kiwalik River and finds its highest elevation in Kiwalik Mountain (2,400 feet), from which point 
northward the ridges gradually become lower as the rounded hills bordering the sound are neared. The Asses Ears have an elevation of almost 2,000 feet, although the twin cones themselves are only 200 feet higher than the plain above which they rise.

The northward projection of the peninsula is a country of very low relief, and the coastal plains bordering the Arctic Ocean and Goodhope Bay are broken only by mounds of gravel or by lava masses like that of which Devil Mountain is composed. A depression of 200 feet would put much the greater part of the area below the sea, making an island of the mountain, as it probably was at no very distant time.

Viewed as a whole, the northern part of Seward Peninsula is characterized by general low relief and monotonous appearance.

\section{GENERAL GEOLOGY.}

\section{INTRODUCTION.}

After a hasty reconnaissance through a little-known or entirely new region, such as is the greater part of the district of Alaska, the geologist feels, on his return from the field, that his notes are characterized chiefly by the large number of puzzling questions which are suggested, rather than by the definite establishment of facts and their relationships. It follows that the results are incomplete and unsatisfactory, that many things are assumed without definite proof, and that more detailed examination in the future will probably modify or even change entirely some of the conclusions reached. This must necessarily be so from the character of the country, the short season, and the varied conditions under which the work is carried on. Much of the geologist's time and strength are taken by duties entirely aside from the observation of geologic phenomena, and, in any case, he learns; only such facts as may chance to appear near his route of travel, thus missing oftentimes the important key localities of a region. Nevertheless, in spite of all these difficulties, he should be able, at the end of his field work, to establish some general conclusions and provide a basis for future work which will be of real value.

The rocks of the region adjacent to Kotzebue Sound on the west and south are made up in great part of micaceous, chloritic, and graphitic schists, derived from sediments. Interstratified with the schists are beds of limestone of no great thickness, often containing argillaceous matter and less frequently a large proportion of graphitic material. The limestones are very subordinate in amount to the schists in which they occur, and in many cases possess a schistose structure or a poorly developed cleavage.

The schists and thin limestones are underlain, at least in the western

Bull. $247-05 \mathrm{M}-2$ 
portion of the region, by massive crystalline limestones, or by marbles which by a decrease in lime and increase of argillaceous matter grade vertically into them. The marbles are white or bluish white in color and, like the thin-bedded limestones, frequently show a platy or schistose structure. Erosion of the overlying sediments has brought the massive limestones to the surface in places, where they appear as rounded hills in small isolated areas surrounded by schists.

The sedimentary deposits are intruded in a number of localities by stocks of granite and quartz-diorite, with other related eruptives, and are almost entirely cut off along the eastern border of the region by a great igneous mass composed chiefly of extrusive material, mostly andesite, with a central core of granite.

Long after the deposition of these older sediments there was laid down upon them a series of coal-bearing beds, which are folded but not altered as are the rocks on which they lie. They are found in the valleys of Kiwalik and Koyuk rivers, and are so limited in distribution that they might easily escape notice.

The sedimentary and igneous rocks were subjected to various movements, both vertical and horizontal, and were exposed to erosive agencies during a very long period, which was interrupted by a series of recent lava flows affecting nearly the entire region, but more widely developed in the southern and central portion. These lavas are basaltic in character and cover many square miles in the region of the upper Kuzitrin and Koyuk rivers. To the northward they are chiefly observed along the sides of the valleys, where they have been cut through by streams and appear as walls or rims of loose blocks. They also occur as residual buttes in several localities, and are closely associated with the andesites of the eastern part of the region.

The most widely extended of the geologic formations are gravels, which cover the valleys of all the streams and form extensive lowlands bordering the coast and the inland basins. They are of local origin and contain waterworn material derived from the rocks which they cover and also from the lavas whose later flows sometimes overlie them.

The accompanying geologic map (Pl. III) represents an area of about 7,500 square miles; nearly 6,500 square miles of this was investigated during the season of 1903 , and the remainder is based on the previous work of Mendenhall and Collier. It is intended to show the areal distribution and structural relations of the different formations as accurately as it was possible to establish them during the short season of work, but it should be borne in mind that in many points the boundaries are only approximate, since the scarcity of outcrops, resulting from the moss-covered condition of much the larger part of the region, made it quite out of the question to trace them carefully even if time had permitted. 
In the following pages it is proposed, first, to describe the metamorphic complex which comprises the oldest rocks of the region and, in connection with this, the younger overlying coal-bearing beds; second, to describe the igneous rocks which in some places were injected into and in others poured out over the sedimentaries; and third, to give some account of the surficial deposits, especially the gold-bearing gravels, resulting from the action of water and the decay of the bed rock.

The writer wishes to express his indebtedness to Mr. Witherspoon for specimens collected near the head of Kugruk River, and to $\mathrm{Mr}$. Hill for geologic material from the Devil Mountain and Goodhope Bay regions, tasks which they kindly consented to undertake in addition to their regular topographic work

\section{METAMORPHIC SERIES.}

GENERAL S'TA'I'EMEN'T.

Under the head of "Metamorphic series" are grouped together a number of rock types of widely different character, the relationships of which are difficult to establish clearly, and the ages of which are in doubt. They possess the common characteristics of having been in all cases greatly altered from their original condition at the time of consolidation. The changes include the folding of the beds and the production of secondary structures, such as schistosity, cleavage, jointing, or faulting, resulting from pressure and the varions movements of the rock mass; the recrystallization of the mineral constituents and the development of new minerals; the infiltration of quartz, giving the numerous veins, stringers, and lenses of that mineral which are so frequent in the outcrops and are so important in some places because of their gold content; the peculiarities of structure due to the intrusion of large masses of igneous rock, and other less noticeable features. The series includes massive and thin-bedded crystalline limestones and marbles, banded black and gray slates, and a variety of schistose rocks, both sedimentary and igneons, among which are micaceous. graphitic, quartzose, chloritic, feldspathic, and amphibolitic phases. 'The failure to secure fossil remains from the much-altered sediments and the presence of an extensive lava sheet over almost the entire central area make the subdivision of the schists a difficult task that can be accomplished successfully only after a more detailed study of the region. The occurrence of the metamorphic series in the Norton Bay region on the south side of the peninsula was described by Mendenhall in $1900, "$ who also gives some account of the series as it appears

a Mendenhall, Walter C., A Reconnaissance of the Cape Nome and Norton Bay Regions, Alaska, in 1900, U. S. Geol, Survey, 1901, pp. 199-204. 
on the north side of the peninsula, in the neighborhood of Deering, Kiwalik, and Point Blossom. ${ }^{a}$

The metamorphic complex here described occupies practically the entire mapped area west of the Kiwalik, except where it is intruded by granular igneous rocks, which for the most part are unaltered, or is covered by lava flows. For convenience in description the metamorphic rocks are separated into two divisions, the first treating of the schistose varieties, the second of those which in the main are massive, yet do at times possess the schistose structure in a less degree.

SCHISTOSE: ROCKS.

The schistose rocks are distributed over a much greater area than are the other members of the metamorphic series. The outcrops are most often found in valleys, where the streans have cut through the lava sheet and exposed the older rocks beneath, but at times they appear above the general level of the lava flow, on the higher parts of the low dome-like hills which characterize the topography, in some places making known their presence in the higher elevations by the striking monument-like forms which they assume on weathering (I'l. IV, A). Monument Mountain, west of Glacier Creek, affords one of the best examples of this peculiarity. Viewed from a distance, the broken contour of the ridge is strongly contrasted with the more even and regular lines of the hills to the west and north, where for some reason these irregular forms are not developed. They are most probably due to the presence of two systems of vertical joint planes, which permitted the weathering agencies to attack the rocks more quickly along such places of weakness and to penetrate more deeply than might otherwise have been possible.

The schistose rocks comprise a variety of types of different appearance and different mineral composition, but for the most part they are undoubtedly of sedimentary origin, this being shown by the presence of frequent thin-bedded limestones and graphitic phases and by occasional quartzites. Micaceous schists are the prevailing ones, but with them appear siliceous and graphitic variations, more rarely feldspathic, amphibolitic, and granetiferous types. The presence of intruded greenstone is very much less common than is the case in the western portion of the peninsula, where the structural relations are easily recognized and the metamorphism has not, in the majority of cases, been so great as to destroy the original features of the rocks.

In passing eastward from the Kugruk River region, one notes a transition from the massive limestones forming the north-south ridge in which Harris Dome stands, through limestones of a schistose character and calcareous schists, to the mica-schists in the neighborhood

a Mendenhall, Walter C., Reconnaissance from Fort Hamlin to Kotzebue Sound, Alaska ; Prof. Paper U. S. Geol. Survey No. 10, 1902, pp. 35-36. 


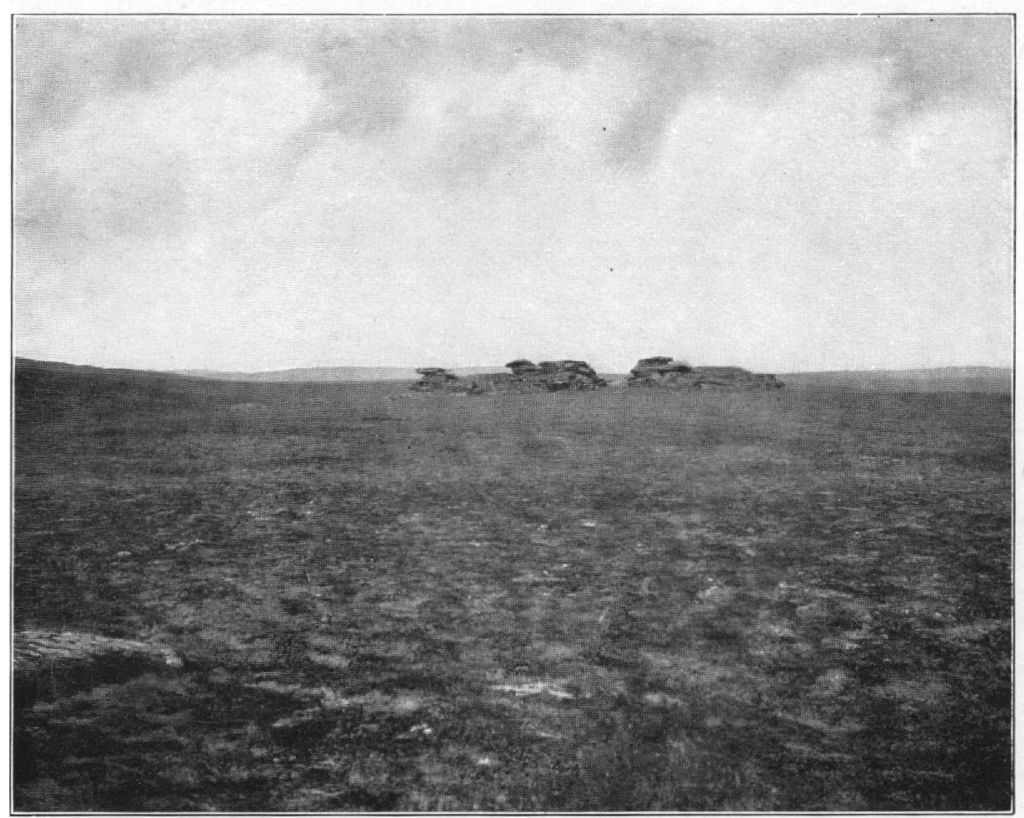

A. "SCHIST MONUMENTS," 10 MILES NORTH OF KIWALIK MOUNTAIN, DUE TO WEATHERING.

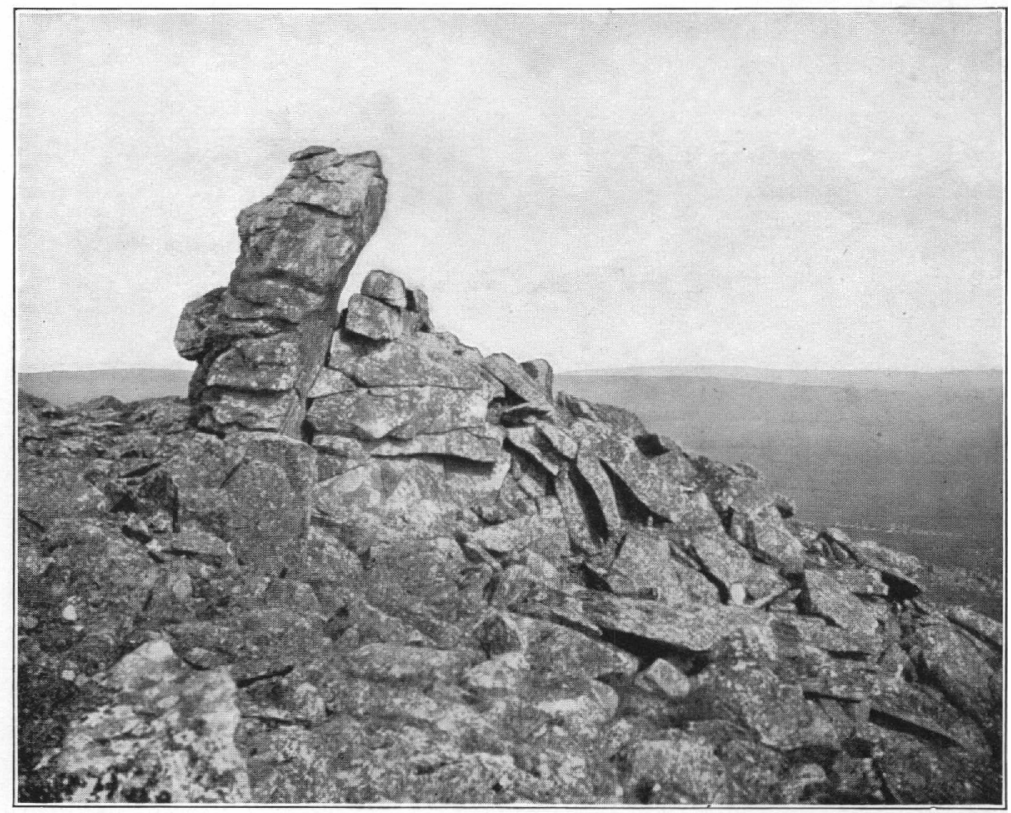

b. EROSION FEATURES IN GRANITE NEAR ASSES EARS. 

of Eldorado Creek. These schists are frequently graphitic and often calcareous. In the vicinity of Hammum Creek banded slates are seen, and on Pinnell River many quartzose beds occur, with an occasional heavy bed of quartzite. Schists with a silvery luster and satin-like feel are common in the vicinity of Candle Creek. Garnetiferous varieties are less common in the western and central part of the district than in the northern. Highly siliceous or quartzose schists cover a considerable area between Midnight Mountain and Devil Mountain and south of Goodhope Bay, as well as to the north and east of Spafarief Bay. These schists are at times graphitic.

An unusual phase of the metamorphic rocks appears in Kiwalik Mountain and in the adjacent hills, which are made up of a schistose granite or gneiss with occasional dark biotitic variations. These gneisses, which cover an area of about 15 or 20 square miles and include the highest elevations in the central part of the region represented by the map, form a striking feature of the landscape because of a black lichen everywhere present on them, which contrasts strongly with the white outcrops of the limestone, often enabling them to be distinguished at a distance from the neighboring sedimentary schists. The original granite from which the gneisses are derived has been so altered by the movements that took place in it that its true character was at first somewhat in doubt, but was brought ont more clearly by the microscope.

The gneisses are followed on the north by mica-schists interstratified with occasional beds of white marble, which contain needles of beautiful green tremolite. Schists and limestones appear in the valleys both to the east and to the sonth, but no contacts were seen, and their exact relations to the granite could not be definitely shown. The latter probably belongs to a series of intrusions that were widespread in the peninsula and have greatly altered many of the older: formations.

Similar gneisses are widely developed south of the upper part of the Koyuk, and from the degree of alteration it seems probable that they and the Kiwalik Mountain area may be of similar age, and that both are older than the Kiwalik-Buckland granites, as will be shown later. In weathering, the gneisses break into large angular blocks, covering the tops and sides of the hills with a great mass of débris difficult to traverse on foot and totally impassable with horses.

\section{IIM ESTONES.}

Limestones are of much more limited distribution in the eastern part of Seward Peninsula than is the case in the western portion, where they are widely developed and cover many square miles of country. They appear as great masses of white crystalline limestone or marble, often with a platy structure, and as black, gray, bluish- 
gray, and sometimes white crystalline beds in the schists. When impure they may grade into calcareous or graphitic schists or siliceous limestones. Thin-bedded limestones are interstratified with the schists, but present no features of special interest, and their occurrence in the placer districts will be referred to later.

As has been stated previously, the massive limestones of the Harris Dome region pass by a gradual transition into micaceous schists east of Eldorado Creek. The change is not entirely a uniform one, since limestone beds and schists frequently alternate, but the decrease of the lime from the west toward the east is noticeable and gives evidence of changing conditions of sedimentation at the time these rocks were being deposited.

Northeast of the Asses Ears is an area of about 35 square miles, made up chiefly of white marbles much sheeted and sometimes schistose, which appear as smooth, rounded domes, bare of moss, and therefore affording good footing to the traveler. Long radiating needles of tremolite are not uncommon, but otherwise the limestone is generally almost pure.

Massive limestones occur in a ridge southeast of Kiwalik Mountain and to the south of it in the area north of Koyuk River. Other localities are found just north of the big bend in Koyuk River and in some of the headlands along the shore of Kotzebue Sound, which are the northward continuations of north-south ridges. Black graphitic varieties are not uncommon, especially in the Inmachuk and Goodhope River region.

\section{STRUCTURE.}

The difficulties arising in the attempt to establish the relationships between the various members which have been included in the metamorphic series have been previously enumerated and need only be referred to here; chief among them are the thin but widely extended lava flows and the almost universal covering of moss, which hides the older rocks. However, sufficient reliable observations were made to indicate some of the chief structural features.

A comparison of these observations shows that the strike of the beds over the whole of the mapped area is prevailingly north and south or a little west of north. Overturned folds are not infrequent, but are not the general structural feature. In the western portion the observed dips average between $25^{\circ}$ and $30^{\circ}$, but an increase in the inclination of the beds is noticed as one goes toward the east, so that in the eastern portion the dips average nearly 50. Eastwest strikes are occasionally met, and the dips in such cases are usually low. These observations indicate that the prevailing structural feature of the region consists of a series of open folds, whose axes pitch at low angles either to the north or to the south, 
and that a gradual increase in the intensity of the forces producing folding took place toward the eastern portion of the area, but was not sufficient to produce a general overturning.

The structural characteristics just described are modified at times by the occurrence of an elongated, dome-like or canoe-shaped arrangement of the beds, which interrupts the regularity of the open folding and produces a seeming confusion of strikes and dips. 'This peculiarity was noticed in the vicinity of the massive limestones which appear to underlie the schists and to have been thrust up through them. A most suggestive feature in connection with the occurrence of these limestones is the presence, in a number of cases, of granitic intrusions in their midst, and it is believed that the dome structure may be due, in some instances at least, to the intrusion into the limestones of the granite mass, which made room for itself by an upward displacement of the overlying strata. The erosion of the upper part of the dome has removed the schists, and in some cases enough of the limestones to reveal the central granite core. Such structural features have been observed by Brooks in the southern part of the peninsula.

The beds are at times displaced by faults to an extent not known; most of the examples observed were in less metamorphosed localities of the sedimentary rocks; this, however, is probably due to the fact that in such places faults are more easily distinguished. Faulting was noticed in the banded slates on Hannum Creek. Considerable disturbance of this kind has also taken place in the neighborhood of Trail and Cottonwood creeks, producing much confusion of strikes. Secondary quartz is widely distributed, appearing as veinlets, lenses, and small irregular masses, sometimes developed in the cleavage planes and sometimes cutting them at various angles, and as large veins the presence of which is made known by the broken, angular pieces strewn over the hillside or distributed along the stream channels. In the majority of instances these large veins consist wholly of massive white or bluish quartz, but in some cases they are slightly stained with iron oxide and show some pyrite.

The quartz veins will be referred to again in the discussion of the economic geology of this region.

AGE.

In the absence of evidence based on the finding of organic remains, it is impossible to make any definite statement concerning the age of the schists and limestones of the metamorphic series. This lack is due chiefly to the alteration of the sediments during the process of metamorphism, which destroyed the greater part of whatever fossil remains may have been present, but partly to insufficient time for 
making a systematic search for those which may have escaped destruction.

In the southern part of the peninsula the metamorphic complex was divided by Brooks, ${ }^{a}$ in ascending order, into the Kigluaik, the Kuzitrin, and the Nome series. Of these the Kigluaik and Kuzitrin were believed to be of Paleozoic age and older; the Nome series to be partly Mesozoic, partly Paleozoic. The probability of an unconformity between the Nome series and the underlying rocks was also suggested.

Later field work in the northwestern portion of the peninsula enabled Mr. Collier ${ }^{b}$ to subdivide Mr. Brooks's Nome series into the Port Clarence limestone and the Kugrulk group. The lower of these, the Port Clarence limestone, was definitely determined to be of Ordovician age, while on the basis of paleontologic evidence the Kugruk group was placed in the Silurian. The Port Clarence limestone is typically a massive gray limestone, probably 2,000 feet thick, which covers a large area in the western part of the peninsula. The Kugruk group comprises interstratified limestones, mica-schists, and graphitic schists; it does not include any great thickness of pure limestones, and contains intrusive masses of schistose greenstones. Kugruk fossils gathered by Mr. Collier on Harris Creek during the last summer were determined by Mr. Schuchert to be of Niagaran age, or the middle third of the Silurian. Silurian fossils were also obtained from Baldy Mountain, a few miles southwest of Harris Creek. Observations taken by both Mr. Collier and the writer seem to indicate that the limestones of those localities dip under the schists lying to the eastward and, by increase in the argillaceous matter and decrease of lime, grade into them. It should be stated that sills and dikes of schistose greenstones, which were found by Collier to be well developed in the Kugruk River region, do not appear here, and also that the transition from limestone to schists is not an uninterrupted one, but consists in a series of alternate limestone and schist beds of variable thickness, in which the limestones become more and more impure and at last form only a very unimportant element in the rock exposures. It follows, therefore, that the schists of the Eldorado Creek district are of middle Silurian or later age, and that the underlying massive limestones mentionerl above should probably be correlated with the Harris Creek and Baldy Mountain limestones. No Mesozoic rocks are known on Seward Peninsula, for, in the light of more recent investigations, those localities which were tentatively assigned to the Mesozoic are now known to belong lower down in the time scale.

\footnotetext{
a Brooks, Alfred H., Reconnalssance in the Cape Nome and Norton Bay Reglons, Alaska, in 1900, U. S. Geol. Survey, 1901, p. 27.

${ }^{b}$ Collier, Arthur J., reconnalssance in the northwestern portion of Seward Peninsula, Alaska : Prof. Papel U. S. Geol. Survey No. 2, 1902, p. 18.
} 


\section{UNMETAMORPHOSED SEDIMENTS.}

Sandy and shaly sediments interbedded with thin limestones were noticed at several localities in the valley of Kugruk River, especially in the vicinity of Chicago Creek, where they are associated with deposits of lignitic coal. These beds are folded and much jointerl, but have not been altered to the same degree as have the neighboring schists. They have the same north-south strike and high dips common in the highly metamorphic rocks, and, when weathered, their altered surfaces present an appearance very similar to that which would have resulted had they been burned. Such outcrops were noticed on Kugulu River near the mouth of Chicago Creek and for several miles to the south, also on Chicago Creek one-half mile above the Kugruk. A rather imperfect cleavage was observed at one locality, where the difference in strike of cleavage and bedding amounted to more than $30^{\circ}$. The search for fossils was unsuccessful, and there is a possibility that these beds may be local portions of the old sediments which, for some reason, escaped, to a certain extent, the general alteration; however, in view of the fact that similar deposits are known in other parts of the peninsula, it seems more probable that they are younger than the schists and crystalline limestones. Owing to the scarcity of the outcrops and the fact that the coal beds are not visible on the surface, it proved impossible to determine the relation between them and the coal deposits of Chicago Creek. The bed rock in the vicinity of the slope which has been driven into the coal is entirely covered by moss, and it was not possible to enter the mine owing to the caving of a part of the roof near the entrance.

Other smaller coal deposits are found on French Creek, in the upper valley of the Kngruk; these, however, were not visited. A further description of coal will be found on page 67 of this paper.

Aris.

Unaltered sediments consisting of sandstones, conglomerates, and clay shales were found by Menclenhall in the southern portion of the peninsula, on the Koyuk and also on the Tubutulik, where they contain coal beds and imperfect casts of plant stems, ${ }^{a}$ and were referred by him to the Tertiary. They are folded and, although well indurated, do not resist erosion as successfully as do the schists. They appear to have been deposited in small basins in the older rock.

Extensive deposits consisting chiefly of marine sandstones, and fresh-water deposits containing plant remains, are known along the lower Yukon as far upward as Melozi River and along the Koyukuk as far as Bettles. Associated with these deposits are beds of bitumin-

a Mendenhall, Walter C., Reconnaissance in the Cape Nome and Norton Bay Regions, Alaska, in 1900 . U. S. Geol. Survey, 1901, p. 205. 
ous coal. Doctor Dall gave the name "Nulato" to the sandstones of the lower Yukon and considered them to be of Miocene age. More recent study by Collier, based on fossil determinations by Doctor Knowlton, has, however, shown that the Nulato sandstone, and the fresh-water deposits as well, are of upper Cretaceous age. The marine beds were laid down during an invasion of the sea in a great arm extending inland along the valleys of the Yukon and Koyukuk, as indicated above, and are unconformable to the underlying rocks. There is now no positive evidence to show that any of the sediments of this "Kaltag" series, as it is called by Collier, belong in the Tertiary, although in the light of the present imperfect knowledge it would be unsafe to assume that they do not. Lignite beds, associated with sandstones, shales, and conglomerates, were discovered by Lieut. John C. Cantwell on Kowak River about 75 miles above the mouth, and were referred by Doctor Dall to the Kenai group of the Lower Tertiary. ${ }^{a}$

The investigations of known Alaskan coal deposits made by Dall, Brooks, and Collier have shown that the majority of them occur either in the upper (reatceous or in the Kenai group of the Tertiary, which latter seem to have been laid down in rather isolated basins, chiefly along a continental margin, and never to have formed a continuous deposit over the territory. ${ }^{b}$

It appears, therefore, that in view of the facts presented the coal deposits of the Kugruk Valley, exposed in Chicago and French creeks, may belong either in the upper part of the Cretaceous or in the lower part of the Tertiary, and that without the evidence of organic remains it is not possible to determine definitely to which of the two they should be referred.

It seems fairly certain also that these beds were laid down at the same time as the similar one on the Koyuk and Tubutulik, and that they mark a submergence that did not take place in the western portion of the peninsula, since no corresponding deposits are known there.

IGNEOUS ROCKS.

GENERAL STATEMENT.

The igneous rocks of the region represented on the geologic map accompanying this paper may, for convenience in description, be divided into two general classes. The first includes two groups of rather siliceous rocks; granular intrusives, comprising granites and quartz-diorites, with which are included closely related types inter-

a Dall, W. H., Report on coal and lignite of Alaska: Seventeenth Ann. Rept. U. S. Geol. Survey, pt. 1,1896 , p. 819.

${ }^{b}$ Brooks, Alfred H., The coal resources of Alaska : Twenty-second Ann. Rept. U. S. Geol. Survey, pt. 3. 1902 , p. 537. 


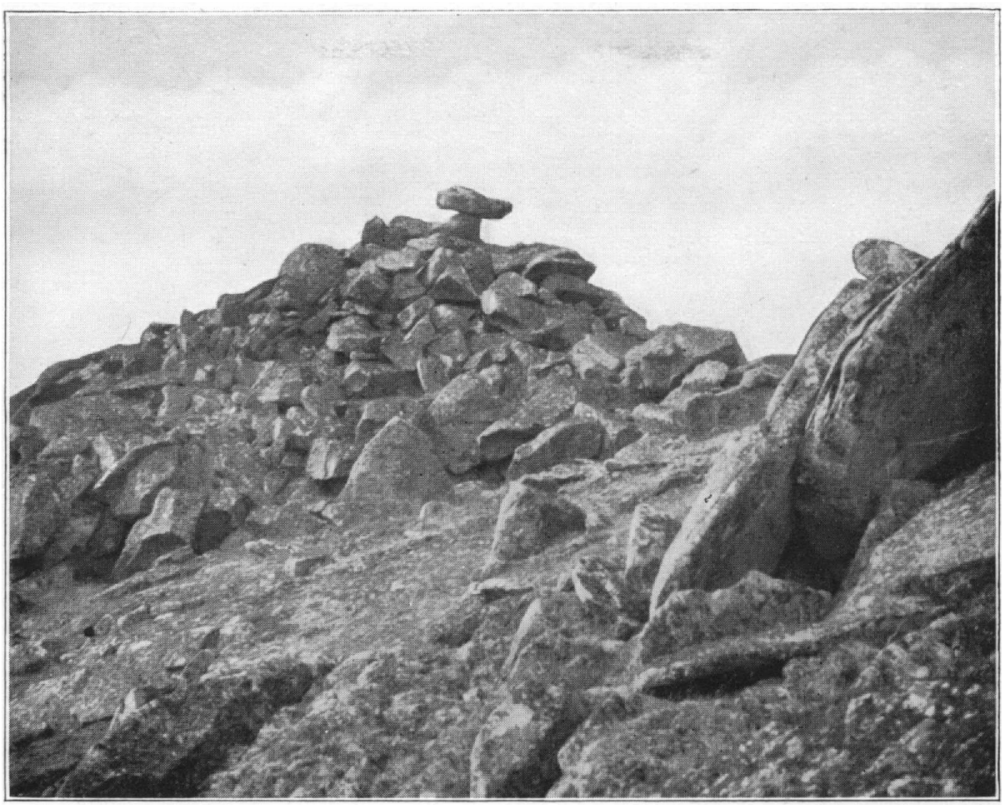

A. WEST CONE OF ASSES EARS, TAKEN FROM A POINT ON EAST CONE 75 FEET FROM THE TOP.

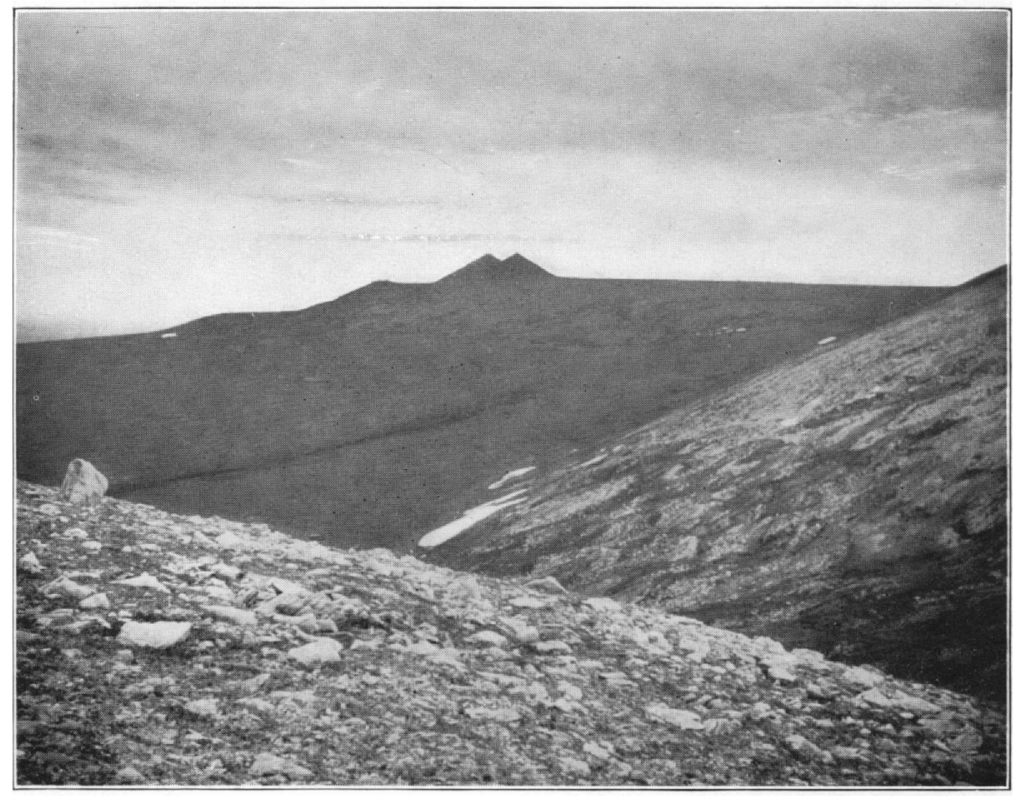

B. ASSES EARS, LOOKING SOUTHEAST; DISTANCE, I MILE. 

mediate in mineralogic composition between the two; and surface effusives, consisting of andesite having a composition similar to that of the diorites. The second class is composed of more basic extrusive rocks, including diabase and basalt.

The granite, diorites, and andesites occur more extensively in the eastern part of the district than elsewhere. The basic rocks, on the other hand, are widespread and appear throughout the entire area. Much the larger part of the greatly dissected mass which forms the divide between the drainages of Kiwalik and Buckland rivers, and contains the highest elevations of the northeastern part of the peninsula, is made up of light-colored granular rocks and andesites, associated, especially toward the outer portions of the area, with basalts and diabases. Dikes and sills of greenstone, such as are seen in the western portion of the peninsula northwest of Nome, were not observed in this region. If such greenstones are present in the area immediately south of Kotzebue Sound they are probably so greatly altered that many of their original peculiarities have been lost, and they are not now readily distinguishable from the including schistose sedimentary rocks. Altered greenstones are present, but so far as observed by the writer they do not have the form of sills or dikes and appear rather as great irregular masses or stocks.

GRANITES AND ASSOCIATED GRANULAR ROCKS.

Under this head are considered a number of different rock types, which are classed together not only because of their like origin, but also because of their similar appearance and close association in the field. They comprise granites, quartz-diorites, and intermediate forms which may properly be classed with the monzonites.

The granites of the central portion of the region have already been referred to in connection with the description of the massive crystalline limestones. 'They do not generally appear as outcrops in an undisturbed condition, but in the form of loose blocks, frequently of considerable size, which are irregilarly bounded by plane surfaces and cover the area in which they occur with a mass of débris thrown down in the greatest confusion. (Pl. IV, $B$, and Pl. V, A.) The best examples of this occurrence were seen in the Asses Ears region. Near the center of the limestone mass is a small granite area, about onehalf a square mile, forming a level stretch between the higher knobs of limestone on the west and the east. A coating of beautiful blue fluorite was observed on a joint face in granite from this locality. The Asses Ears themselves ( $\mathrm{Pl} . \mathrm{V}, B$ ) are two conical heaps of great granite blocks, rising nearly 200 feet above the bench on which they appear to rest. Their elevation, nearly 2,000 feet, and their unusual form make them a conspicuous landmark; they were seen from the 
sound by Kotzebue in 1816, and were given their present name because their "stmmit is in the form of two asses" ears." In area of more than one-half a square mile is here strewn with granite blocks; the rock is gray and has a striking appearance because of its porphyritic character. Twinned crystals of orthoclase feldspar $2 \frac{1}{2}$ to 3 inches in greatest diameter and one-half to three-fourths of an inch thick are not at all infrequent. The dark mineral is largely hornblende. Quartz and plagioclase feldspar are also present. Immediately to the west of the Asses Ears is a hill of limestone. On the east the upper slopes of the Pinnell River drainage basin begin, and no outcrops were seen, but the granite mass appears to be near the boundary of the limestone and schist.

On the west side of Kugruk River, near its junction with Independence Creek, a second area of light-colored granular rock forms an elevated mass reaching a point some 1,600 feet above sea level and extending in a north-south clirection for about $(;$ miles. On both the east and west sides limestones are found, but whether or not the eruptive mass forms the core of a limestone dome the writer did not determine. The rock is of a light-gray color and has an even grain of medium coarseness. While not differing greatly in appearance from the true granites, it has a somewhat unlike mineral composition, resulting from the presence of a considerable amount of plagioclase feldspar in addition to the orthoclase, the two being present in about equal quantities, or with the plagioclase slightly predominating. In thin section the microscope shows plagioclase, orthoclase, hornblende, quartz, and biotite; titanite, apatite, and magnetite are always present. On the basis of the proportionate amounts of plagioclase and orthoclase this rock is classed with the monzonites.

The miscroscopic study of the siliceous schistose rocks of Kiwalik Mountain and the neighboring hills, also of Potato Creek, has led to the conclusion that they also are highly altered granites. The hand specimens show a light-colored, saccharoidal, schistose rock, often slightly stained with iron oxide. In the outer portion of the area the disturbing forces appenr to have had greater effect than near the central part, although the entire mass is highly altered. Under the microscope the rock is seen to contain more quartz than feldspar, with minor quantities of muscovite, biotite, apatite, and zircon in grains or rarely in crystals; secondary calcite is rather frequent. The weathered outcrops present the same characteristic appearance as the other granites mentioned. The mountain is covered with a confused mass of angular blocks which extend down the slopes like huge streams and are everywhere covered with a thick growth of black lichens.

In the western part of the area the granites of the Hot Springs region, in the ridge extending northward from Midnight Mountain to 
Devil Mountain, were examined by Collicl" and are reported to be similar in general type to the porphyritic biotite-granites which occur still farther west at Ear Mountain.

Turning now to the eastern side of the mapped area, it will be remembered that the high ridge between Buckland and Kiwalik rivers has been referred to as a great eruptive complex in which are to be found representatives of all the igneous rocks occurring south of Kotzebue Sound. This ridge extends from Eschischoltz Bay south to Koyuk River, and forms a boundary line between Seward Peninsula and the mainland of Alaska on the east. In the central and southern part of the ridge elevations of more than 2,500 feet are reached. The writer was not able to study a section extending all the way from the Kiwalik to the Buckland, since it was too late in the seatson at the time of his visit to the region; but in crossing the main part of the mass from the west ward, a fter leaving the higinly metamorphic rock of the Kiwalik Valley, one meets first with basic rocks of the basaltic and diabasic types, followed by andesites, which are well developed and form a large part of the riclge; finally, in the central portion of the complex and forming a core for the whole are discontinuous areas of more siliceous rocks, including a number of clifferent varietiesgranites, monzonites, and quartz-diorites. Hormblende is the prevailing dark mineral of the granites, but at times biotite takes its place. By a decrease in the amount of quartz the granites approach syenites in composition. such phases being characterized by the abundance and large size of orthoclase crystals, which usually show Carlsbar twinning and have a roughly parallel arrangement, with the small intervening spaces filled with hornblende, biotite, and a small amount of quartz. Titanite is abundant.

An unusual and highly interesting type was observed in the most southerly area of the granular rocks. 'The hand specimen shows a dark-gray rock composed of abundant large, tabular feldspar crystals with a small amount of dark greenish. fine-grained filling. In thin section the rock is seen to consist of large crystals of orthoclase feldspar with a microscopic intergrow th of parallel plagioclase plates, embedded in a groundmass of agirine, augite, melanite, and small scattered plagioclases. The three last-named minerals fill spacess between the large orthoclase crystals, which are very subordinate in volume to the spaces occupied by the crystals themselves. Titanite and apatite are present, and a cloudy zeolitic decomposition product appears at times. The rock corresponds very closely in appearance and composition with the garnet pyroxene malignites which Lawson has described from Maligne River in Ontario.

"Collier, Arthur J., A reconnaissance in the northwestern portion of Seward Peninsula,

- Alaska : Prof. Paper C. S. Geol. Survey No. 2, 1902, p. 30. 
The diorites present no unusual features. They are nearly always of a light-grayish color, and are sometimes prophyritic. The prevailing feldspar is plagioclase with zonal structure. Some quartz is always present, and the dark mineral is usually hornblende, but at times biotite. In one or two instances a well-developed flow structure was seen in large blocks of the diorite which were cut by small granitic or aplitic dikes, largely feldspar.

Monzonites, intermediate in composition between granites and quartz-diorites, are frequent. Orthoclase and plagioclase predominate, while hornblende, biotite, and quartz are present; also titanite, magnetite, apatite, and occasionally zircon. All the granular rocks of this region are abundantly supplied with titanite, which may often be easily seen in the hand specimen, and is very noticeable under the microscope.

Viewed as a whole, the feature of the granular rocks which most strongly draws attention in the field is their porphyritic structure and their characteristic mode of weathering.

Age.-The age of the granular rocks has not yet been definitely established. They are evidently younger than the sedimentary formations into which they are intruded and older than the coal-bearing beds overlying the schists. The granites of the southern and western parts of the peninsula were tentatively placed in the Mesozoic by Mendenhall and Collier in the belief that part of the metamorphic sediments which they intruded were of that age. More recent investigation by Collier has shown that there is as yet no evidence to indicate that any of the metamorphic rocks of Seward Peninsula are of later age than lower Carboniferous. He has furthermore shown the possibility, if not the probability, that the coal beds were laid down in Cretaceous time rather than Tertiary.

Inasmuch as these granites are similar in their occurrence to the granites and associated granular rocks of the northeastern part of the peninsula, it seems probable that they are of approximately the same age, but it is evident from the facts presented that the range of time during which they may have been intruded is very great, extending from the Carboniferous to the Cretaceous or Tertiary, and that our present knowledge is not sufficient to fix their age definitely.

ANDESITES.

Andesites are abundant in the Kiwalik-Buckland divide and are probably the surface representatives of an igneous magma corresponding in composition to the deep-seated diorites and monzonites. As already stated, they occupy, where observed by the writer, a position intermediate between the basic rocks of the western side of the ridge and the central acid ones, and form a large part of the 


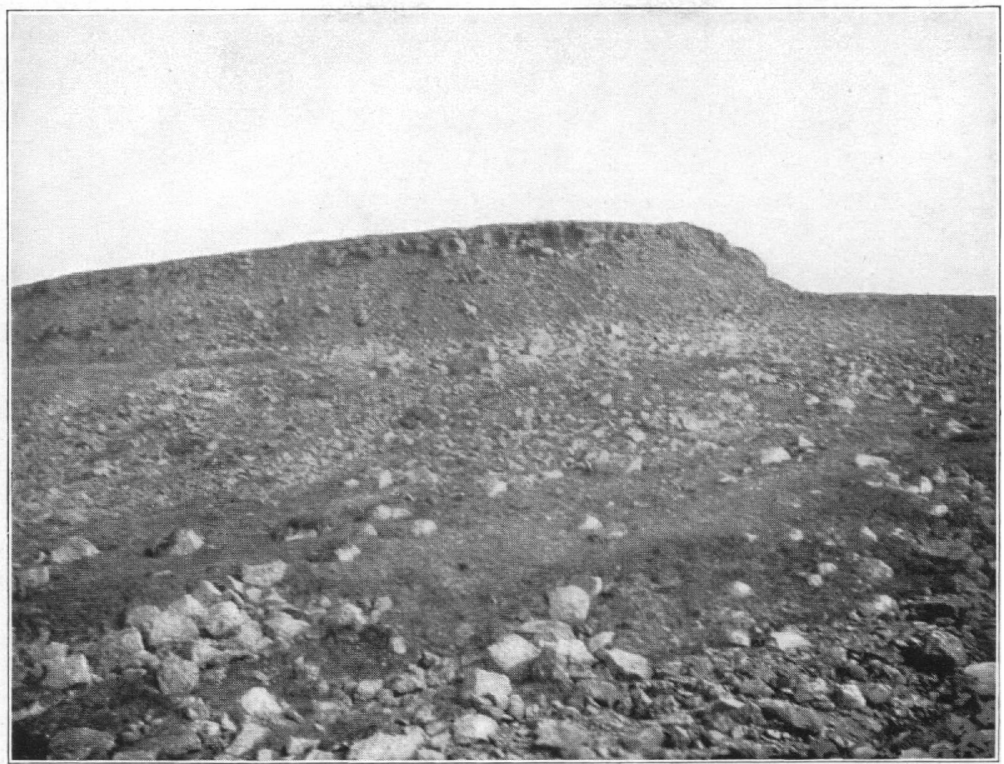

A. LAVA FLOW ON COTTONWOOD CREEK

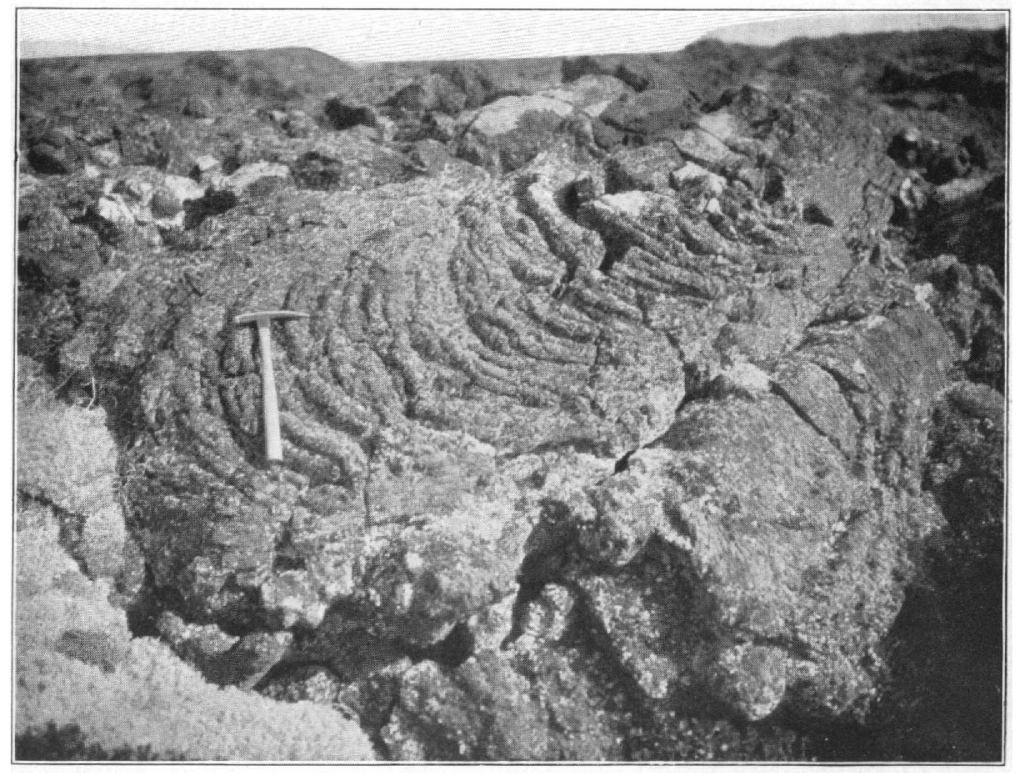

B. ROPY SURFACE OF RECENT LAVA FLOW BETWEEN THE FORKS OF KUZITRIN RIVER 

watershed. They are of a dark-gray or greenish color, and on an exposed surface have a spotted appearance, due to the alteration of the feldspar phenocrysts. Both hornblende and pyroxene varieties were seen, the latter containing considerable olivine in addition to pyroxene and showing the secondary mineral, iddingsite. Alteration of pyroxene to hornblende was also observed. The feldspar is a basic variety, labradorite or sometimes anorthite, giving as alteration products chlorite and epidote.

Andesite breccias were found at various localities.

As to the age of the andesites, it can only be said that they, too, are younger than the metamorphic rocks, but whether earlier or later than the granites is not yet known.

\section{BASAL'IS.}

The recent lava flows of the central and eastern portion of Seward Peninsula were first mentioned in the reports of Mendenhall and Collier for 1900 and 1901, although the presence of such flows was previously known to prospectors, who, pushing outward from the Nome country, entered the region in search of placer gold.

It is evident from an examination of the different localities where the lavas appear that the flows did not all take place at the same time and that those in the upper Kuzitrin Valley, described by Collier, are more recent than those occurring to the northeast. The flows will therefore be spoken of as older flows and more recent flows. A glance at the map will show the distribution, and it need only be added that the more recent eruptions are confiner to the region south and southwest of Lake Imuruk.

In color the lavas are dark gray, green, or nearly black; they are usually very cellular or even spongy in appearance, but at times compact and without the amygdaloidal cavities. Outcrops of the older lavas in place are not plentiful, and the edges of the sheets, where cut through by the streams, are marked by tumbled heaps of blocks resulting from the jointed columnar structure of the lava. In a few places they form flat-topped hills or mesas from 20 to 50 feet high (Pl. VI, $\dot{A}$ ), very conspicuous when viewed from a distance and evidently the remains of a partly eroded sheet. Agglomerates and breccias were observed at several points. $A$ study of the numerous specimens collected shows them to be made up of diabases and basalts, both rich in olivine. In the basalts, especially, olivine phenocrysts are abundant and very noticeable, even in the hand specimen. Iddingsite is not infrequent as an alteration product of the olivines.

That a succession of outbreaks of the lava has taken place is shown in a number of places, but probably most plainly in the region about the head of Kuzitrin River, where positive evidence is afforded in 
the terraced condition of the different flows, three distinct benches occurring in one locality.

In this region the outpouring of liquid rock took place in not very distant time, for the ropy surface (Pl. VI, B) and irregular margin are still preserved, just as at the time when the molten strean ceased to flow. Caverns or tumels, produced by the cooling of the surface and subsequent outflow of the still liquid rock beneath, are nunierous. They show a height of 20 to 25 feet and a width in some instances as great as 200 or 300 feet, but rarely have the roofs preserved to the present time, since the weight was too great for an arch of such width (Pl. VII, A). Flattened lenticular steam cavities, 2 to 3 feet in greatest dianeter, are sometimes exposed, and the upper surface of the sheet is marked here and there by smooth, irregular elevations produced by the escape of steam and the welling up of the lava from below.

Inportant modifications of the drainage were lorought about by the extrusion of the lava, which occupied the depressions and flowed down the valleys in broal rivers of molten rock. At times the cooling of the advancing front wall dammed back the flow and forced it over the low, rounded divides (Pl. VII, B) between the watercourses into the next valley beyond, or formed a lake which finally overflowed the obstruction and resined its original course, only to repeat the process a little farther on.

In this way islands of bare ground were left between the great finger-like protrusions along the edge of the sheet. It the same time a shifting of the watercourses was brought about, for when not of sufficient volume to fill it the lava occupied the lowest part of the valley and the waters sought a new channel parallel to the old one, along the edge of the hardened flow. A number of lakes and ponds also owe their existence to the damming of streams by lava, among which may be mentioned Lake Imuruk, the largest body of fresh water on the peninsula.

Observations made by Collier on Noxapaga River showed these more recent lavas overlying gravels which are cemented near the contact by indurated clays and contain pebbles of an older flow-conclusive evidence that considerable time must have elapsed between the first ontbreaks and the solidification of the flows just described. The source from which the recent basalts of Noxapaga and Kuzitrin rivers were discharged lies to the southwest of Lake Imuruk, this being shown by the scattered lava cones as well as by the direction of movement of the flows themselves.

On the upper part of Koyuk River a similar relation of basalts and gravels was observed by Mendenhall. He found on the truncated edges of the schists 5 feet of gravel, made up of schist, vein quartz, and granite; this in turn was covered by an undisturbed hor- 


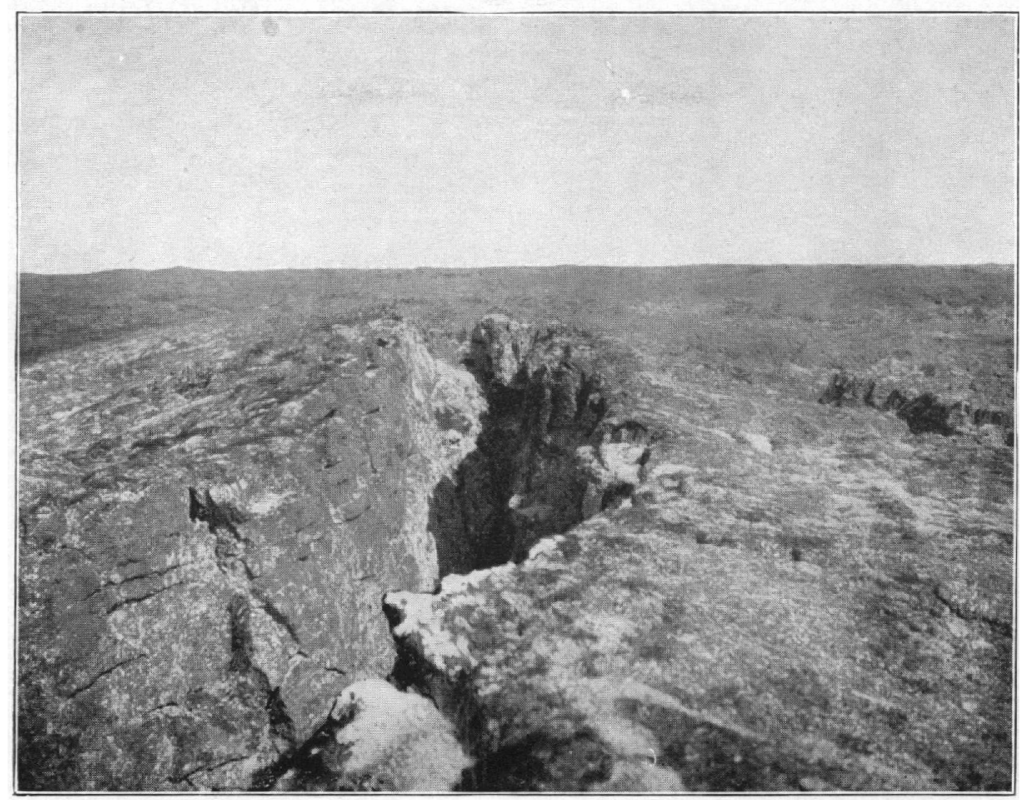

A. FISSURE IN RECENT LAVAS BETWEEN THE FORKS OF KUZITRIN RIVER, CAUSEO BY THE SINKING OF THE HARDENED SURFACE AFTER THE MOLTEN LAVA BELOW HAD FLOWED OUJT FROM EITHER SIDE.

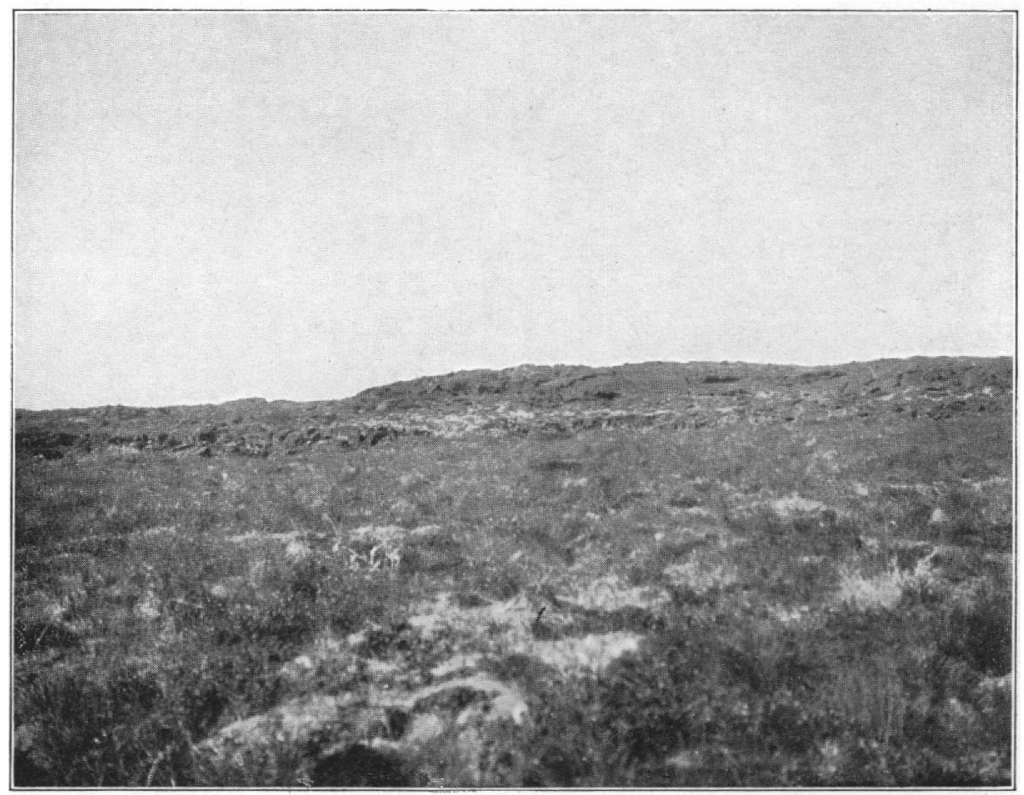

b. RECENT LAVA FLOW BETWEEN THE FORKS OF THE KUZITRIN 

izontal sheet of olivine-basalt, which had been but little affected by the erosive action of the stream since it came to rest, and was therefore believed by him to be of Pleistocene age.

No evidence of flows as recent as those between Noxapaga and Kuritrin rivers was seen by the writer in the country toward the northeast, where the lavas have been subjected to weathering for a much longer time and have suffered correspondingly. In the region south of Kotzebue Sound it is probable that a drainage system differing very little from the present one and containing a considerable body of gravels was invaded and partly filled by the basic lavas, which formed a sheet of no great thickness across the valleys. The present streams then resumed their work and cut down through the thin lava sheet, uncovered again the older channels, and left the conspicuous rim of lava now seen surrounding many of the valleys. In evidence of this may be mentioned the fact that the lavas in almost all cases appear well up on the sides of the narrow valleys, and that there is no indication that they ever covered the higher hills above the valleys. (See fig. 2 and Pl. VIII, A.) In one instance, at the west end

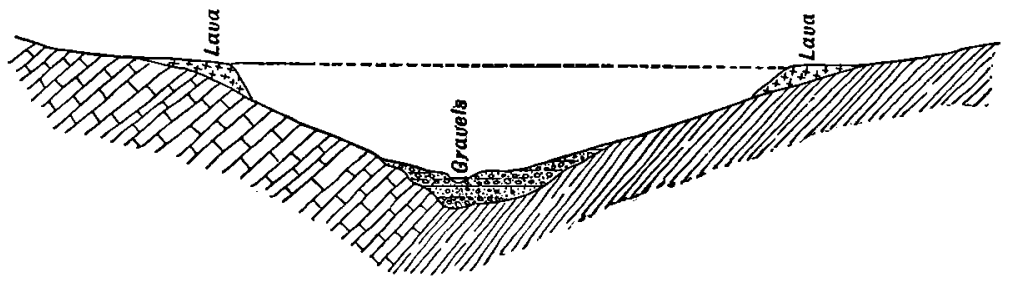

FIG. 2.-Dlagrammatic sketch showing the occurrence of lava flows in some of the valleys south of Kotzebue Sound.

of the big bend of Kugruk River, the lavas appear at the water's edge; in all other cases, as far as observed by the writer, they are above the streams, which at present occupy channels in the older metamorphic schists and limestones. It should be stated, however, that no contact of lavas overlying gravels, such as that described by Mendenhall and Collier, was observed in the region, since the great quantity of broken blocks, thrown down largely by the action of the frost, prevented a view of the base of the flows. This condition also prevented any accurate determination of the thickness of the lava, though two flat-topped hills of it south of the upper part of Cottonwood Creek have an elevation of 60 feet above the plain on which they rest. In the one nearer the Cottonwood the base is formed by some 8 feet of agglomerate containing bowlders of basalt. This relation of the lavas to the gravels is a question of some interest, since, if the ideas here advanced are correct, it is possible that valuable placer gravels may be present somewhere beneath the lavas.

Bull. 247-05 $\mathrm{M}-3$ 
The basalts and diabases of the area east of Kiwalik River are somewhat different in occurrence from those previously described, in that they are found at considerably higher elevations and apparently are not directly connected with those of the more western area. The hills facing Kiwalik River on the east are largely made up of lavas in which the diabases predominate over the basalts. Sheeted flows do not occur frequently, and under the microscope the rock is seen at times to be somewhat altered. Prospectors report that the lavas extend as far eastward as Buckland River.

Age.-The evidence for the age of the lavas, as found by Messrs. Mendenhall and Collier in the valleys of Koyuk, Kuzitrin, and Noxapaga rivers, has already been presented and will only be referred to here. The recent origin of the flows in that region is shown by their surface appearance, by the fact that they have been only slightly affected by frost, water, etc., and, further, by the occurrence of flows overlying unconsolidated gravels which differ in no respect from the gravel deposits of the Koyuk Valley and the upper Kuzitrin lowlands. In both instances the flows are considered to be of Pleistocene or late Pliocene age. It would seem, then, that the time when the volcanic disturbances ceased can be determined with a fair degree of accuracy. The age of the older flows, however, presents a problem whose solution is more difficult and has not yet been satisfactorily reached. The lowest possible age limit is fixed by the coal-bearing beds, whose age is uncertain. There can be little question that the lavas nearer Kotzebue Sound are older than those on the south, and it is most probable that the volcanic activity extended over a considerable portion of the Pleistocene at least, beginning after the coal beds were folded and eroded and ending only in comparatively recent geologic time. This is certainly the case if the high lavas of the Kiwalik-Buckland watershed ever formed an extended sheet over that region and are to be connected with the lower flows to the westward, since they have been subject to erosion for a very long time.

In this connection the lava flows of the lower Yulon and of St. Michael Island are of interest. Spurr has described their occurrence near the mouth of the Koyukuk ${ }^{a}$ and has shown that St. Michael Island is made up of interbedded lava flows and water-laid materials consisting of clays and scoriaceous lava. The craters from which the lavas of the latter locality flowed are plainly shown. The flows themselves are vesicular, still retaining the original wrinkled or ropy surface. From data collected by himself and others Spurr concluded that the flows of St. Michael, which he held at that time to be nearly contemporaneous in age with those of the Koyukuk, may have begun in the late Miocene and continued into the early part of

a Spuri, J. E, Geology of the Yukon gold district, Alaska: Eighteenth Ann. Rept. U. S. Geol. Survey, pt. 3, 1898, pp. 244 et seq. 


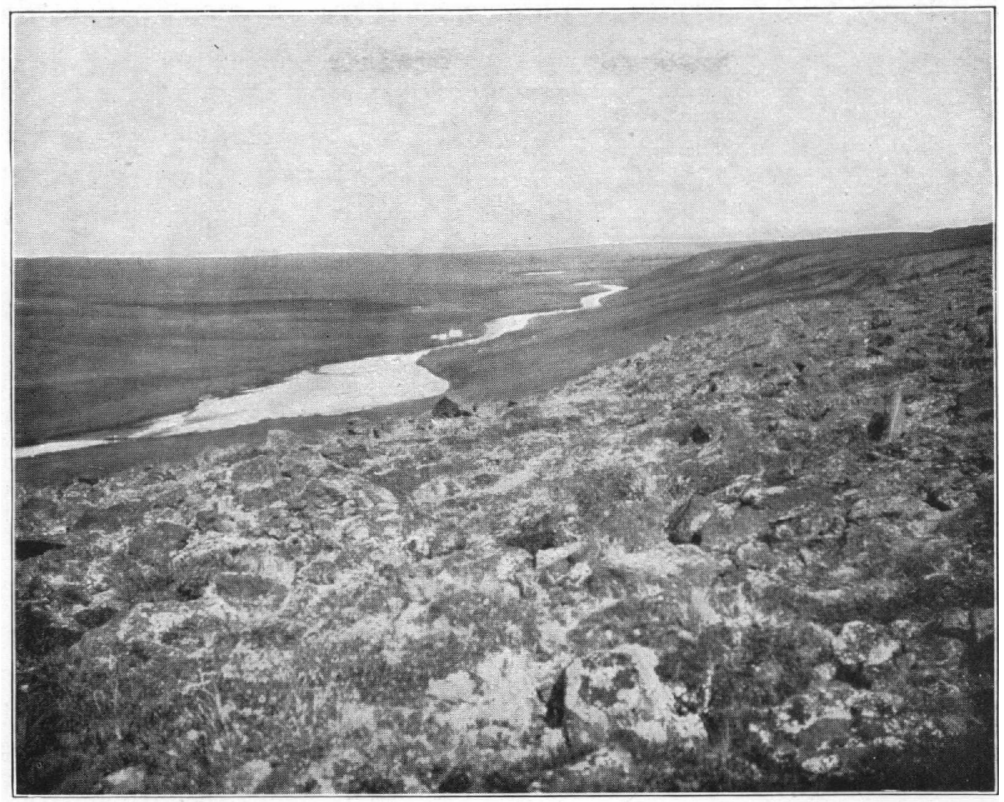

A. LAVA RIM ON THE LOWER INMACHUK.

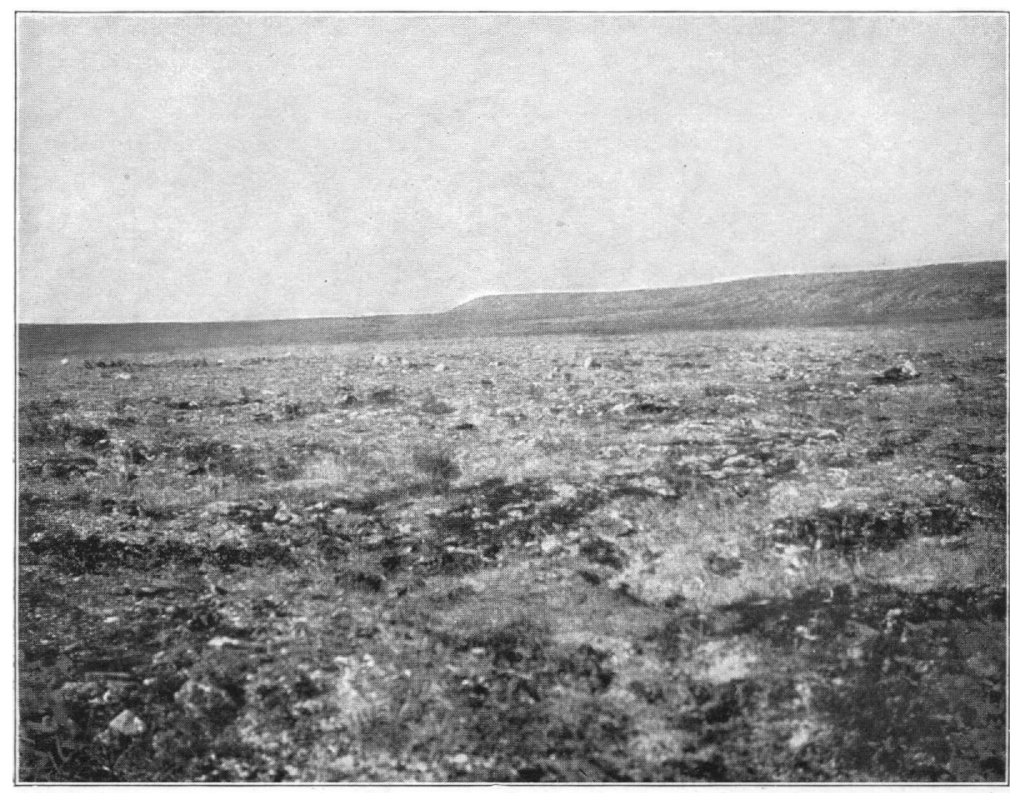

B. TERRACED GRANITES EAST OF KIWALIK RIVER. 

the. Pleistocene, and that the period of greatest activity was postMiocene. This conclusion concerning the Koyukuk locality was based on the supposed Miocene age of the "Nulato" sandstones and associated beds. It has already been stated, however, that the "Nulato" sandstones are now known to have been deposited in Cretaceous time, so that the lower limit for the age of the lavas has receded in the time scale.

It may further be said that many of the islands of Bering Sea are built up largely of recent lavas, and that volcanic activity has by no means entirely ceased, as is seen in the formation of the islands Bogoslof and Grewingk in 1796 and 1883, respectively.

\section{DYNAMIC HISTORY.}

Two major periods of deformation are now recognized as having occurred in Seward Peninsula, but the exact times of the movements are still in doubt.

In the southern and western portions the oldest formations affected by the disturbing forces are of Silurian or possibly of pre-Silurian age. These formations now appear as schists and altered limestones containing sills or interbedded flows of greenstone. There is evidence to show that the greenstones are derived from basic igneous rocks, part of which were intruded into the sedimentaries as true sills and the remainder poured out on the surface and subsequently buried by the deposition of younger material upon them. In their present condition, however, the distinction is often hard to make. In one place - at Cape Mountain, in the extreme western part of the peninsula-the Silurian sediments are overlain by a small area of limestones and interbedded schists of doubtful Devonian or Carboniferous age, but there is no other evidence to indicate that any of the metamorphic rocks of Seward Peninsula are younger than Silurian.

This complex, both sedimentary and igneous in origin, was affected by the two movements mentioned, which acted in very different directions. One produced a structure in which the axes of folds extend in an east-west direction, and is most plainly expressed in the uplift constituting the Kigluaik and Bendeleben mountains. It was accompanied by intrusions of granite, mostly in the form of sills, which are frequent in these mountain masses. This east-west structure corresponds in the direction of its folds with the main structural lines of the whole of western Alaska and is believed to have been produced before the deposition of the coal beds; that is, before Cretaceous or lower Tertiary time.

The second movement resulted in the production of folds whose axes have a general north-south direction and are the dominant struetural feature of the northern portion of the peninsula. This movement, which was probably accompanied by granite intrusions also, 
was begun before the deposition of the coal beds and continued for an indefinite period after they were laid down.

Turning now to the northeastern portion of the peninsula in particular, the first recognizable movement to affect the other sedimentary rocks appears to have been the intrusion of certain granite masses, which are best represented in Kiwalik Mountain and its vicinity. The evidence for this statement is found in the highly altered condition of these granites as compared with other granular cruptive rocks of the region. From the similarity in appearance and alteration of the Kiwalik Mountain mass and the sheared granites south of Koyuk River it is suggested that these two may be of the same age; in other words, that they are to be connected with the older of the great mountain-making periods.

After the uplift of the Kigluaik and Bendeleben mountains there began a series of movements, varying locally in their intensity, which gave to the first granite intrusions their schistose character and initiated the north-south folding in the older sedimentary rocks. This movement began before and was not completed till long after the deposition of the coal-bearing formation, since the coal beds and their accompanying sediments overlie the older sediments unconformably, but with the same strike, and are themselves strongly folded. This movement was probably accompanied late in its history by the intrusion of the later granite dikes found cutting the older sills of the Bendeleben Mountains and of the granular igneous rocks of the Kiwalik-Buckland divide, which do not possess the schistose structure of the Kiwalik Mountain area and have been altered only through the process of weathering and whatever forces produced the joint structure. Reasons have already been given for considering the structure of the schists and the limestones as being connected in some way with the presence of the granular rocks. It was shown that the axes of folds of the metamorphic sedimentary rocks are parallel to the trend of the eruptive mass, and that in going from the western to the eastern borders of the mapped area the closeness of folding increases-an observation which is confirmed by the conditions met by Collier in the northwestern portion of the peninsula, where the northsouth folding, which has its maximum development in the Harris Dome-Midnight Mountain region, gradually decreases toward the west and finally dies out altogether.

The uplift of the Darby Mountains in the sonthern part of the peninsula and the extensive granite intrusions which accompanied it are a further expression of the second great period of dynamic activity. If the facts presented have been correctly interpreted, this last movement began in pre-Cretaceous or pre-Tertiary time and continued for an unknown period, possibly being interrupted for a time during the deposition of the younger sediments. It was followed by 
uplift and a long erosion interval, dhring which the then existing land mass was reduced almost to a plain and the chief features of the topography as we see it now were determined. The latest records of disturbance are found in the lava flows of the central region and the evidences of changes in elevation which appear to be going on at the present tince. There is also reason for thinking that some slight movement acting in a north-sonth direction took place in pre-Pleistocene time and resulted in the formation of the Kuzitrin basin, now filled with Pleistocene gravels.

In conclusion, it should be said that the dynamic history of Seward Peninsula is not fully understood and can not be until more detailed investigation shall have greatly increased our knowledge of the facts relating to it.

\section{SURFICIAL DEPOSITS.}

GENERAL STATEMENT.

Gravels and silts produced by weathering of the bed rock, brought about in great measure by the destructive power of frosts and the grinding of water currents, make up one of the most widely distributed geologic formations to be seen on the whole peninsula. These deposits are found on all the streams, forming the broad, flat bottom lands of the larger rivers and covering the floors of the narrow canyons cut by the smaller creeks. Far more extensive still are the gravels of the low-lying coastal plains into which the valley floors merge and which form one of the most noticeable features of the northern half of the peninsula.

In the description of the geology of the southern part of Seward Peninsula the surficial deposits were divided into four groups. Brooks says: ${ }^{a}$ "The first group includes the deposits of the present rivers, streams, and sea beaches. The second group includes marine and river terraces and the coastal plain sediments. The third group is made up of the glacial deposits, which are limited to a few mountain ranges. As a fourth group we have the ground ice and the residual soil."

The classification just given will be followed in this paper with a single change. Since in the region studied the ground ice is of considerable extent and is not necessarily connected with residual soils, the last-named group is divided into two divisions, one including the residual soils, the other the ground ice.

From an economic standpoint the first two groups, and especially the first, are of greatest interest, since it is in these that the known placer-gold deposits are located; the three remaining groups are of

"Brooks, Alfred H., Reconnaissance in the Cape Nome and Norton Bay Regions, Alaska, in 1900, U. S. Geol. Survey, 1901, p. 12. 
importance principally in a scientific way and through their connection with the other two.

STREAM AND BEACH GRAVELS.

The deposits of the present stream valleys are made up of material which in all cases may be referred to a local source within the present drainage basin and which contains fragments, both coarse and fine, waterworn and angular, derived from the neighboring country rock. The deposits are without any regular arrangement, or they may be more or less regularly stratified, but it is not usual for a stratum to be continuous for any considerable distance. A bed of fine silt or muck is always present on the gravels when not cut through by the streams, and frequently a bed of ice of variable thickness, up to 20 feet or more, is present under the silt. The silt and moss together usually have a thickness of 2 to 3 feet; less often, a thickness of 8 to 10 feet.

In general it may be said that the fragments decrease in average size and angularity and are more smoothly worn in the larger streams, so that sands and fine rounded gravels are there more frequently met with. This is doubtless dne to the greater distance traveled and the longer period through which the particles have been ground together by the water currents.

The gravels are often much modified in composition and disturbed in their arrangement by the sloughing off of muck and moss from the banks of the streams, by slides from the hill slopes, and in the springtime by the presence of ice masses, which have an important influence in causing changes in the stream channels and in determining the places where the débris brought down by the high waters of the spring thaw shall be deposited.

The gravels of the first group will be more fully described in connection with the placer-gold deposits.

The beach gravels of Kotzebue Sound, including the gravels within reach of wave action at present, show a greater variety of fragments than is usual in the case of any one of the stream deposits, but, as far as observed, the greater part of the material can be referred to a source within the influence of the adjacent streams. Beach gravels are sorted and laid down with greater regularity than is seen in the stream valleys. Much of the beach material along the south shore is derived from the headlands against which the waves now beat, but in the east and southeast part of the sound the waters are working on material brought down by several large streams, as Noatak, Kowak, Selawik, Buckland, and Kiwalik rivers, which deposit their loads in that vicinity. 
The second group of deposits, which includes marine and river terraces and the coastal plain sediments, is most extensively represented in the flat lands bordering the Arctic Ocean and Kotzebue Sound on either side of Devil Momntain ridge. This coastal plain occupies the entire Arctic slope of the peninsula from Cape Prince of Wales to Cape Espenberg. At Cape Espenberg it turns to the south and includes the whole of the Goodhope Bay slope; on the south sicle of Goodhope Bay and Kotzebue Sound the plain extends inland along the lower valleys of the rivers, but its continuity is broken by the north-south ridges, whose northward extensions form the headlands along the shore. The greatest width reached by the coastal plain, about 30 miles, is in the valley of Serpentine River, in which the deposits occupy an embayment, triangular in shape, bounded on the east by the Midnight-Devil Mountain divide and on the south by the watershed separating the drainage into Bering Sea from that into the Arctic Ocean. In 1901 Collier found that at its southern boundary this plain reached an elevation of about 200 feet above sea level and sloped gradually northward to the sea. Extending from Bering Strait to within 35 miles of Cape Espenberg is a line of sand barriers inclosing a series of lagoons, the largest of which is Shishmaref Inlet. These barriers are broken through occasionally, affording outlets for the Arctic drainage.

The Goodhope Bay coastal plain, which has an average width of about 15 miles, lacks the barrier beaches and, consequently, the lagoons. The gravels which form the plain are rarely to be seen, since even in the case of the larger streams the steep banks are composed entirely of the silts which cover the whole of the lowlands.

Eastward from Goodhope River the coustal plain gravels are continued into the river valleys, where they form narrow deposits extending inland for considerable distances. Along the lower part of Kiwalik River the caving of the banks in one or two localities show well-stratified gravels, containing a large amount of fine material, overlain by muck. Spafarief Bay, into which Kiwalik River flows, is surrounded by steep banks of the coastal plain gravels, apparently laid down in a submerged valley and since raised to their present elevation.

The existence of elevated marine or river terraces is not so well shown in the northeastern part of the peninsula as in the western and southwestern. Well-developed benches were seen in only a few places, the best evidence of their former presence being found in the deposits of gravel which occur well up on the hills, above the present stream gravels. They are known to the prospectors as wash gravel, and contain a much larger percentage of rounded quartz pebbles 
than do the stream deposits. Wash gravel was exposed by holes put down to bed rock in Candle Creek Valley and on Old Glory and Perry creeks. Elevated gravel benches were seen on some of the upper tributaries of the Kiwalik and on Old Glory Creek at an altitude of about 500 or 600 feet above sea level.

\section{GIACIAL DEPOSITS.}

The fact that Seward Peninsula has not been subjected to regional glaciation is now too well established to require further proof, and it need only be stated that all the evidence gathered during the field work of the last season only tends to confirm the conclusions reached by former writers; the absence of the characteristic deposits and of glacial striæ, and the frequent occurrence of rock pinnacles projecting through residual soil, are noteworthy.

Furthermore, no definite proof of local glaciation was found, such as is seen in the terminal moraines, with their kettle holes and transported bowlders, the broad U-shaped valleys, and the glacial cirques of the Salmon Lake Valley and the Kigluaik Mountains. It was thought that such evidence of local glaciation might be discovered in the high hills of the Kiwalik-Buckland divide, and in one or two instances narrow valleys with steep sides and rounded bottoms were noticed, but morainal deposits did not appear, and any glacial ice which may have formerly occupied such localities must have been of very limited extent. Nearly all the valleys are noticeably $V$-shaped, very narrow, and their steep sides are strewn with débris from the upper slopes.

\section{RESIDUAL SOIL.}

Residual soils include the materials resulting from the weathering of rock in place, and consequently the character of such soils depends on the composition of the rock. Owing to the presence of the moss the soil on bed rock is rarely seen, except on the tops of ridges, and since the conditions for observation are unfavorable no special attention was given them.

\section{GROUND ICE.}

Reference has previously been made to the ice beds which were seen overlying the gravel deposits of the creeks and rivers. Such beds were found in the bottoms of nearly all the valleys where the working of placer gravels gave an opportunity to observe them or where the streams had recently cut a new channel through the muck. Exposures of this kind are not permanent, since the melting of the ice front is followed by a falling of the overlying muck and moss, which cover the ice and thus protect it from further thawing. The ice varies in thickness from a foot to 20 feet or more. Extensive ice 
beds may be sees along the lower portion of Inmachuk River, on Candle Creek, and along Kiwalik River. On the Kiwalk, ice beds from 15 to 20 feet thick were seen in several places at an elevation of 200 feet above sea level; the ice was solid and clear, except on the surface, where the water from the tundra had covered it with a thin coating of mud.

The best known and most extensive ice beds of Seward Peninsula are located at Elephant Point, Eschscholtz Bay. They were discovered by Kotzebue in 1816, and have since been visited by Beechey, Dall, and others, by whom they have been described, the most recent account being that of Dall. ${ }^{a}$

The ice beds-for there appear to be two at Elephant Point, one above the other-are overlain by clay, containing the remains of Pleistocene mammals, and covered by a good growth of dwarf birches and herbage.

The greatest depth of frost on Seward Peninsula is not known. Near Nome the frozen gravels, in one or two cases, have been passed at a depth of about 90 feet, while other shafts of greater depth did not reach thawed ground. On Chicago Creek, near Kugruk River, a depth considerably greater was reached without discovering the limit of the frost, which seems to depend largely on the efficiency of the drainage.

\section{MAMMALIAN REMAINS.}

Teeth and portions of tusks of the mammoth are found in the valley deposits and on the gravel bars of the streams. The writer does not know of any discovery of a complete skeleton in the region, although reports of that kind are often heard, and the remains are so numerous as to lead one to expect that a whole one may possibly be found. The remains are known on all the larger streams; they are usually contained in the muck overlying the gravels, and are exposed by the cutting of streams and the caving of the banks. In this way the several portions of a skeleton are widely scattered and the finding of all the members is made more difficult. In some cases it may be that the animals were mired in bogs where now found, but it is also possible that the remains have been washed to their present location in the muck from some other point. Infrequently portions of a skeleton are exposed on the surface; such a case was seen by members of the Survey party during the summer in the Goodhope Bay region, where two large tusks, badly decayed, were only partly concealed by the moss. A large pair of tusks was on exhibition at Kiwalik during the early part of the season. Teeth and a considerable portion of a skeleton were found by prospectors on Inma-

a Dall, W. H., Coal and lignites of Alaska: Seventeenth Ann. IRept. U. S. Geol. Survey. pt. 1,1896 , pp. $850-855$. 
chuk River, and portions of tusks were picked up by the writer on Kugruk River. Prospectors report numerous remains on the Buckland, of both the mammoth and the musk ox.

Elephant Point, on Eschscholtz Bay, was so named from the abundance of mammoth remains contained in the clays which overlie the ground ice. Eight species of mammals from the clays have been reported by Dall."

In the early part of the season two Laplanders, prospecting on Quartz Creek, a tributary to Kiwalik River, uncovered the skull of a musk ox, which lay near bed rock beneath 8 feet of gravels. A similar skull was found on Bear Creek, a tributary to Buckland River.

\section{DEVELOPMENT OF TOPOGRAPHY.}

INTRODUCTION.

The study of the general surface features of Alaska has led to the recognition of four well-marked geographic provinces, ${ }^{b}$ which, named from south to north, are as follows: The Pacific mountain system, including the numerous nearly parallel mountain ranges adjacent to the Pacific along the whole southern coast of Alaska; the central plateau region, a broad central zone whose axis is followed by Yukon River and which includes the drainage of the greater part of Alaska and the Yukon Territory; the Rocky Mountain system, including several mountain ranges and forming the westward continuation of the Rocky Mountains of the United States and Canada; and, finally, the Arctic slope region, including the greater part of Alaska north of the latitude of Cape Lisburne, or, more accurately, all the region north of the Rocky Mountains.

Seward Peninsula lies in the northern part of what is probably the west continuation of the central plateau region, which may be described as a rolling upland deeply dissected by numerous watercourses, whose flat-topped, interstream areas stand at one general level and mark the surface of an ancient plain now elevated in its eastern portion to a height of some 3,500 feet above sea level, and, in Alaska, sloping gently west toward Bering Sea.

In that portion of the peninsula studied by the writer three prominent topographic features are strongly marked: First, the broadtopped, rounded hills, remnants of a much-dissected plain that has been partly destroyed by stream erosion and is well seen in the region between the Midnight Mountain ridge and Kiwalik River; second, the succession of finely developed rock terraces, or benches,

a Dall, W. H., Coal and lignites of Alaska: Seventeenth Ann. Rept. U. S. Geol. Survey, pt. 1,1896, p. 854 .

- Brooks, Alfred H., The geography of Alaska: Prof. Paper U. S. Geol. Survey No. - 
that occur on many of the slopes and often form the tops of the mountains of the Kiwalik-Buckland watershed; third, the lowland plains, the greatest extension of which appears in the vicinity of Ievil Mountain and Kuzitrin River, but which are also well developed in the valleys of all the large rivers. West of the region here deseribed, in the northwest part of the peninsula, Collier has collected evidence for four epochs of erosion, which mark periods of more or less stability during a general movement of uplift, modified by minor movements of depression. The oldest of these is seen in the flattened tops of Ear Mountain, Midnight Mountain, and the mountain mass surrounding the headwaters of Nuluk River and representing the persistent remnants of an ancient plain, now almost completely destroyed, which Collier has called the Nuluk Plateau. This peneplain, if restored, would have an elevation varying from 2,000 to 2,800 feet. Evidence for the second period of erosion is afforded by the Kugruk Plateau, a well-marked plateau surface appearing at a variable interval of from 400 to 1,000 feet below the Nuluk Plateau. It is deeply incised by rounded canyons, and stands at an average elevation of about 1,000 feet above sea level. During the third period the York Plateau was formed at an interval of about 700 feet below the Kugruk Plateau. This is the youngest and most perfect of all the rock-floored plateaus, but is seen only in the western part of the peninsula. The last epoch of erosion is represented by the gravel-covered lowlands that border the sea and the large rivers. Of the four great movements recognized by Collier, two, at least, affected the northeastern part of the peninsula-the movement that gave rise to the Kugruk Plateau and the one that produced the Lowland Plains.

\section{KUGRUK Plateau.}

A glance at the section on the geologic map will give a better idea of this plain than words can. The section extends from a short distance south of Midnight Mountain eastward to Buckland River. From Candle Creek westward the surface of the plain is shown to have an elevation of from 1,000 to 1,400 feet, interrupted at intervals by broad, flat valleys occupied by trunk streams, and at one point by the deep, narrow canyon of the South Fork of Goodhope River. This plain slopes gently to the north, but its regularity is modified, as has already been said, by the valleys of Kuzitrin and Koyuk rivers, which have cut down the southwestern and southeastern parts of the area. That the present streams have carried on their work of reducing this plateau for a very long period of time is plainly shown by the rounded contours of the hills and by the character of the valleys, the main streams having cut the latter nearly to sea level throughout a considerable portion of their length, leaving narrow, $V$-shaped valleys to be seen only on the smaller creeks. 


\section{TERRACES.}

As the traveler approaches the mountain region between Kiwalik and Buckland rivers from the west he is strongly impressed by two features of the topography, (a) the deeply cut valleys and narrow ridges of the central mass, (b) the mesa-like tops of many of the larger mountains and the beautifully eut benches which give the slopes of these the appearance of flights of giant steps leading up to elevated platforms. One of the most noticeable examples of such a flat-topped mountain is found at the head of Kiwalik River in the southeast part of the mapped area. Standing on the broad, level top of the ridge some 12 or 13 miles to the northeast one sees this mountain apparently wholly cut off from the main part of the ridge on the north, thus bringing out its peculiar form all the more strikingly. Its summit, which reaches an elevation of nearly 2,000 feet, is perfectly flat and covers an area of several acres, while its northern slope shows a succession of at least eight benches. Unlike the structure seen in the low mesas to the west, these benches were cut in massive granites and andesites, and only in exceptional cases could they be considered as due to successive flows of igneous rock.

The granite masses southwest of Bear Creek and south of Hunter Creek are fine examples of the same feature (Pl. VIII, $B$ ), as is also the Kiwalik Mountain area. The tops of these mountains are all perfectly flat, and benches varying from 10 to 100 feet in height are found on their sides. Near Hunter Creek the slopes of one ridge show at least 12 benches at different levels. Mr. Witherspoon in his topographic work found that a given bench could often be traced from one locality to another, but the contour interval was too great to permit any extended correlation of levels. The writer was not able to visit personaliy the large flat-topped mountain 12 miles east of Kiwalik, but from its appearance has no doubt that its contour is the result of the same causes which produced the other occurrences just described. The same features are seen on every hand within the area of the main mass, and are too evident to be readily missed by any observer. The floors of the benches are usually covered with débris, which is angular or rounded, and is probably due to weathering rather than to grinding by water currents. The edges of the benches are made up of angular blocks produced by the action of the frost on the bed rock, now only occasionally visible. The blocks appear not to have been moved any considerable distance, but simply to have tumbled down and formed a talus along the front of the rock wall, which they now conceal in nearly all cases.

\section{LOWLANDS.}

Under this head are considered the low, marshy lands which are found hordering the sound and the trrnk streams. As has been 
stated by Collier, they mark the latest period of erosion and deposition, and are made up of unconsolidated gravels and sands laid down in water and afterwards raised slightly above sea level. In general they do not reach a greater elevation than 200 feet, although exceptions are to be noted. The great area of lowland in the Devil Mountain region, previously described, is reproduced in a less degree in the country between Kiwalik and the Buckland and along the east side of Kotzebue Sound; the last named, however, are not included in the map and their description does not belong to this paper. Along the lower Kiwalik the flats have a total width from east to west of 14 or 15 miles and occupy an embayment in the land mass still represented by the shallow lagoon located in its central portion. On the Buckland the lowlands have a maximum width of 8 miles. In the Kuzitrin region the lowlands have a width of over 10 miles, while in Koyuk Valley they extend inland along the river for a distance of 60 miles, with a breadth of 1 to 2 miles in the upper portion, but spreading out for a width of 8 miles on the east side of Norton Bay. These valley lowlands give evidence of long-continued erosion during a time when the land stood at a higher elevation than at present, and in which the trunk streams, after cutting their channels almost to sea level, had carried on for some time the work of widening the valleys, thus producing the broad rock floors on which the gravels were later deposited.

\section{LATER GEOLOGIC HISTORY.}

As recognized by Brooks, ${ }^{a}$ the later geologic history of Alaska may be briefly stated as follows: The lower Cretaceous, marked by an epoch of mountain building, was followed by a gradual depression of the land surface and by deposition, partly in the open ocean, partly in embayments of the ocean, and partly in fresh water, which continued to the close of the Eocene. This depression was probably interrupted by frequent minor movements of elevation and was terminated by an uplift whose time is not definitely known, but it is believed to have begun in late Eocene or early Miocene time. This uplift appears to have been widespread and to have given to Alaska approximately its present contour, at the same time being accompanied by mountain-building forces which produced the great mountain systems already outlined in low relief and now forming two of the four geographic provinces named above. Active denudation was initiated by this uplift and was continued throughout a long period of stability in which the streams finally reduced the land mass to a nearly level surface, now represented by the Yukon Plateau. Another uplift of differential character resulted in the elevation of

\footnotetext{
${ }^{a}$ Brooks, Alfred H., The geography of Alaska : Prof. Paper U. S. Geol. Survey No. -
} 
this platean to something like its present position and the development of the Yukon drainage system as we see it now. Seward Peninsula lies in the extreme western part of this plateau area, but in the absence of information concerning the development of the topography in the intervening territory it scems unsafe, if not impossible, to attempt any correlation between different levels in this region and other portions of Alaska to the eastward where geologic reconnaissance work has been carried on.

With the possible exception of the coal-bearing formations on the Kugruk and the similar formations on the Koynk, which are considered by Mendenhall to be of probable Tertiary age, no Mesozoic rocks are now known to be present on the peninsula. If the apparent absence of such deposits is to be interpreted as indicating the elevation of the land above sea level during that time, then the period through which the weathering agencies were permitted to continue their work of degradation was very great, and one is able to understand somewhat better the possibility of so vast an amount of erosion as must have taken place since the deposition of the known Paleozoic rocks of the peninsula. It should be remembered, however, that more detailed investigation may reveal the presence of Mesozoic rocks now unrecognized, or that such deposits may possibly have been laid down and subsequently removed.

Aside from the question of the time period necessary for its accomplishment, the fact remains that the northern part of Seward Peninsula was reduced to a nearly level plain before the development of the present topography and that this plain itself was later subjected to changes of elevation and to a renewal of the activities of erosive agents which have greatly modified its original character and reduced it to its present state. Even the most recent changes are not wholly clear, for it is difficult to understand how the high rock benches in the eastern mountain area could have been preserved in almost perfect condition throughout a period in which the Kugruk Plateau, 1,000 feet lower down, was being extensively dissected and partly removed. One hesitates, in the absence of confirming evidence, to suggest as a possible explanation a depression of the entire region, amounting to 2,600 feet, since the formation of the broad valleys in the Kugruk Plateau, even though there are indications of the presence of the sea in very recent time at an elevation of 800 feet in the vicinity of Nome, and even though the York Plateau, which is considered to be a relatively young feature in the development of the topography, sometimes reaches an elevation of 700 feet.

The valley lowland and coastal-plain deposits were laid down during a minor period of depression, which retarded for a time, and may have interrupted altogether, the process of stream cutting on the Kugruk Plateau. It is probable that the gravels deposited at this 
time have no very great thickness, and that the eroded edges of the rocks which they cover form floors not differing in their major features from the forms of the gravel plains above them.

This period of depression and deposition was followed in turn by a reelevation, which allowed the creeks and rivers to resume their labor of reducing the land to a common level with the sea. The uplifting movement is believed, from evidence collected in numerous places and by several observers, to be still in progress.

\section{ECONOMIC GEOLOGY.}

\section{LOCATION OF GOLD FIELD.}

The placer gold field whose valuable deposits are now to be described is located in that portion of Seward Peninsula which lies to the south of the eastern extension of Kotzebue Sound. It is about 40 miles long and 20 miles wide, with its longer dimensions parallel to the coast line. This area forms the eastern portion of the Fairhaven mining precinct, the recording office of which is located at Candle, on Kiwalik River. Deering, at the mouth of Inmachuk River, and Kiwalik, at the entrance to Spafarief Bay, are the chief distributing points for provisions and supplies intended for the camps on the upper parts of these streams, as well as for those on Bear Creek, a tributary to Buckland River.

The region offers few attractions other than the gold to the prospector; low moss-covered hills, natural breeding places for mosquitoes and black flies, surround him on every side; traveling, difficult on the higher ground, is almost impossible over the lowlands bordering the sound, and the only fuel for cooking or heating is that afforded by the low willows scattered along the bottoms of the valleys.

The coast line forming the northern boundary of the field is but 30 miles south of the Arctic Circle, and in consequence of its position the region is subject in summer time to much damp weather and in winter to severe cold with strong winds, more trying to the traveler than the lower temperatures but quieter atmosphere of the interior. The area containing all the gold-producing streams lies between the one hundred and sixty-first and one hundred and sixty-third meridians of west longitude, and within 20 miles of the coast, the only exception being Bear Creek, which is at nearly twice that distance.

\section{GEOGRAPHY.}

For the purpose of giving a clearer idea of the placer-gold district, a more detailed description of the geography, especially of that part referring to the drainage, is here given.

The greater part of the region of the gold-bearing gravels presents a topography intermediate in relief between the lava plains of the 
Lake Imuruk vicinity and the rugged country east of Kiwalik River. Numerous small streams cutting their way into a much-dissected plain have produced a succession of broad, rounded hills, averaging from 600 to 800 feet above sea level, the monotonous appearance of which is broken to the south and to the east by higher points, reaching in some instances an elevation of from 1,500 to 2,000 feet or more. Three of the five principal streams that empty into the southern part of Kotzebue Sound cross the gold field. On the west, Inmachuk River, with its northern tributary, Hannum Creek, heads against Trail Creek and the headwaters of Goodhope River. It follows a meandering northeasterly course, first through a lava-rimmed valley and then across the coastal plain, till it reaches the sound at Deering. Its largest branch, Pinnell River, rises a few miles northeast of Lake Imuruk, in the small ponds of the level lava-covered area north of the Bendeleben Mountains, and joins the Inmachuk at the new mining camp, Recorl. Its larger tributaries on the west, Old Glory, Perry, June, and Magnet creeks, drain the area east and north of the Asses Ears.

Kugruk River, also called Swan River, which crosses the central part of the gold field, rises in Lake Imuruk, follows a northeasterly direction for about 15 miles, and then flows north to within 9 or 10 miles of the coast, where it bends sharply westward and continues to the west for 6 miles to the "bluffs," where its former northerly course is resumed and held to the sound. The valley of the Kugruk, especially in the lower part, is a broad, flat plain, a mile or two in width. Lagoons and old abandoned channels, filled with water, but no longer connected with the main channel except in time of freshet, are frequent, so that traveling is often slow and difficult. The Kugruk is larger than the Inmachuk or the Kiwalik and at the same time much more crooked. It has a number of tributaries of considerable size, but no one of them up to the present time is of much importance as a gold producer. The largest of these tributaries is Wade Creek, which comes in on the west side and joins the river near the center of the big bend. Chicago, Reindeer, Montana, Mina, and Independence creeks are the larger streams coming in on the east. All have been staked, but little prospected.

Kiwalik River, still farther east, is the third river crossing the gold field. It empties into Spafarief Bay and drains the western slopes of the eruptive mass southeast of Candle, as well as the high hills to the south. Of the numerous tributaries of the Kiwalik, Candle Creek is by far the most important from an economic standpoint. It flows in from the southwest and joins the main river at Candle, about 9 miles from the coast. The other large tributaries on the west are Stanley, Glacier, Dome, and Gold Rum creeks; on the east, Hunter and Quartz creeks. 


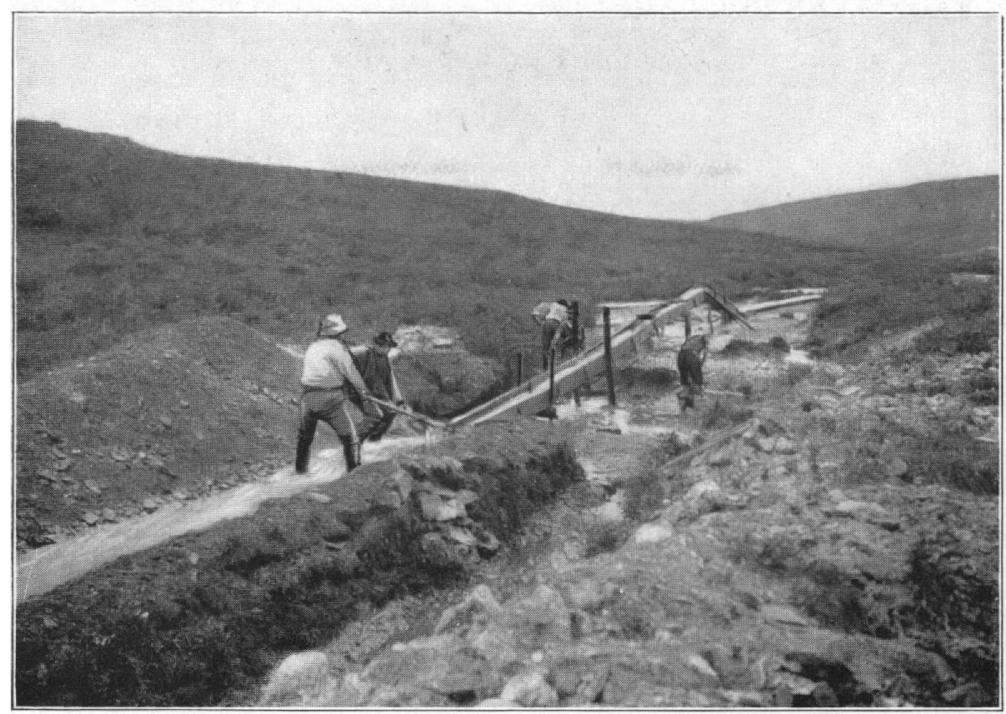

A. SLUICING ON HANNUM CREEK.

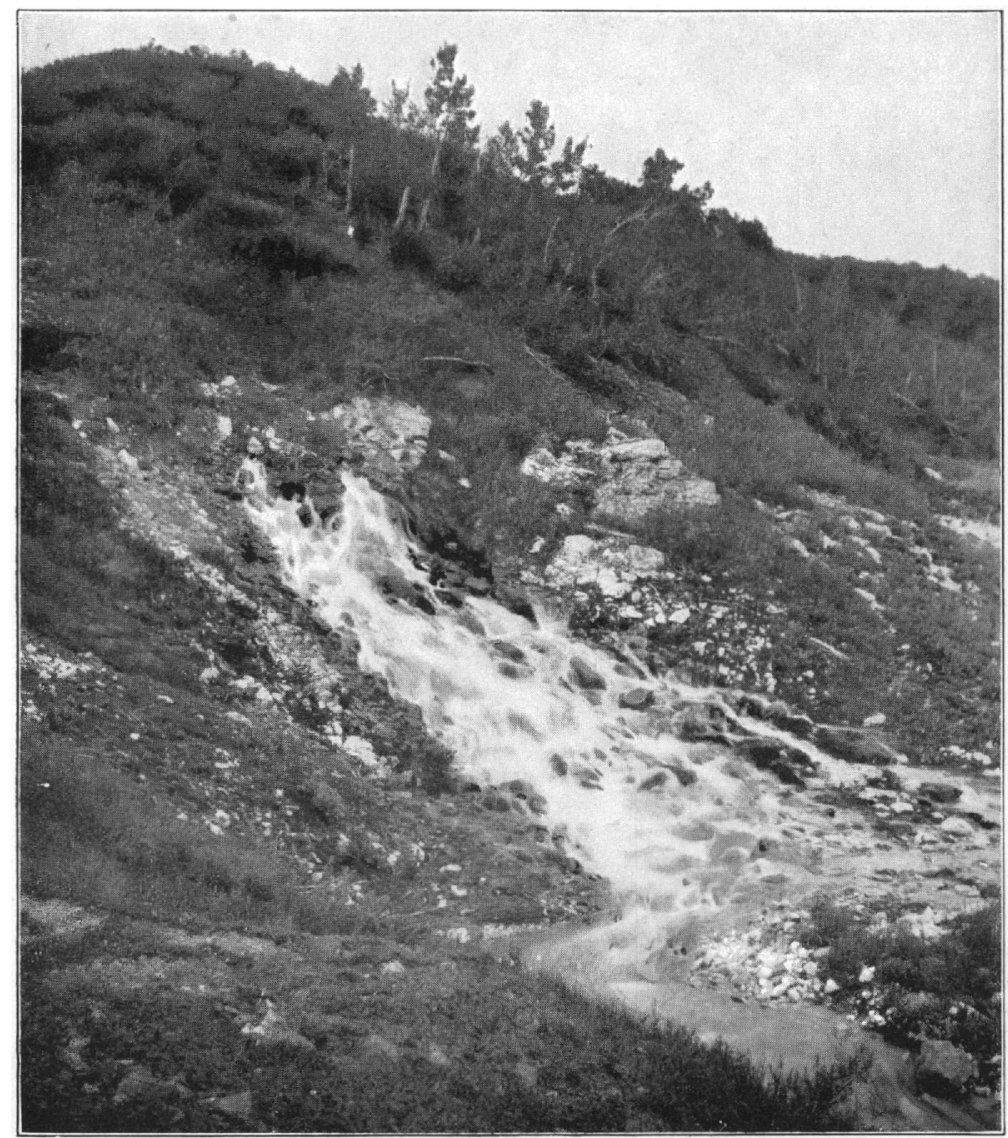

B. "HOT SPRINGS" ON UPPER INMACHUK RIVER. 

The most easterly, as well as the largest, of the rivers emptying into Kotzebue Sound from the south is the Buckland. It lies, perhaps, somewhat outside of the gold field propér, but is included in the same recording district and should be mentioned, since one of its tributaries, Bear Creek, has been a small producer during the season of 1903.

All of these streams have gentle gradients in their lower stretches, and meander widely over the lowlands near the coast, producing bars and mud flats which often embarrass even the lightest of the small boats used in freighting supplies to the mining camps.

\section{HISTORY.}

The first prospecting in the Kotzebue gold field was done in the latter part of the season of 1900 by William T. Fee ("Missouri Bill"), who discovered gold on Old Glory Creek in the fall of that year. Mr. Fee seems to have prospected all the streams heading up toward the east side of the Asses Ears, but did no staking, owing to the failure of his supplies and the consequent necessity of returning to Nome as quickly as possible. Old Glory was staked on September 21 of the same year by William H. Davis and Jessie Pinnell. Three days later, on September 24, gold was discovered on Hannum Creek, a tributary of Inmachuk River, by Z. E. Foster and Fred Sandstrum, who staked the creek on that day.

No work was done on the gravels in the fall of 1900 , owing to the shortness of provisions and the lateness of the season. Snow was already falling, and the prospectors returned to Nome, the nearest recording place to this then unknown region, to register their claims and prepare for active work during the following season. Their reports on the region caused considerable excitement among the miners wintering in Nome, and some time in the early months of $1901 \mathrm{M}$. V. Perry crossed the country on the snow with a dog team and staked the creek now known by his name, Perry Creek.

With the opening of spring a considerable rush of prospectors to the new field took place, and a large number of claims were staked on nearly all the neighboring creeks, both to the west and to the east. The first locations on the Inmachuk proper were made by Messrs. Applegate and Perry on Discovery, at "Hot Springs" (Pl. IX, B), $2 \frac{1}{2}$ miles above the mouth of the Hannum. Very little work aside from the location of claims was done in the Inmachuk Valley during 1901 , for in the latter part of the season the news of very rich finds on Candle Creek drew many men away and notably retarded the development of the properties. This condition continued during the season of 1902 , but the summer of 1903 witnessed a revival of interest in the Inmachuk and its tributaries, and a still further increase in the development in 1904 is certain.

Bull. 247-05 M- -4 
Candle Creek was staked about July 23, 1901, by Messrs. Enos Thomas, Alexander Patterson, Robert Schneider, and Blankenship, and up to the present time has produced a much greater amount of gold than any of the other streams of this field. Although $\mathrm{Mr}$. Blankenship was probably the first miner to drive stakes on Candle Creek, Messrs. Thomas, Patterson, and Schneider were the first to enter the region and made the original discovery of gold on Jump Creek, a small tributary which comes in from the west and joins Candle Creek about $1 \frac{1}{2}$ miles above Kiwalik River. These four men staked claims on the most promising portions of the main stream and one claim each on the lower ends of the tributaries, thus acquiring right to a considerable amount of ground, part of which has proved to be of much value.

News of the strike spread quickly and was followed by a stampede of miners in the late fall, so that the entire creek was soon taken up and scores of men with rockers busied themselves in cleaning out the richer and more readily worked portions of the gravels. As high as an ounce of gold per day was paid to shovelers on some claims.

During the summer of 1902 mining was carried on vigorously on nearly all the claims between Potato Creek and Kiwalik River, with the result that a large part of the channel has been worked over in a hasty manner, and most of the easily obtained gold has been talken out. As a natural consequence of this fact, the season of 1903 showed a very large decrease in the number of men on the creek, not over 125 being actually engaged in mining operations at any one time. Mary of those who took part in the stampede of 1901 and 1902 have since gone back to the earlier-found diggings of the Inmachuk region, while not a few have turned their attention to the bench claims of Candle in the belief that these may contain gold deposits as valuable as those found on the creek.

Candle Creek is said to have received its name from the fact that in the springtime, when the prospectors first saw the stream, the willow twigs along its banks were covered with a thick coating of ice, and suggested the name because of their resemblance to candles.

Bear Creek, which is situated about 40 miles southeast of Candle, was first staked and recorded in August, 1901, by R. L. Howie, Louis 'Tendness, and Andrew Barr, but the natives say that the stream had been staked the previous year by Thomas, Patterson, and Sneider, the discoverers of gold on Jump Creek. If such was the case, no record of the locations was filed. Mining operations on this stream have been prosecuted under great disadvantages, owing to the difficulty of obtaining supplies and the high cost of freighting. Buckland River, because of its frequent sand bars and crooked channels, is not a practicable route, and freight charges over the 40 miles of tundra from Candle to Bear Creek have never been less than 20 cents per pound. 
The total production of the Kotzebue gold field for the three years during which mining operations have been carried on is probably not far from $\$ 415,000$. Of this amount Candle Creek alone has turned out over three-fourths.

\section{DESCRIPTION OF THE CREEKS.}

The gold field immediately south of Kotzebue Sound is divided naturally into three minor fields, defined by the watersheds separating the drainage basins of Inmachuk, Kugruk, and Kiwalik rivers. The streams in the Inmachuk River Valley, including the south fork, or Pinnell River, which up to the present time have been gold producers, are few in number and as yet only partly developed. Old Glory and Hannum creeks, with two or three small tributaries, are the chief ones besides the Inmachuk and the lower part of Pinnell River that merit special attention at this writing. Even from these, although several claims have been worked steadily from the opening of the region, the output is not large, since the gravels have not been worked systematically and many properties were entirely deserted by their owners at the time of the greatest excitement at Candle.

The members of the Kugruk drainage system give evidence, by occasional ditches and heaps of washed gravel, of some work in the past, but while one or two of them have produced a very small amount of gold, they have not yet shown the presence of gravel deposits of sufficient value to warrant the expenditure of much time or money in their development. In the southern part of the valley, however, gravels were being prospected during the last summer (1903) with some success. These gravels are on Dixie Creek, which flows into Independence Creek, the large eastern branch of the Kugruk.

A great number of claims have been staked and recorded on the various streams composing the drainage system of Kiwalik River, and the same is true in a less degree of part of the Buckland tributaries. Very few of these claims, however, with the exception of those on Candle and Bear creeks, have received any further attention whatever, although it was almost entirely through reports from this part of the region that the Kotzebue gold fields became known to the outside world.

An attempt has been made to show on the geologic map the distribution of the gravels which are producing or have produced gold in commercial quantities and also of those which are known to carry gold, but not in sufficient amount to be of value under present conditions. It should further be said that colors, and perhaps even larger quantities of gold, have been found on many of the streams besides 
those indicated, the metal being widely distributed throughout the crystalline schists.

In the following more detailed account of the gold-bearing gravels the streams are described from west to east, the order in which they were visited by the writer, and although an effort was marle to obtain full information concerning development during the latter part of the season, from miners coming into Nome for the winter or on the way to the States, it is possible that some of the facts brought out: by the summer's work were not secured. The writer wishes to express his indebtedness to the many prospectors, too numerous to mention' individually, from whom he has received valuable information and aid or whose generous hospitality he has enjoyed.

\section{INMACHUK BASIN.}

Hannum Creek.-IIannum Creek joins Inmachuk River $2 \frac{1}{2}$ miles west of Record. The stream, which is about 9 miles long, occupies a deep canyon-like valley, which in a few places expands for stretches of half a mile or less into a level floor 600 to 800 feet in width. These level places are usually wet and difficult to traverse because of the moss. The valley is cut into a series of schists and shales interstratified with occasional thin limestone beds, and is surrounded by a capping of lava of no great thickness. The schists and slates of the valley slopes are generally covered by the débris from the overlying lava, so that outcrops are not plentiful and the structure is difficult to determine. Where exposed the schists are generally veined with quartz.

The lava itself is rarely found in place, but its presence is shown where the watercourses have cut through the flow, by heaps of angular blocks and rounded gravelly deposits which mark the location of former outcrops and cover its contact with the underlying schists and limestones.

The gravels covering the valley floor are made up principally of schist and pebbles of quartz-vein stuff, together with smaller amounts of limestone and lava. Scattered lava bowlders of considerable size, found at various places along the channel of the stream, are at times troublesome to the shovelers. In the few places where bed rock was exposed the gravels showed a thickness of from 2 to 6 feet, and all, with the exception of those in the channel, were covered by 12 to 18 inches of moss. No ice beds, or "glaciers," as the miners call them, were exposed at the time of the writer's visit, and no gravels which required thawing were being worked, since, as yet, little attention had been given to deposits other than those of the stream channel.

The gold is unevenly distributed over the bed rock, and on only one claim had anything like a continuous pay streak been exposed. Here the valuable gravel deposits had a thickness of from 6 inches 
to 4 feet and a width approaching 100 feet. Its extension to the adjoining properties above and below had not been demonstrated.

Besides the gold, the heavy concentrates from the sluice boxes show a large number of rounded and polished pebbles of hematite or "iron stones," some pyrite, and a small quantity of galena, which is probably derived from the limestone area west of Cunningham Creek, and will be referred to again. Black sand is not found with the gold, since magnetite occurs in very small quantity; the magnet discovers only occasionally small pieces in the tailings from the sluice boxes. "Gray sand" or finely ground pyrite appears constantly in the pan, and larger pieces up to 2 or more inches in diameter are not infrequent. The best gold values are taken from the bed rock, which is usually a blue clay resulting from the decomposition of the underlying schists. The gold is heavy and black and is said to assay about $\$ 18$ to the ounce when cleaned. Nuggets worth $\$ 2.50$ are not uncommon, but no very large ones have yet been found.

Not more than 8 or 9 of the 45 claims which have been staked on Hannum Creek, and extend from the month of the stream at No. 20 below Discovery to the source at No. 25 above Discovery, were being worked at any time during the season of 1903. No development work of consequence ( $\mathrm{Pl}$. IX, A) has been undertaken below I)iscovery at the mouth of Collins Creek nor above the mouth of Cunningham Creek. Between these points the gold is coarser, and the grade of the stream sufficient to pernit the use of bed-rock drains, so that pnmps are not required. Toward the mouth of Hannum Creek the grade decreases noticeably and the gold becomes finer and brighter in character. It appears to have traveled some distance and is more difficult to save than the heavier gold above. Although there is said to be sufficient water at all times of the year for sluicing purposes, the work so far done can hardly be considered sufficient to determine the future of the creek. During the season of 1903 a large part of the supplies for these workings was landed on the beach at the mouth of Rex Creek and brought south over the divide by pack horse or wagon, a method which has proved more satisfactory than that of carrying the freight to the mouth of the Hannum in small boats, since the use of horses is still necessary from that point onward and, furthermore, the shallows of the Inmachuk offer difficulties to the lightest boats.

Cunningham Creek.-The largest tributary to Hannum Creek is Cunningham Creek, a short creek, a little more than 2 miles long, which joins the larger stream about 7 miles from its mouth. Like Hannum Creek it flows over a schist bed rock. The valley is narrow and V-shaped and its sides are capped through much of their length by the shattered outcrops of the lava flow so widely developed in this region. The gravels are schist and vein quartz, with a small percent- 
age of limestone at the lower end. The Cunningham gold is coarser than that of Hannum Creek, but has never been found in large amount. One thousand two hundred dollars is said to have been washed out just above the mouth of the stream in 1901.

Three-fourths of a mile above the mouth of Cunningham Creek a small tributary called Harry Creek comes in from a limestone area on the west, where a prospect hole was sunk to bed rock at a little distance from the stream and disclosed a vein of galena in limestone. Little schist appears in the stream deposits, which consist chiefly of limestone, and it seems probable that the galena found in the sluice boxes on Hannum Creek may come from this source.

Collins Creek.-Collins Creek joins Hannum Creek at Discovery, but has not yet been much prospected, although the discoverers of Hannum Creek found their first colors on it and coarse gold is known to occur there.

Old Glory Creek.-The presence of valuable gold fields south of Kotzebue Sound was first demonstrated, as has been previously stated, on the creek now known as Old Glory. This stream takes its rise in the limestone area northwest of the Asses Ears, follows an eastnortheast direction for a distance of nearly 6 miles, and reaches Pinnell River $1 \frac{1}{4}$ miles south of the new mining camp of Record. The lower 4 miles of this course is directly across the bedding and cleavage of the schists, which occur to the east of the limestone area just mentioned. No contact of the limestone and schist was seen, but the boundary separating the two formations lies between one-half and three-fourths of a mile to the west of Nelson Gulch. These schists are at times slightly graphitic and are interstratified with occasional limestone beds. Lava rims are present along the lower portions of the valley, but are not so conspicuous as they are on the streams previously mentioned.

Quartz lenses and stringers appear in all the schist outcrops, and angular blocks of vein quartz strewn along the hilltops have now and then furnished locations for quartz-ledge claims. The cleavage dips quite constantly toward the northeast, so that the waters, in carving out the valley, impinged against the upturned edges of the inclined schist slabs, which acted like the riffles in a sluice box in concentrating the gold. This relation of stream course to cleavage may account also for the presence of the broad, rounded basins, or " pot holes," as they are called by the miners, which occur in the bed rock of the channel and are a source of some difficulty in the operation of mining. It should be said that the term " pot hole" is not used in this connection by the men on Old Glory with its usual significance-implying a rounded hole with considerable depth relative to the diameter-but is understood to mean a depression in the bed rock with diameter very much greater than depth. The average cross section of the valley is a 
broad $V$, becoming narrower and canyon-like in the limestone hills of its upper end, but widening out as it approaches Pinnell River.

A vertical section of the gravels was difficult to obtain, since the few holes which had been put down to bed rock were made during the winter time and caved in when the spring thaws came. Bordering the channel of the stream and extending for a short distance on either side there is usually a bed of ice, reaching at various points a thickness of 4 feet, which overlies the gravel and is covered with moss. By the thawing of the ice edge nearer the channel and the consequent falling in of the overlying turf, and by the slipping of larger masses of débris from the sides of the valley down over the ice, a mixture of rock, gravel, and vegetable matter has been produced, which the miners call "slide." In the only place where work has been done-that is, in the channel of the stream-the gravels are composed of fine schist with quartz and limestone, the schist being more conspicuous than either of the other two constituents. The character of the gravels is modified in the lower course of the stream by the presence of pebbles and bowlders of lava from the hilltops. Washed gravels are found well up on the slopes of the valley and differ markedly from the stream deposits, owing to the larger percentage of quartz pebbles which they contain.

Fairly well-defined gravel benches are seen in the valley near Nelson Gulch and a short distance below, but their presence is not so easily determined lower down, where, if ever developed, the ice and stream have both helped to remove them.

In a few instances the former channel evidently had a position somewhat different from that occupied by the stream at present. One interesting piece of evidence tending to establish this fact is an old beaver dam a short distance north of the present stream bed, which was uncovered by prospectors while making a crosscut to determine the location of the former channel. This dam was deeply buried under a mass of débris, the cut showing a thickness of nearly 10 feet of slide, muck, and partly decayed vegetable matter, overlying fine sandy gravels.

Both pyrite and hematite, "iron stones," are found in the sluice boxes. The pyrite frequently retains its crystalline form, while the hematite is worn smooth and well rounded by the action of the water. Some of these hematite pebbles are probably derived from the alteration of pyrite, for the pieces, when broken, occasionally show fine yellow particles of that mineral. As assays showing tin are reported, a careful examination of tailings from the sluice boxes was made at two or three places where work was being carried on, to establish, if possible, the truth of this report. None was found, but later information was received from Dr. Cabell Whitehead, of the Alaska Banking and Safe Deposit Company, that some 27 ounces 
of metallic tin were obtained from gold brought to the bank from Old Glory Creek, the metal occurring in the form of fine cassiterite grains, which, because of their weight, remained in the pan with the gold.

The gold from Old Glory is heavy and black; it occurs irregularly on bed rock along the channel, but at no place on the stream can a well-defined pay streak be shown. The smaller " pot holes" are said to be quite rich and to carry the best values on the rim, the larger basins returning a smaller profit to the miners. These pot holes are more difficult to work than are the other gravels, since it is necessary to shut out the water from the main channel and to keep the holes pumped out, and such work is not required where a bed-rock drain can be used, as is generally the case. Drains and ditches for sluicing purposes are occasionally made by simply removing the moss and allowing the water to melt its own channel through the ice bed beneath. Ditches constructed in this manner may, however, be hard to control and require close watching to avoid their breaking out and causing the loss of valuable time or doing other damage to the workings. There is plenty of water for the requirements of the sluice boxes at all times with the exception of a week or two at the end of a season during which there has been less than the usual amount of rain. A water right of 500 miner's inches for hydraulic-mining purposes has been staked at the mouth of the creek with the intention of carrying the water down to the claims on the Inmachuk.

Practically no development work was done on the stream during the summer of 1901, but at the opening of the following season ground was prepared for sluicing at a number of places, and nearly the whole of the channel on two claims was washed out. Little gold has been found on Old Glory above Nelson Gulch, as might naturally be expected from the nearness of the limestone boundary to the west, since no evidence has yet been found in this part of the region to show that gold occurs originally in the massive limestones. The total production of the stream is not great, probably not over $\$ 30,000$, of which much the larger part was taken from a single locality just below Nelson Gulch.

Nelson Gulch.-This small gulch (Pl. X, A) barely three-quarters of a mile long, leads down from a broad, low saddle in the divide between Old Glory and the Inmachuk, and is of interest since it is probably an important factor in the origin of the rich ground just below its mouth on Old Glory. Schist crops out occasionally along the banks of the shallow depression, through which, in the springtime, a small stream flows, and on either side of the lower end of the gulch the well-developed gravel terraces have been staked as bench claims, but have not yet been prospected to determine their value. 


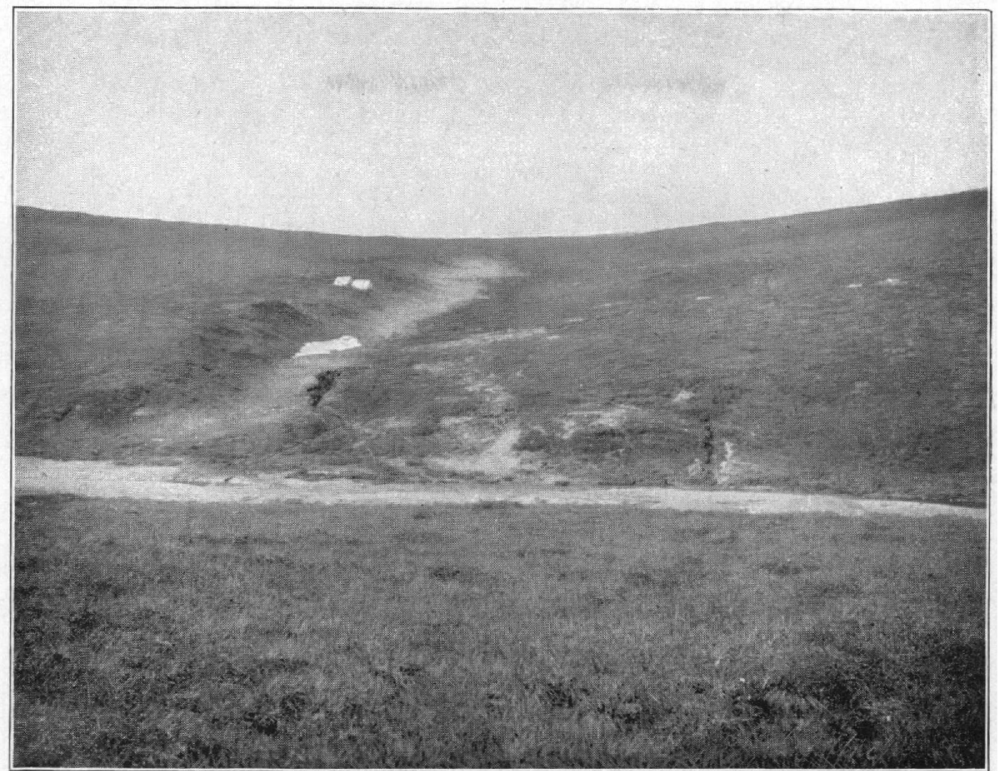

A. NELSON GULCH.

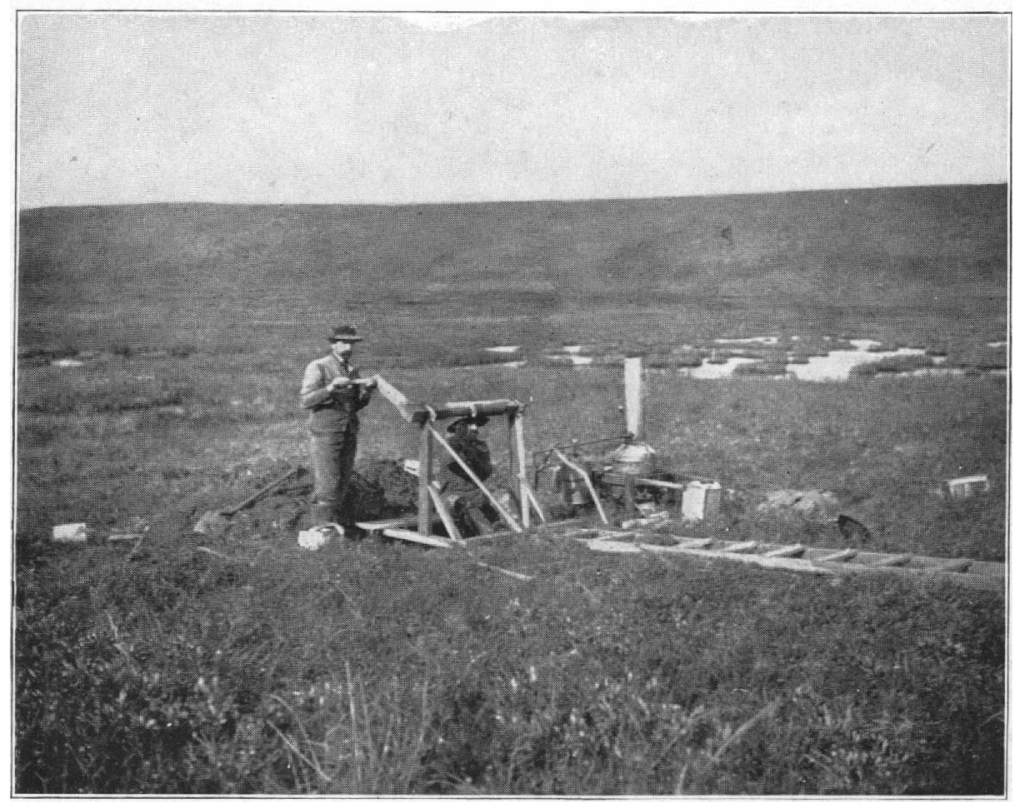

B. AUTOMOBILE BOILER USED FOR THAWING FROZEN GRAVELS ON INMACHUK RIVER. 

A cut through the gravels on the east side of the gulch and 300 to 400 feet from its mouth afforded the following section:

Section at Nelson Gulch, Inmachuk basin, Alaska.

Muck
Blue clay
Red clay
Vegetable muck, with willow twigs, irregular in
thickness -10 inches.
Decomposed schist in places.
Greenish gravels
Schist bed rock.

The uncompleted cut just referred to seemed to indicate plainly the presence of a former channel at some distance to the east of the present watercourse.

Not much sluicing has been done on Nelson Gulch since the early part of the season (1903), owing to the scarcity of water. It was expected, however, that this difficulty would be removed by the completion of a ditch more than a mile long which was being dug to loring water from a higher level on Old Glory.

The gold is brighter than that of Old Glory, is rough and angular, and contains considerable quartz, and evidently has not traveled far from its original source. With the magnet a few grains of black sand may be found associated with a much larger amount of pyrite and some ruby sand. Not much gold has been taken out, but the valuable gravels found just below the mouth of the gulch add interest to the possible results of future development.

American Creek.-American Creek is the largest tributary of Old Glory, and heads up toward the north side of the Asses Ears. The gold is brighter than the other gold of the vicinity, but has never been found in quantity to encourage the prospector much, and in consequence there was little or no work on the creek last season (1903). Since there is good authority for the occurrence of tin ore in the gravels of Old Glory, it is suggested that American Creek and those tributaries of Pinnell River which approach the granite areas of the Asses Ears neighborhood may be favorable localities in which to prospect for that ore.

Pinnell River.-The eastern branch of the Inmachuk, known as Pinnell River, is about 12 miles long and, with its tributaries-Perry, June, and Magnet creeks-drains the area east of the Asses Ears. Prospecting on the upper part of Pinnell and also on June and Magnet creeks has been attended with difficulties arising from the presence of quantities of lava blocks in the stream bed. The only ground on Pinnell River which, at the time of this writing, has been productive of any values lies below the mouth of Old Glory; the amount taken out is small. 
A water right for 1,500 inches was staked on the Pinnell at the mouth of Old Glory, and, with the 500 inches to be taken from Old Glory, would make a total of 2,000 inches, which it was expected would be available for sluicing on the Inmachuk.

Perry Creek.-Perry Creek is 6 miles long and joins the Pinnell 3 miles above the mouth of Old Glory. Some fine, bright gold has been found on it, nuggets worth 10 and 15 cents being found in gravels a veraging about 2 cents to the pan. Perry Creek, like Old Glory, has wash gravel composed chiefly of quartz pebbles well up on the sides of the narrow valley, at an elevation of 400 or 500 feet, but no section to bed rock has been exposed. The scarcity of water in the creek at some seasons of the year and the difficulty of securing any other supply would be a great disadvantage in the working of these high gravels if they should ever be shown to carry important values in gold.

Inmachuk River.-The probability that valuable gold-bearing gravels might be present on Inmachuk River did not begin to be appreciated till the winter of $1902-3$ and the following summer. Work was confined chiefly to the smaller streams, since the broad, flat valley of the main river appears to have been less attractive to miners than the more easily worked gravels of the tributaries, where fewer men and a smaller outfit could be employed. Development operations so far have, therefore, been largely in the nature of prospecting.

The river rises in the limestone country of the divide separating the Inmachuk drainage from that of the Goodhope, follows a northeasterly course for about 12 miles, through a valley of varying width, till it reaches the flats bordering Kotzebue Sound, and from that point onward meanders widely over the lowlands in the same general direction, thus greatly increasing the distance to be traversed before reaching the sea.

The upper valley is narrow and steep as far down as the mouth of Hannum Creek, where a series of gravel flats begins, which continues throughout the lower part of the river. Where well developed these flats have a width of from 400 to 500 feet, increasing below the mouth of the Pinnell to more than a quarter of a mile in places.

Schist, with interbedded limestones of no great thickness, forms the bed rock and is capped along the whole valley with the ever-present lava flow, which, near Record, has a thickness of less than 50 feet and lies about 300 feet above the stream. This black, level line of broken lava blocks is to a geologist the most conspicuous feature of the topography of the region. The sides and bottom of the valley offer a poor road for foot travelers and a still worse one for horses; consequently boats are generally employed in the summer time for transporting supplies from the coast to the camps. 


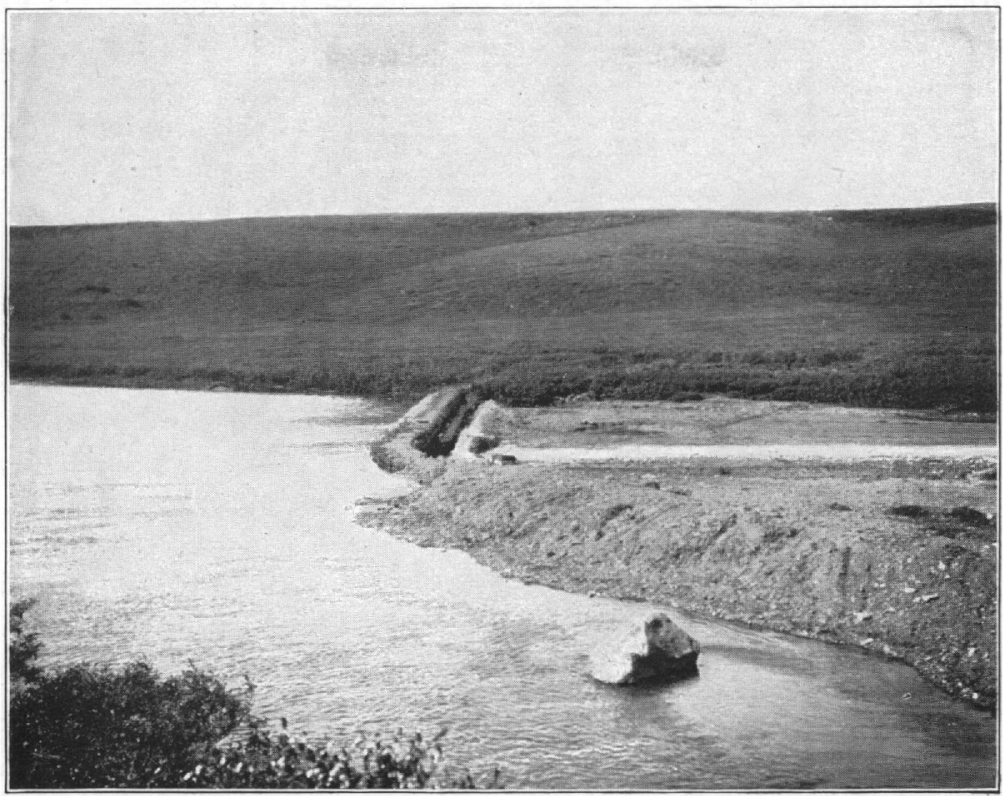

A. DAM ON THE LOWER INMACHUK FOR DIVERTING THE STREAM FROM ITS BED.

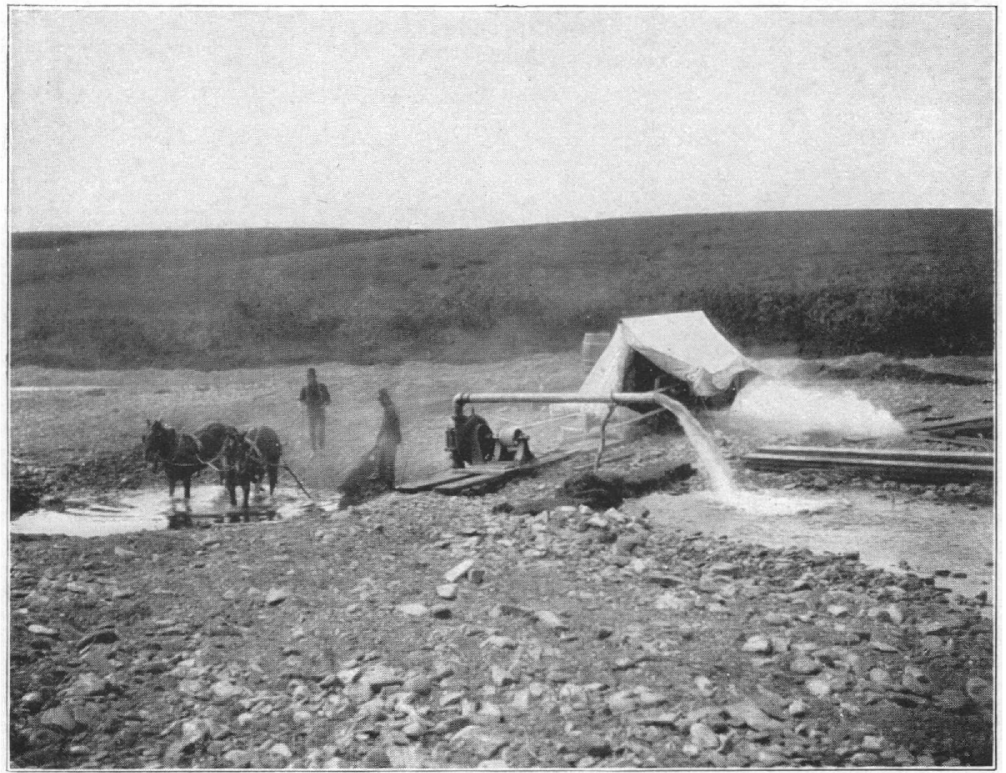

I. PUMP ON THE LOWER INMACHUK. 

The Inmachuk gravels are of the same character as those already described on Hannum and Old Glory creeks; schist forms the greater percentage and is associated with pebbles of quartz, lava, and limestone. Sand naturally is more noticeable than on the steeper grades of the smaller creeks. Beneath the moss the gravel is invariably frozen and often overlain by an ice bed, necessitating the use of some method of thawing before any excavation can be made.

The following section was measured a short distance below Pinnell River:

Section on Inmachuk River below Pinnell River, Alaska.

Feet.

Fine gravel and sand ("chicken feed")

Wash gravel with quartz

Light sand and gravel, mostly quartz

Pay streak of few inches on bed rock of hard clay.

Three miles below another section was obtained:

Section on Inmachuk River 3 miles below Pinnell River, Alaska.

Feet.

Muck -.-

Sandy clay _._._._-_-_._. 3

Gravel, consistency of schist, quartz, and limestone_-_-_-_- 6

Schist bed rock.

A section of somewhat different character was measured near Washington Creek :

Section on Inmachuk River near Washington Creek, Alaska.

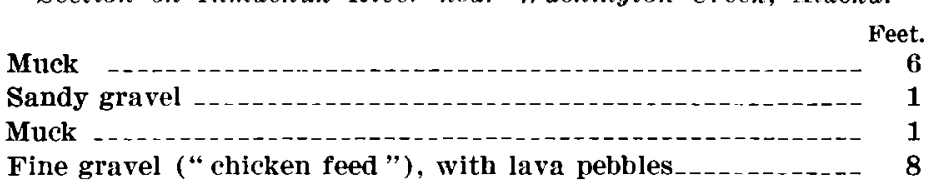

Schist bed rock.

In general, it may be said that on the benches the moss and muck averages from 2 to 7 feet and overlies gravels of variable thickness, which is in places as much as 8 feet. The character of the "bed rock" changes, as the underlying schist or limestone is covered with clay or is bare. Systematic search on the part of some, and development work on the part of others, have shown the presence in a number of places of a well-developed pay streak. One pan of $\$ 20.30$ was taken from a hole thawed down to bed rock early in the last season, and up to that time was the largest single pan known on the creek. The bottom of the hole yielded $\$ 161$. The news of this rich find stimulated the search for gold to a marked degree, especially on the bench claims, and has added much to a knowledge of the gravel deposits. Pans of $\$ 7, \$ 9.95, \$ 11.90$, and a six-pan bucket of $\$ 34$ were washed out near the mouth of the Pinnell. Below the Pinnell, 
near Washington Creek, a 5-foot bed of gravel averaging 15 cents to the pan, and still farther down a gravel bed yielding from 10 cents at the top to $\$ 1.10$ on bed rock, have been slightly worked.

The gold is heavy and black; it appears to be very little worn, and nuggets having a value of several dollars are not uncommon. $\Lambda \mathrm{t}$ times it contains some quartz, and occasionally is seen in the form of fine veinlets in broken pieces of hematite. Associated with the gold is a large quantity of rounded hematite pebbles or " iron stones" and some pyrite, which is finer than the hematite and only partly removable in the sluice boxes. In cases where the bed rock is limestone it is usually necessary to throw into the boxes at least a foot of the top rock in order to make sure that all the values are obtained.

Thawers have been used more extensively on the Inmachuk than on any of the other streams of the field, with the result that in two places the flats of the valley have been crossed by a series of holes from 15 to 30 feet apart and from 14 to 20 feet deep. In a number of places series of holes extending part way across the valley have been sunk. Thawer's of various patterns are employed for the purpose, the most novel one being a small boiler from an automobile (Pl. $\mathrm{X}, B)$, which could be readily carried by two men, and proved very successful for prospecting purposes, because of the ease with which it could be moved and its quick steaming character. This boiler furnished steam for two 4-foot points, making two settings each day, and used oil is fuel. Owing to the large quantity of water in the rivers, dams (Pl. XI, $A$, ) and ditches of considerable size and strength are required for diverting the stream when the channel gravels are sluiced, and are difficult to keep in order because of the seepage through the underlying sands and gravels, for none of the dams are put down to bed rock. Pumps (Pl. XI, B) are also necessary to keep the workings cleared of water. The use of the horse scraper (Pl. XII, $A$ ) in stripping and in removing tailings from the sluice boxes has proved economical in the large workings, and will probably be more widely extended in the future. There is an abundant supply of water in the river for all requirements under present methods of mining, but the claim for 2,000 inches from Pinnell River and Old Glory at the mouth of the latter stream probably exaggerates the quantity that can be obtained at that point during some seasons. If hydraulic methods are introdnced, the use of elevators would be required for the treatment of gravels on the lower Inmachuk.

KIWALIK BASIN.

Candle Creek.-This best known of all the gold-producing streams of the Kotzebue field has given rise to the largest mining camp in the northern part of Seward Peninsula, and has yielded more than three times as much as the combined output of all the other creeks. 


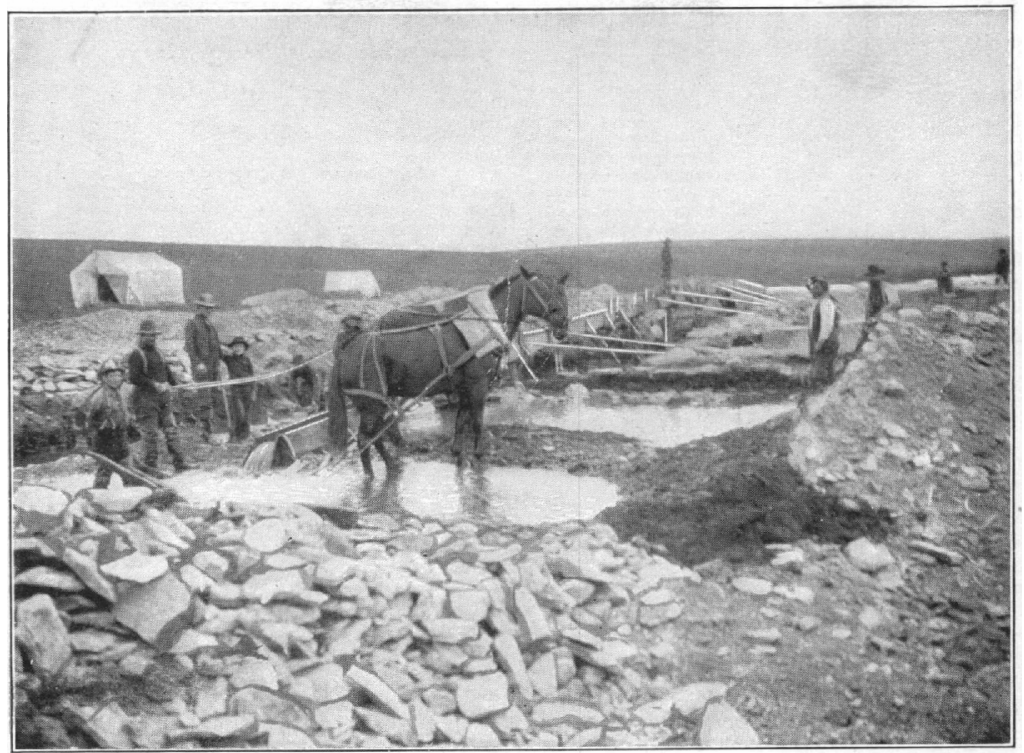

A. SLUICING ON INMACHUK RIVER.

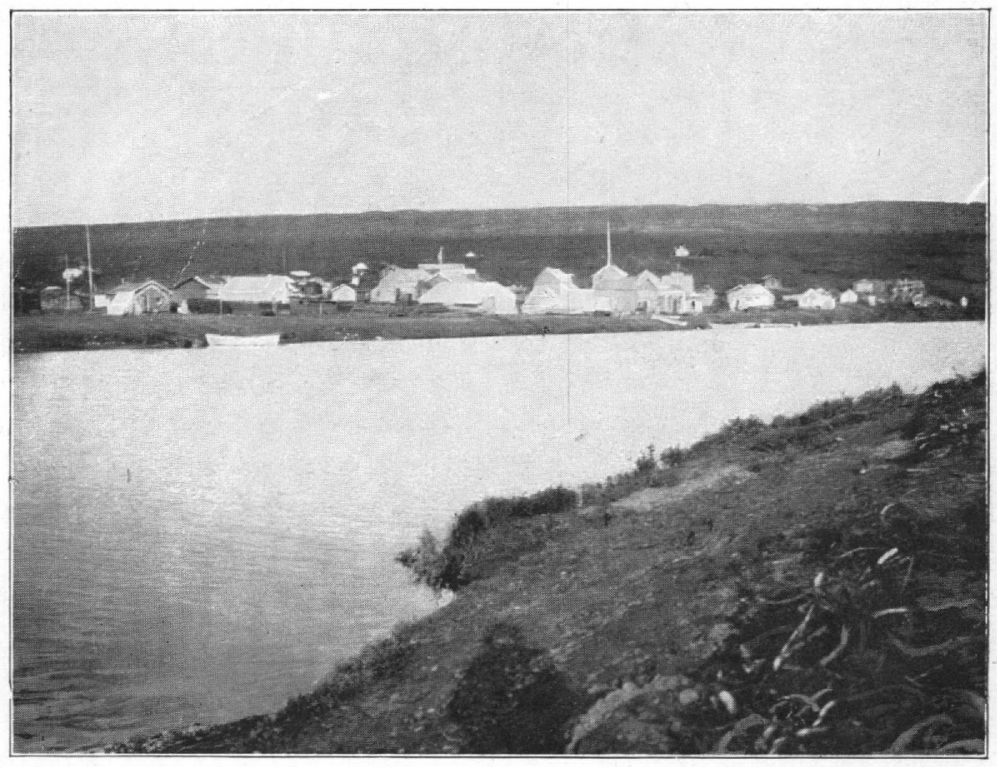

3. CANDLE, ON KIWALIK RIVER AT MOUTH OF CANDLE CREEK. 

From headwaters to mouth, a distance of 16 miles, every foot of the ground has been staked, though not prospected, and some 66 claims have been recorded at Candle (PI. XII, $B$ ), the recording office for the Fairhaven mining precinct. The low, rounded, barren hills and wet lowlands adjacent to Kiwalik River and its tributaries on the west would seem to the ordinary traveler a most unpromising place in which to expect rich gold deposits, and there are certainly no other inducements offered by the region to the prospector. Candle Creek heads in the main divide between the north and south drainages of the peninsula. It follows a course nearly north-northeast and joins Kiwalik River at Candle, 6 miles above the head of Spafarief Bay and 9 miles south of the sand pit on which the town of Kiwalik is situated. The stream occupies a broad, shallow valley with sides sloping so gently that water does not drain off as readily as in the other valleys of the field, and in consequence traveling is more difficult. The lava rim is not so conspicuous here as on Inmachuk and Kugruk rivers, but its presence is made known by fragments in the gravel and on the hill slopes and by occasional outcrops. Exposures of the schist are rare, except where uncovered by the miners. Thin limestone beds are not unusual in the schists, and a small area of lightcolored gneissoid rock is found on Potato Creek. Schist (often coarse and angular, at times finely divided) forms much the larger part of the gravels in the channel. Quartz-vein stuff with some limestone makes up the remainder. An ice bed of variable thickness, which measures about 12 feet near Patterson Creek and extends to the west of the stream channel several hundred feet, overlies the gravels in the bottom of the valley. The tendency of the débris on the slopes of either side of the valley to slide down toward the creek is shown by the bulging up of the clay from the bottom of the cuts and by the closing in of the sides. In consequence of this tendency the gravels are usually much disturbed and there is no uniformity in the sections. At the mouth of Patterson Creek there are from 6 to 8 feet of gravel and slide resting on a blue-clay bed rock; at Willow Creek the gravels measure from 5 to 8 feet; on a bench claim below Patterson Creek the gravels are not so thick- 4 or 5 feet of fine schist, "chicken feed," is covered by 10 or 12 feet of ice and 2 feet of muck; on a bench claim nearly 1,000 feet west of Candle Creek a 33 -foot hole put down with a thawer gave the following section:

Section near Candle Creek, Alaska.

Muck

Slide consisting of yellowish and reddish quartz sand with

" chicken feed" (finely ground schist)

Sand 
To the south another hole afforded a second section:

Section near Candle Creek, Alaska.

Turf and slide

Feet.

Gravel with some rounded quartz pebbles reaching a diameter

of 6 inches

6-8

Bed rock, a yellowish gravelly clay with angular pieces of lava.

No pay streak is known on Candle Creek, and the gold is, as the miners say, "spotted" or irregularly distributed on the bed. The presence of rich gravels just below the mouths of the tributaries from the west leads to the general belief among the miners that the gold comes from the country west of Candle Creek, and in consequence only on that side have the bench claims received much attention.

The best pay is said to come from the high parts of the rim and from the upper 4 inches of the blue-clay bed rock. The gold in the clay is not saved, owing to its fineness and the difficulty of separating it. One of the most successful claim owners told the writer that, where gravels are not worked on a large scale, probably not over 70 per cent of the total values are recovered, owing to the crude methods employed. The gold is usually flattened and black, so that when cleaning out the boxes miners are often seen biting a nugget to make sure that it is gold and not one of the "iron stones." Quartz is at time embedded in the larger nuggets, and gold is observed now and then in the form of fine veinlets through the "iron stones." One nugget weighing $\$ 62.10$ and a second weighing $\$ 36$ have been taken from the creek.

Black sand is unknown in the clean ups; pyrite and a few small pieces of rutile which occasionally have been mistaken by the miners for tin ore are the heavy minerals associated with the gold; it is not considered a favorable sign when the iron stones fail.

Reliable estimates of the quantity of gold produced on the creek since its discovery in 1901 are not easily secured, since many miners are reticent about making any statements of the production of their claims, but it is probable that the amount is not far from $\$ 325,000$.

From Willow Creek to within one-half mile of Candle, a distance of nearly 8 miles, almost the entire channel has been worked over by a narrow cut averaging 8 or 9 feet in width, and the more easily and cheaply mined gold has been taken out, in consequence of which the miners now believe that the future of the creek depends on the value of its bench claims (Pl. XIII, $B)$. Up to the present time only one of these has been shown to possess gravels of sufficient value to pay for removing the overlying moss and slide by the methods now employed. None of the dozen or more holes thawed down during the season of 1903 failed to disclose gold in quantities up to 25 cents per pan, but lack of water and high cost of coal are discourag- 


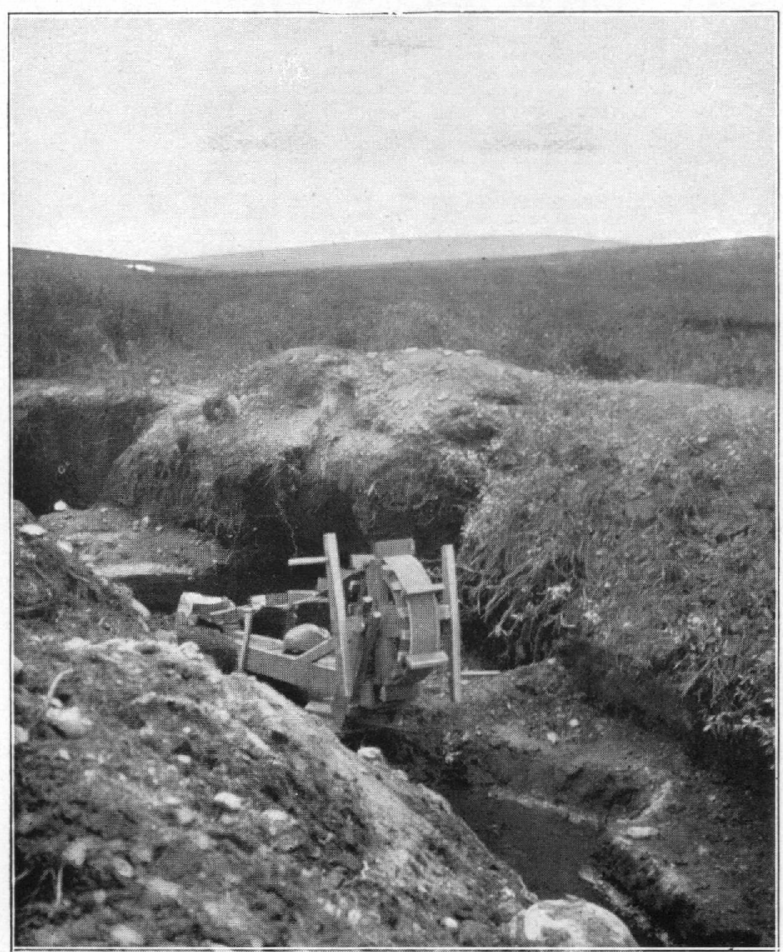

A. CHINA PUMP ON CANDLE CREEK.

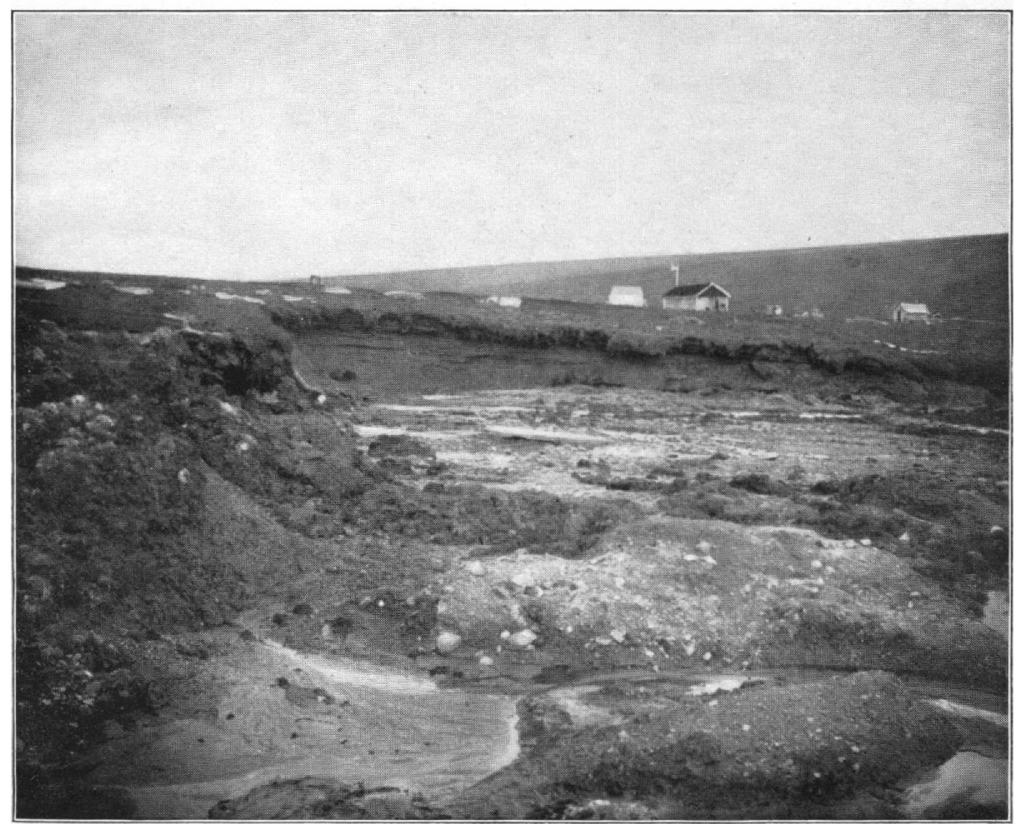

3. BENCH CLAIM ON CANDLE CREEK, SHOWING 12 FEET OF ICE ABOVE THE GRAVEL. 

ing to the prospector. The universal use of the China pump ( $\mathrm{Pl}$. XIII, $A$ ) on the creek claims is a necessary result of the low grade of the stream, which does not permit the miner to employ a bed-rock drain for keeping the pits dry. These pumps are usually driven by hand, and require the services of one or two extra men in addition to the usual force. In one case a small gasoline engine replaced the men at the pumps; in another case a steam engine was used to supply water for the sluice boxes and to clear the pit.

The only other machines employed on the creek are the boilers (PI. $\mathrm{XIV}, A$ ) used in thawing the bench gravels. These ordinarily supply steam to four points at about 60 pounds pressure, and are fired with coal hauled from Chicago Creek, on Kugruk River, or more generally with Wellington coal delivered at Kiwalik, from which point it is brought to Candle by a small boat and then freighted to the camps. During the summer of 1903 the cost of Wellington coal laid down on the claims was $\$ 83$ a ton, that of the native coal $\$ 40$. The native coal is brought over the snow in the winter time and is widely used in cooking and for heating purposes, but on account of its inferior character and the large percentage of ice which it contains when first mined, is less desirable for boiler use than Wellington coal even when the difference in cost is considered. During the excitement of the first season, when everyone was endeavoring to make the most of the time left before winter should stop the work, the rocker was used generally on the creek, and is now employed at times, especially for testing bench gravels while the holes are being thawed down.

Work on this creek has been carried on under many difficulties. Although more easily reached than many of the other Alaskan fields, the short season, combined with the high freight rates and great cost of fuel and supplies, has had the effect of retarding considerably the development of the region. In addition to these disadvantages the cost of mining is increased by the low grade of the stream and the necessary use of the pump, and on some claims by lack of water for sluicing during a large part of a season already too short.

While gold is evidently present on some of the benches, the question of a water supply with suflicient head and volume for the employment of some economical method of working the gravels is a serious one.

BUCKLAND RIVER BASIN.

Bear Creek.-Bear Creek, the most easterly of the gold-producing streams in the Fairhaven mining precinct, is tributary to the western fork of Buckland River. By the overland trail, followed in carrying provisions and tools to the camps, the distance from Candle to the head of Bear Creek is about 40 miles; to the first gold diggings 
the distance is 6 or 8 miles more. This trail is the one almost always followed by the prospectors. From its headwaters on the west to the point where it joins the Buckland on the east the creek follows a channel about 17 miles long. Its course describes a semicircle with the convex side turned toward the south, thus inclosing on the north a small area of hilly country drained by three small tributaries, one of which is the chief gold producer of the region. This stream, Sherdon Creek, and Cub Creek, on the south, are the only tributaries of interest at present.

The upper part of Bear Creek and also the small creeks flowing into it from the west have cut deep, narrow valleys in the bare eruptive complex of granites, andesites, and lavas forming the divide between the drainages of Kiwalik and Buckland rivers, but toward the east, in the lower course of the stream, the valley broadens and its slopes are covered with a good growth of spruce timber. Mica-schist is said not to be found on the creek, although mica does appear in the sands and gravels, which are composed largely of eruptive material, and on some of the bench claims reach a thickness of 20 feet, with several feet of muck overlying. In places on the creek a considerable quantity of a heavy, red, cherty rock remains in the boxes with the gold and is a source of some annoyance to the miner. This is especially true on Cub Creek. On Sherdon and Bear creeks the gold is mostly on bed rock, differing in this respect from that on Cub Creek, where it is found throughout the whole thickness of the 2 feet of stream gravel; on the other hand, gold from Bear and Cub creeks is light and flaky, while that from Sherdon is heavy. All the gold is bright yellow in color, assaying $\$ 19.20$ to the ounce. A little "white iron" pyrite is present, and also an abundance of black sand, which is entirely removed by the magnet. The greatest trouble in sluicing is given by the red rock, because it is very heavy and sticks in the riffles of the sluice boxes.

During the season of 1903 about 40 men were at work on Bear Creek and its tributaries, but not all of them succeeded in making wages, since, with the high cost of freighting ( 20 cents per pound from Candle), only the richest gravels have been profitable. The total output of the creeks is said to be about $\$ 10,000$.

\section{KUGRUK BASIN.}

Dixie Creek.-The various streams which empty into Kugruk River were prospected to a greater or less extent during the summer of 1901-2 without offering much encouragement in return for the labor expended. As a result of this, practically nothing was done on any of the streams belonging to the Kugruk drainage system during the season of 1903 , with the exception of Dixie Creek, a tributary to 


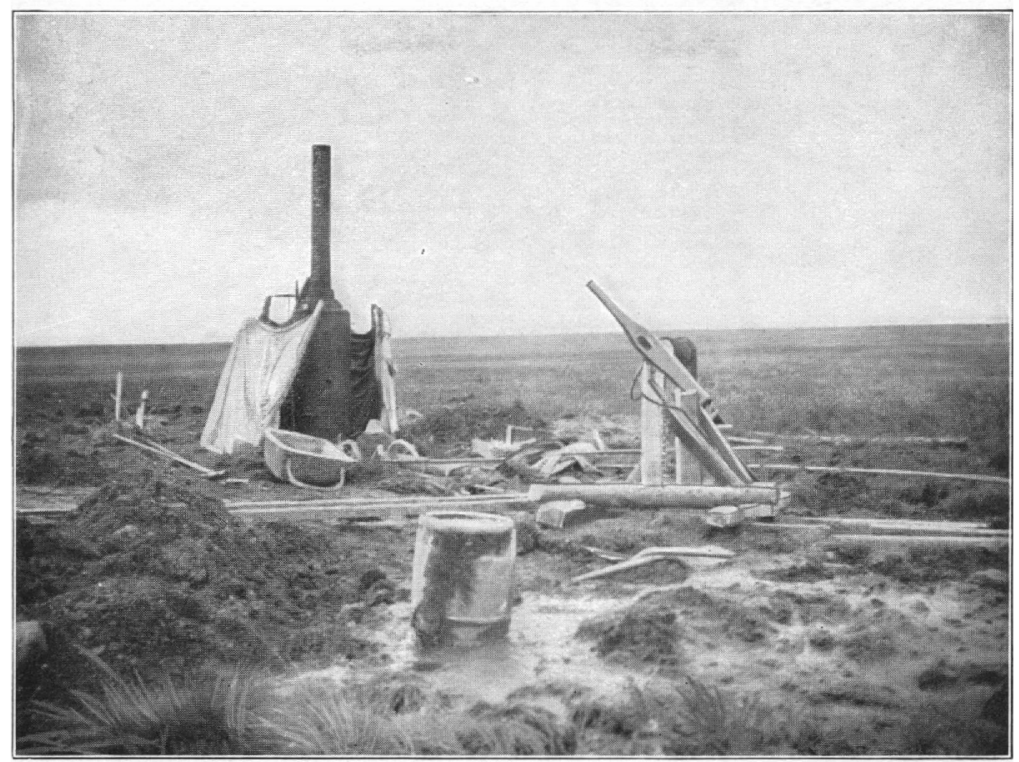

A. BOILER FOR THAWING FROZEN GRAVELS ON CANDLE CREEK.

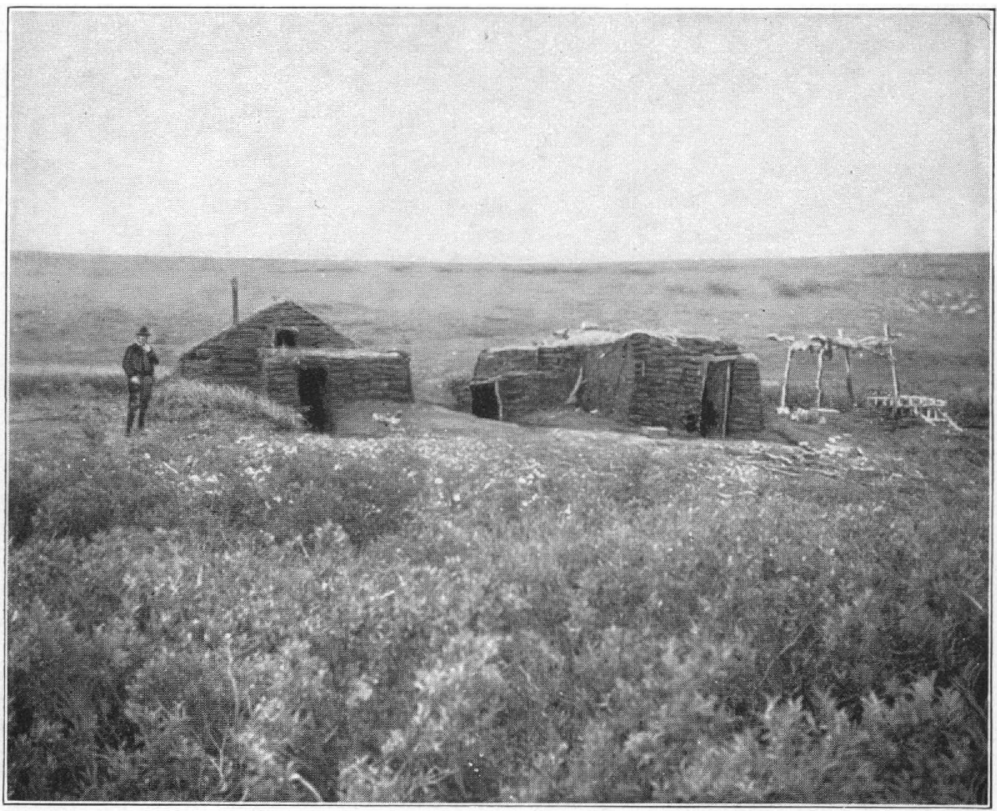

B. WINTER CABINS ON INMACHUK RIVER 

Independence Creek, where two men have worked the greater part of the summer and report good wages.

Alder Bearh.-There still remains to be described one other occurrence of gold in the Kotzebue field-that of the beach sands near Alder Creek-about midway between Kiwalik and the mouth of Kugruk River. This locality was visited by Mr. Walter C. Mendenhall in 1901, and the following description is quoted from his report. ${ }^{a}$ "Beach diggings of limited extent have been carried on near the mouth of Alder Creek, and are reported to yield $\$ 8$ or $\$ 10$ per day to the man. The gold here is fine and is evidently derived immediately from the dark-gray schists that form the bluffs back of the beach. Bed rock is reached at a distance of about a foot under the shingle of the beach, and the gold is taken from its surface. Some threads of wire gold are seen among the washings." The output for the years 1902 and 1903 was about $\$ 12,000$.

\section{SOURCE OF THE GOLD.}

There can be little doubt that the gold of Alder Beach, Candle Creek, and the Inmachuk region has had very much the same history as that held to be true for the other deposits of Seward Peninsulathat it is of local origin and is a concentration from an original supply widely disseminated in small quartz veins and stringers and impregnated zones of the bed rock. This is shown by both the character and the occurrence of the gold itself.

Here as elsewhere the gold placers are of limited extent and irregular distribution, so that, while some creeks have been supplied with rich deposits yielding large returns to the miner, others in the immediate vicinity have shown no gold whatever, or at most only a trace. No deposits such as those north of Dexter Creek near Nome, which belong to an older drainage system than the present one and have been called " high bench deposits" by Brooks, are known to be present in the Kotzebue field, although it is by no means certain that none such exist.

The finding of nuggets with attached or included quartz or schist and the identity of the gold-bearing gravels with the outcrops which are now seen at many points along the valleys make it very probable that the gulch deposits have their source in the rocks of the drainage basin in which the present streams now flow. The gravels carrying values are all derived from the weathering of rocks that have been subjected to intense pressure, heat, and other influences of such a nature as to change entirely their original character and to fill them with an intricate network of small quartz veins and

a Mendenhall, Walter C., Reconnajssance from Fort Hamlin to Kotzebue Sound, Alaska : I'rof. Paper U. S. Geol. Survey No. 10, 1902, p. 51.

Bull. $247-05$ x- -5 
lenses, known in some cases to be gold bearing. 'The concentration of the heavier and more indestructible metal, due to the action of surface waters on the vast amount of material derived from the decomposition of these gold-bearing schists, amounting to a vertical thickness of hundreds and possibly thousands of feet, has, without much doubt, given rise to the rich gold deposits now found in the gravels. So constant is the association of the gold with the schists that the prospectors refuse to spend time in the search for gold where schist is not found. It is a fact worthy of note that up to this time there is but one auriferous quartz vein on the peninsula that is proving itself to be a mine. Mr. Brooks says: "The chief reason why more rich veins are not found in the region is because much of the gold was widely disseminated in snuall quartz stringers and in impregnated zones of the bed rock. It is not derived from a mother lode, but in the course of the destruction of the bed rock the gold thus widely disseminated in small veins was concentrated in sands and gravels." a

It is further probable that the gold in nearly every case has traveled but a relatively short distance from its original source. The rough, unworn appearance; the absence of any large amount of fine, bright, flaky gold; the occurrence of wire gold in one instance, and the presence of considerable quartz in the nuggets all go to establish this conclusion.

\section{SUMMARY.}

The gravels of the placer-gold field south of Kotzebue Sound have yielded about $\$ 415,000$ in the three years beginning with the discovery of gold in 1901 and ending with the season of 1903 .

The chief producing streams, in the order of their output during those years, are Candle Creek and Inmachuk River. Candle Creek gravels are the richest that have yet been discovered in this field and have been the most vigorously exploited, with the result that about three-fourths of the total output of the region has come from this one stream. In the Inmachulk region gold has been found in greatest amount on the Inmachuk itself, but has also been obtained from several of the tributaries, especially Old Glory and Hannum creeks. Cunningham Creek, Nelson Gulch, American Creek, and Pinnell River have produced still smaller quantities. In addition to these localities Bear Creek, a tributary of Buckland River, and Alder Beach, nearly 10 miles west of Kiwalik, have a small gold output, amounting in all to over $\$ 20,000$, about equally divided between the two.

The gold-bearing gravels, with the exception of those on Bear Creek, are of local origin and are derived from the decomposition of

a Brooks, Alfred H., Reconnaissance in the Cape Nome and Norton Bay Regions, Alaska, In 1900, U. S. Geol. Survey, 1901, p. 142. 
schists, through which the gold is disseminated in fine stringers and veins of quartz. The concentration of the heavy metal has been brought about by the action of water currents, which have separated it from a vast amount of rock material and deposited it where now found.

\section{COAL.}

Coal has been reported from a number of localities on Seward Peninsula, but, although present in workable quantities in a few places, has never yet been of such a quality as to replace the imported coals. At the point where Kugruk River makes the big bend to the west, it is joined by a small stream known as Chicago, or Granite, Creek, which drains the area toward the northeast, and at one time was regarded as a favorable locality for gold prospecting. Placer and bench claims were located on the creek, and not a little work was done. While examining the gravels of the lower part of the channel, small pieces of coal were found by some of the prospectors, who traced them to their source at a point on the stream a mile northeast of the mouth, and located the ground for mining purposes. During the last winter these men, Messrs. Peterson, Roust, and Nelson, drove a slope into the deposit for a distance of nearly 200 feet, and took out coal which was used on the creek more or less last summer (1903). A crosscut of co feet was made in the deposit without discovering the walls, and the owners believe that the coal, which is of lignitic character with now and then a bright-yellowish spot of amber, occupies a basinshaped depression in the country rock. The entrance to the slope is always covered with a coating of ice, and as far as exposed the coal is frozen solid, a condition that proves to be a great objection to its use, since for good results it must be allowed to stand and thaw during the summer. The coal checks and crumbles badly after being mined, but burns easily, with a bright flame, and leaves a small amount of white ash, like wood ash. ${ }^{a}$ Prospectors regard two tons of it as equal to about one ton of Wellington coal, a ratio also expressed by the difference in cost.

Coal is frequently seen in the gravels of Kugruk River above Chicago Creek, and a second bed was discovered on French Creek, one of the smaller streams of the upper Kugruk drainage. This bed has never yet been prospected, but is reported to be smaller than the one just described.

As to the future value of these beds it is difficult to form any idea, but under the present conditions it seems that there may be a limited demand for the coal in spite of its inferior quality as long as gravels are being worked on the near-by creeks. For cooking purposes it is superior to wood, and it can be hauled over the snow in winter with little difficulty, but as a steam coal it has not been very successful.

a The following analysis of Chicago Creek coal was made in the laboratory of the Geological Survey : Fixed carbon, 33.58; volatile comhustible matter, 38.15 ; molsture, 24.92 ; ash, 3.85 ; sulphur, 0.68 . 


\section{GENEIRA $\triangle$ CONDITIONS.}

TRAILS.

The camps of the gold field described above may be reached from Nome either by overland trail or by the water route through Bering Strait and the Arctic Ocean into Kotzebue Sound. Both routes are used, and each has certain advantages of its own not possessed by the other. Kotzebue Sound was frequently visited by vessels long before the discovery of gold on the creeks, and this method, all things considered, is still the most practicable way by which miners can obtain provisions and the other necessary supplies.

The distance from Nome to the town of Kiwalik, measured in a direct line between the two places, is very nearly 150 miles, but the distance actually traversed in going overland from one place to the other is considerably greater than this, owing to the indirectness of the trails through a region sometimes mountainous and always wet. A distance of more than 300 miles must be traveled when the sea route is chosen, but the time required is less and the difficulties of the crosscountry journey are avoided. This method is, of necessity, used only during the summer months, since throughout the greater part of the year ice puts an end to all navigation. The open season begins about the middle of July, when the ice of the sound melts, its protected position preventing it from being reached and broken up earlier in the year by the storms of the outside sea. Navigation closes again about October 10, when the last boats leave Deering and Kiwalik to avoid the possibility of being frozen in for the winter. However, there is generally a week or more of good weather after that date. Deering and Kiwalik may thus be frequently reached by water during three months in the year, since the two small steamers running between Nome and Kotzebue Sound make regular trips twice each month with mail and freight.

The overland trails are used by the miners who wish to take in supplies over the snow or who desire to be on the creeks early in the season, and also by the men who carry the mails after the closing of navigation. Of the two principal trails, that used by the mail carriers is the more direct, but is not much traveled in summer. It starts from Council, ascends Fish River to a small tributary just north of Mosquito Creek, crosses over the divide to Death Valley, on the head of Tubutulik River, and reaches the Koyuk by way of a narrow mountain pass about 1,200 feet above sea level, and Timber Creek. After crossing Koyuk River and Big Bar Creek this trail continues up First Chance Creek and over a low divide to the head of Gold Run, thence northward along Kiwalik River to Candle. The northern half of the trail is not difficult for pack horses in the summer time if the traveler keeps on the ridges, where the moss is not so widely spread and the harder ground affords better footing. 
The second route reaches Lanes Landing by way of Nome River and Salmon Lake trail from Nome or by way of Teller and Marys Igloo. A wagon road leads from Lanes Landing to Quartz Creek. From Quartz Creek one travels northeast around the lowlands of Kuzitrin and Noxapaga rivers to Turner Creek, and thence along a low rounded ridge to Aurora and Eldorado creeks. At Eldorado Creek the trail turns eastward, crosses the head of Placer and Esperanza creeks to Goodhope River, and then follows the Cottonwood to Trail Creek, which heads against the Inmachuk.

With horses the northward detour from Turner Creek is necessary in order to avoid the lava-covered and nearly impassable country along the east fork of the Noxapaga. This trail is the one usually followed by prospectors starting from Nome in summer or in the springtime after the melting of the snow has put an end to the use of sleds, and, while perhaps somewhat longer than the trail from Council, does not cross as much rough ground.

The water route, when conditions permit its use, is so much quicker and easier that it is to be preferred by those who wish to go into the country themselves or who have freight to be taken in. One great abjection to it lies in the lateness of the season when the first boats enter the sound, since conditions on the creeks are favorable for some work before the middle of $\mathrm{July}$.

There is still a third route from the south to the north side of Seward Peninsula, which, however, is rarely used. Starting from Norton Bay at the mouth of Koyuk River, the trail follows the stream to the northward about 15 miles, then ascends the east fork and crosses over the divide to the head of the west fork of Buckland River. This furnishes a comparatively easy method of reaching Bear Creek from Norton Bay, but is not a practicable road to Kiwalik or Inmachuk rivers. As has already been stated, the Buckland does not afford a favorable means of reaching Bear Creek from the north. The overland trip from Candle to Bear Creek can be made with pack horses in from twenty-four to twenty-six hours, while on the other hand it required in one case sixteen days of hard work to take a boat load of supplies up Buckland River from Kiwalik to Cub Creek, a small tributary of the Bear. Throughout Seward Peninsula winter is the chosen time for traveling and for freighting supplies where boats can not be used, and, as a result of this, the trails are obscurely marked or more often do not show at all in summer. Some bad stretches in the more frequently traversed roads near Lanes Landing are marked with flags, which indicate the less difficult crossing places, but farther toward the east the traveler is usually under the necessity of choosing his own trail and must rely on his own experience and judgment in doing so. 
MAIL SERVICE.

The ease with which Deering, Kiwalik, and Cape Blossom, the towns on the shores of Kotzebue Sound, can be reached by boat during part of the year has proved greatly to their advantage in the matter of communication with the outside world.

After the opening of navigation in the spring the miners of the Kotzebue field receive mail regularly twice a month as long as the sound is open, but from the closing in of the ice until the ground is covered with snow suitable for sledding no mail is received on the creeks. In the winter just passed, 1902-3, it was not until after the 1st of January that the condition of the ground permitted the regular mail service to be resumed again and letters to be delivered every fifteen days by carriers who crossed the snow-covered hills with dog teams. Two men are employed in this work; they carry only firstclass mail matter, and throughout the winter each of them makes one monthly round trip as far north as Point Blossom. Mail service is again interrupted for a short time by the spring thaw and disappearance of the snow, thus making in all four months of the year during which communication with the rest of the world is nearly suspended.

\section{ECONOMIC CONDITIONS.}

The Kotzebue field, like the Nome field, possesses one great advantage over many of the other Alaskan gold regions in that the sea affords a less expensive means of transportation than must necessarily be employed in the new and undeveloped parts of a country remote from railroads, large rivers, or good trails.

While the absence of timber and underbrush removes one of the greatest difficulties encountered in the use of pack horses, that method of carrying freight has never been looked on with favor because of the scarcity of horses and the great expense of keeping them through the long winter of a country where no feed is raised. Good grass is found in all the valleys and may be expected in abundance from about July 1 till the early frosts in the middle of September. After September 20 it is not safe to depend on grass alone for feeding horses, and if they are to be used either earlier than July 1 or later than September 20 hay and oats should be provided. So high is the cost of these that some men owning horses have preferred to send them out to Seattle and bring them in again in the spring rather than to buy feed. Not infrequently men who have wintered in Nome or have spent the time in work on the creeks carry in their summer outfits over the snow with dogs just before the spring break-up, a plan which at that season of the year is no more expensive than steamship transportation later on.

The absence of timber is a serious problem when considered from the standpoint of fuel supply, for it will be only a short time till 
the scanty growth of willows along the streams will be exhausted. Even now a good percentage of the larger ones have been elt. Candle is somewhat more fortunate than the camps to the west, in that several of the streams in the upper part of Kiwalik Valley are lined with a sparse growth of spruce, which furnishes material for building as well as for fuel. The trees are cut in winter or spring and are floated down the river on the high water from the melting snow.

At the head of Kugruk River, also, small scattered spruce trees are found, from which some wood has been cut for use on the claims or has been hauled by sleds as far as the Inmachuk. The need of plenty of good fuel is the greater when the frozen character of the gravel is considered, since without water or the proper location of ground for the use of water when there is an abundant supply at hand, there remains no way of loosening the gravel other than by thawing. All deposits when covered with moss are frozen, but the depth of the frost is not now known, although the slope in the coal on Chicago Creek is said to have reached a depth of nearly 100 feet below the surface without finding thawed ground. One of the greatest difficulties under which the prospector works in this region is the shortness of the season. Very little can be done on any of the claims before July 15, and in some instances men coming in from the outside by boat have been unable to enter the sound till later than that date. In the summer just over, practically all sluicing was ended by September 20 , and few men remained on the creeks except those who were expecting to winter there and take out a dump to be washed with the water from melting snows in the spring. It would therefore seem that at the outside not more than two and one-half or three months of weather suitable for sluicing can be expected, and that this amount should be looked for only in a most favorable season. Candle Creek labors under the additional disadvantage of low grade and small water supply, which has to this time prohibited the use of economical methods of mining depending on head or abundant water. On the successful solution of this problem will depend the future development of the Candle bench claims in case they prove to be of value.

\section{CLIMATE.}

The climate of Seward Peninsula, owing to the influence of the Arctic Ocean on the north and of Bering Sea on the south, is not subject to the extremes of temperature met with in the interior. For the same reason, however, cloudy and wet weather in summer and snows in winter are more frequent.

A summary of the very imperfect meteorologic records kept at various points on the peninsula was made by Collier in $1901,{ }^{a}$ which

a Brooks, Alfred H.; Richardson, dieorre B. : Collier, Arthur, and Mendenhall, Walter C., Reconnaissances in the ('ape Nome and Norton Bay Regions, Alaska, in 1900, I:. S. Geol. Survey, 1901, p. 159. 
gives the maxinum reorded temperature for Kotzebue Sound as $81^{\circ} \mathrm{F}$. and the minimum as $-43^{\circ} \mathrm{F}$. The maximum temperature known to the writer in 1903 was $81^{\circ} \mathrm{F}$. This was observed in June at Nome and may have been influenced by radiation from the beach sands. During the remainder of the season the thermometer used in taking olservations did not reach a higher point than $65^{\circ} \mathrm{F}$. The summer is warm enough to be confortable, but so short that snowclrifts often remain from one winter to the next on the protected sides of steep hills. Vegetables which mature quickly may be grown with proper care, and, in fact, were seen at a few places. The last summer was drier than is usual in the Kotzebue Sound region, but there was sufficient water for sluicing purposes on most of the creek claims. The work of the Survey party was interfered with very little by rain or by any climatic condition till the early frosts came, although for several days in August smoke from burning tundra made topographic mapping almost impossible. It may not be generally known that the Alaska criminal code, chapter 3, section 61, makes the starting of tundra fires an offense punishable by imprisonment for three months to one year or by a fine of from $\$ 50$ to $\$ 500$.

The last few weeks of the summer season, including the end of September and the first of October, are often the most pleasant of the year, the air being clear and invigorating and, best of all, the mosquitoes no longer annoying one; only those who have experienced these pests in Alaska can appreciate the discomfort caused by them. In some seasons the cold comes quickly after such a period of fine weather, the sound fills with slush ice, and the rivers may be covered with thick, solid ice in a night. Temperatures as low as - $50^{\circ} \mathrm{F}$. may be reached for a few days in winter, but the cold is not regarded as especially uncomfortable unless accompanied by high winds. At such times it is exceedingly dangerous to be out, and the experienced prospector who is so unfortunate as to be caught out crawls into the fur sleeping bag, from which he never parts while traveling, calls his dogs around him, and waits for the storm to cease, even if it requires several days. Winter is the traveling season throughout Alaska, and is especially so in the Kotzebue country, where the sound is open during only three months out of the twelve. The accompanying table of temperatures, which was kept by Mr. Hill, gives observations taken three times a day. It was attempted to take these readings at regular hours, but this was not always possible on account of the conditions of the work, and the differences in time may be as much as two hours in some cases. It was considered best to give the readings as they were taken and withont any attempt to make out daily or monthly averages, which do not convey much information where observations are not kept at fixed stations and at definite hours. 
Temperatures taken by Geological Survey party in Seward Peninsula in 19h.

\begin{tabular}{|c|c|c|c|c|c|c|}
\hline \multirow{2}{*}{ Place. } & \multirow{2}{*}{ Date. } & \multirow{2}{*}{ A. $M$. } & \multirow{2}{*}{ M. } & \multirow{2}{*}{ P. M. } & \multicolumn{2}{|r|}{ Conditions. } \\
\hline & & & & & Wind. & Weather. \\
\hline & & ${ }^{\circ} F$ & ${ }^{\circ} F$ & $\circ F$ & & \\
\hline \multirow[t]{7}{*}{ Nome . } & June 21 & 61 & 81 & 80 & & Fair. \\
\hline & June 22 & 82 & 65 & 56 & & Do. \\
\hline & June 23 & 62 & 64 & 62 & $\cdots$ & Do. \\
\hline & June 24 & 62 & $\ldots$ & 45 & E. & Do. \\
\hline & June 25 & 61 & 63 & 54 & ...... & Do. \\
\hline & June 26 & 61 & 62 & 51 & W. & Do. \\
\hline & June 27 & 48 & 56 & $\ldots$ & W. & Cloudy. \\
\hline Dry Creek & June 28 & 46 & $\cdots$ & 47 & S. & Do. \\
\hline \multirow[t]{2}{*}{ Nome River .......... } & June 29 & 42 & 54 & 39 & $\ldots$ & Fog in a. $\mathrm{m}$. \\
\hline & June 30 & 56 & 52 & 43 & SW. & Fair. \\
\hline \multirow[t]{3}{*}{ Salmon Lake . } & July 1 & 42 & 53 & 41 & W. & Partly cloudy. \\
\hline & July & 51 & 52 & 41 & $\mathrm{SE}$. & Cloudy. \\
\hline & July & 45 & 45 & 45 & SE. & Partly cloudy. \\
\hline Kruzgamepa River . .... & July & 45 & $\cdots$ & 48 & E. & Cloudy. \\
\hline \multirow{3}{*}{$\begin{array}{l}4 \text { miles south of Cotton- } \\
\text { wood road house. }\end{array}$} & July & 56 & 52 & 52 & sw. & Rain. \\
\hline & July & 55 & 56 & 50 & sW. & Do. \\
\hline & July & 48 & $\ldots$ & 42 & S. & Cloudy. \\
\hline $\begin{array}{l}1 \text { mile north of Cotton- } \\
\text { wood road honse. }\end{array}$ & July & 54 & & 41 & NE. & Rain. \\
\hline Lanes Landing . . ....... & July 9 & 54 & 58 & 43 & & Partly cloudy. \\
\hline \multirow[t]{2}{*}{ Coffee Dome } & July 10 & 47 & 62 & 52 & S. & Fair. \\
\hline & July 11 & 46 & 56 & 58 & s. & Cloudy. \\
\hline \multirow[t]{2}{*}{ Dall Creek . } & July 12 & 46 & 49 & 44 & NW. & Rain. \\
\hline & July 13 & 48 & 48 & 45 & NW. & Do. \\
\hline \multirow[t]{2}{*}{ Delome Creek . . . . . . . . . . } & July 14 & 49 & 47 & 46 & NW. & Clondy. \\
\hline & July 15 & 45 & 58 & 49 & SE. & Fair. \\
\hline Turner Creek .......... & July 16 & 58 & 57 & 54 & SE. & Cloudy. \\
\hline \multirow[t]{2}{*}{ Aurora Creek } & July 17 & 53 & 56 & 49 & & Fair. \\
\hline & July 18 & 46 & 49 & 47 & & Do. \\
\hline \multirow[t]{3}{*}{ Eldorado Creek } & July 19 & 55 & 56 & 45 & NNW. & Fog and clouds \\
\hline & July 20 & 60 & & $\cdots$ & & Fair. \\
\hline & July 21 & 62 & 60 & 55 & SSW. & Do. \\
\hline \multirow[t]{2}{*}{ Berry Creek } & July 22 & 45 & ...... & 59 & & Do. \\
\hline & July 23 & 61 & 65 & 60 & & Smoke. \\
\hline Goodhope River ....... . & July 24 & 64 & 69 & 60 & & Showers. \\
\hline \multirow[t]{5}{*}{ Thomas Creek .......... } & July 25 & 60 & 62 & 58 & & Fog. \\
\hline & July 26 & 54 & & $\ldots$ & & Fair. \\
\hline & July 27 & 64 & $\cdots$ & 51 & & Rain. \\
\hline & July 28 & 59 & 62 & 52 & $\mathbf{E}$ & Fair. \\
\hline & July 29 & 63 & 6.5 & 63 & SSE. & Clonds and rain \\
\hline
\end{tabular}




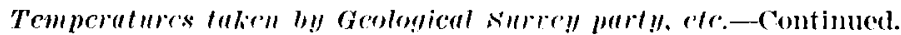

\begin{tabular}{|c|c|c|c|c|c|c|}
\hline \multirow[b]{2}{*}{ Place. } & \multirow[b]{2}{*}{ Date. } & \multirow[b]{2}{*}{ A. $\mathbf{M}$. } & \multirow[b]{2}{*}{ M. } & \multirow[b]{2}{*}{ P. M. } & \multicolumn{2}{|r|}{ Conditions. } \\
\hline & & & & & Wind. & Weather. \\
\hline & & $\circ H^{\prime}$ & $\circ H$. & ${ }^{\circ} \mathrm{F}$ & & \\
\hline Goodhope River. & July 30 & 54 & 59 & 53 & & \\
\hline \multirow[t]{3}{*}{ Eureka Creek . . } & July 31 & 44 & 53 & 52 & SSE. & Rain. \\
\hline & Ang. 1 & 45 & 58 & 48 & W. & Fair. \\
\hline & Aug. & 51 & 54 & 52 & NNE. & Rain. \\
\hline \multirow[t]{2}{*}{ Fish River.........} & Aug. 3 & 51 & 54 & 48 & SSW. & Do. \\
\hline & Aug. 4 & 52 & $\ldots$ & 55 & SSE. & Cloudy. \\
\hline \multirow[t]{2}{*}{ Butte Creek. } & Aug. 5 & 58 & 61 & 52 & SSE. & Do. \\
\hline & Aug. 6 & 48 & 60 & 47 & S. & Fair. \\
\hline Nugnugaluktuk River & Aug. 7 & 56 & 62 & 61 & NNE. & Partly cloudy. \\
\hline \multirow{3}{*}{$\begin{array}{l}\text { South Fork of Nugnug- } \\
\text { aluktuk River. }\end{array}$} & Aug. 8 & 52 & 62 & $6 \tilde{5}$ & & Fair. \\
\hline & Aug. 9 & 61 & .... & 66 & NNE. & Do. \\
\hline & Aug. 10 & 62 & 63 & 60 & - . . & $\begin{array}{l}\text { Cloudy } \\
\text { smoky. }\end{array}$ \\
\hline \multirow[t]{3}{*}{ Devil Mountain } & Aug. 11 & 59 & 64 & 61 & ENE. & Do. \\
\hline & Aug. 12 & 44 & 50 & 49 & E. & Rain. \\
\hline & Aug. 13 & 50 & 57 & 51 & $\ldots$ & Cloudy. \\
\hline \multirow[t]{4}{*}{ West of Devil Mountain. } & Aug. 14 & 50 & 51 & 51 & ESE. & Rain. \\
\hline & Aug. 15 & 48 & 52 & 53 & S. & Cloudy. \\
\hline & Aug. 16 & 53 & 54 & 48 & NE. & Do. \\
\hline & Aug. 17 & 50 & 56 & 51 & & Do. \\
\hline East of Slate Mountain & Aug. 18 & 45 & 49 & 45 & NNW. & Rain. \\
\hline 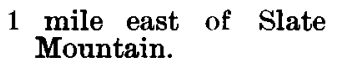 & Aug. 19 & 48 & 50 & 48 & N. & Do. \\
\hline Humboldt River . . . . . . . & Ang. 20 & 42 & 47 & & NNE. & Cloudy. \\
\hline Goodhope River... & Aug. 21 & 47 & 55 & 41 & & Fair. \\
\hline Cripple River. . . . . & Aug. 22 & 38 & 54 & 54 & & Do. \\
\hline Clifford Creek ... . & Aug. 23 & 45 & 55 & 46 & & Do. \\
\hline Reindeer Creek. & Aug. 24 & 38 & 46 & 43 & & Do. \\
\hline Hannum Creek & Aug. 25 & 41 & 50 & 43 & & Do. \\
\hline Sullivan Creek . & Aug. 26 & 41 & 44 & 41 & & Cloudy. \\
\hline Inmachuk River. & Aug. 27 & 43 & 50 & 42 & NNE. & Fair. \\
\hline \multirow[t]{2}{*}{ Deering . . . . . . } & Ang. 28 & 44 & 46 & 45 & & \\
\hline & Aug. 29 & 50 & 56 & 50 & & Clondy. \\
\hline Kngruk River & Aug. 30 & 49 & 50 & 47 & SE. & Do. \\
\hline \multirow[t]{2}{*}{ Willow Creek ......... } & Aug. 31 & 38 & 55 & 53 & W. & Partly cloudy. \\
\hline & Sept. 1 & 48 & 54 & 50 & s. & Cloudy. \\
\hline Chicago Creek ... & Sept. 2 & 52 & 60 & 53 & S. & Do. \\
\hline Minnehaha Creek . - & Sept. 3 & 49 & 57 & 54 & S. & Do. \\
\hline \multirow[t]{2}{*}{ Kiwalik ......... } & Sept. 4 & 46 & 60 & 51 & SE. & Fair. \\
\hline & Sept. 5 & 51 & 5 & 52 & & Rain. \\
\hline
\end{tabular}


Temperatures taken by Geological Survey party, etc.-Continued.

\begin{tabular}{|c|c|c|c|c|c|c|}
\hline \multirow{2}{*}{ Place. } & \multirow{2}{*}{ Date. } & \multirow{2}{*}{ A. $\mathbf{M}$. } & \multirow{2}{*}{$\mathbf{M}$. } & \multirow{2}{*}{ P. $\mathbf{M}$. } & \multicolumn{2}{|r|}{ Conditions. } \\
\hline & & & & & Wind. & Weather. \\
\hline & & $\circ F$. & $\circ F$ & ${ }^{\circ} F$ & & \\
\hline \multirow[t]{3}{*}{ Candle . } & Sept. 6 & 46 & 58 & 48 & & Clonily. \\
\hline & Sept. 8 & 45 & 62 & 53 & SSE. & Fair. \\
\hline & Sept. 9 & 39 & & & & Cloudy. \\
\hline \multirow[t]{2}{*}{ Near Buckland River. } & Sept. 10 & 44 & 48 & $\ldots$ & SSW. & Clouds and rain. \\
\hline & Sept. 11 & 53 & ...... & 46 & S. & Partly cloudy. \\
\hline \multirow[t]{4}{*}{ Branch Buckland River. } & Sept. 12 & 44 & 48 & 44 & SSE. & Cloudy. \\
\hline & Sept. 13 & 45 & 50 & 45 & SSW. & Rain. \\
\hline & Sept. 14 & 42 & 45 & 45 & & Do. \\
\hline & Sept. 15 & 46 & 54 & 47 & & Do. \\
\hline \multirow[t]{2}{*}{ Kiwalik River } & Sept. 16 & 29 & 55 & 45 & & Fair. \\
\hline & Sept. 17 & 42 & 46 & 31 & & Do. \\
\hline $\begin{array}{l}\text { West of Kiwalik Moun- } \\
\text { tain. }\end{array}$ & Sept. 18 & 33 & 43 & 35 & & Snow. \\
\hline \multirow[t]{4}{*}{ Koyuk River .......... } & Sept. 19 & 34 & 45 & 35 & N. & Fair. \\
\hline & Sept. 20 & 10 & 50 & 27 & & Do. \\
\hline & Sept. 21 & 25 & 50 & 39 & S. & Cloudy. \\
\hline & Sept. 22 & 21 & 42 & 31 & & Fair. \\
\hline \multirow[t]{3}{*}{ Noxapaga River } & Sept. 23 & 27 & 50 & 40 & & Do. \\
\hline & Sept. 24 & 34 & 44 & 22 & - . & \\
\hline & Sept. 25 & 29 & 43 & 36 & s. & Do. \\
\hline \multirow[t]{3}{*}{ Belt Creek . . . . . . } & Sept. 26 & 32 & 42 & 31 & & Do. \\
\hline & Sept. 27 & 33 & 39 & 33 & & \\
\hline & Sept. 28 & 25 & 43 & 26 & & Clondy. \\
\hline Canyon Creek . ... & Sept. 29 & 38 & 38 & 43 & S. & \\
\hline Eldorado River. ... . & Sept. 30 & 44 & 44 & 42 & S. & Rain. \\
\hline New Eldorado.......... & Oct. 1 & 40 & 42 & 42 & & Do. \\
\hline Nome. & Oct. $\quad 2$ & 43 & $4 \tilde{5}$ & 43 & & Do. \\
\hline
\end{tabular}

It may be of interest to consider a little more closely the results here given in connection with observations made by Survey parties in previous years. In 1900 the number of rainy days in the northwest part of the peninsula during the months of July, August, and September was about 35. In 1901 the number of rainy days in the northwest part of the peninsula during the same months was 36 . In contrast with these two records are to be noted the 21 days of rain experienced in 1903. It is thus seen that in so far as the number of rainy days is concerned the season was drier than the two previous seasons during which Survey parties have been at work in Seward 
Peninsula. In consecquence of this fact the topographic work was interfered with less by rain and more by smoke from tundra fires than would generally be expected in a given season. Comparatively little complaint was heard, however, of scarcity of water in the creeks.

\section{NATIVES.}

The natives of the Kowak River and Kotzebue Sound region were described by Lient. C. Cantwell ${ }^{a}$ in his account of the exploration of the Kowak (or Kobuk) in 1884 and 1885, and the opportunities for observation on the part of the writer do not enable him to add anything to that description.

Those met by the Survey party after leaving Nome were living on the coast of Kotzebue Sound in the neighborhood of the larger rivers, to which they come in the spring to trade, to hunt the seal, and to catch the salmon, which is dried and forms a most important article of food in summer and winter. 'The largest native village was near the mission and school at Deering. At Kiwalik, also, there were a number of families, and a few were seen at Candle. By the end of September, when the party was at Kiwalik, many of the natives had left the coast for their winter homes and others were on the point of doing so. In consequence not even an approximate estimate of their number at these places could be made. However, it is not large.

Natives have been employed by the miners in a few instances to shovel into the sluice boxes, but apparently the experiment did not result very satisfactorily and only one or two were seen on the creeks during the summer. Before the coming of the prospector, when the trader or whaler was the only visitor, the Eskimo was dependent very largely on the resources of the country for his food and clothing. These were furnished in part by the caribou, but this source was supplemented in various ways; in winter he snared the ptarmigan and Arctic hare; in spring and early summer he killed the seal and walrus; later he caught and dried fish for winter use and hunted for geese and ducks. With the advent of the miner he learned new ways of living; his requirements were increased and he is becoming more and more dependent on the white man. For flour and other forms of white man's food he trades skins, fish, and the native coat (parka) or boots (mukluks). In summer most of the men and many of the women wear the white man's clothing, but this is given up for, or supplemented by, the warmer skin garments in winter. At present the summer house is ordinarily a tent, such as is used by the prospector; in winter the coast is deserted and the winter house is built in some locality where game, especially ptarmigan, is plentiful.

a Cantwell, Isieut. J. C., Craise of the Corwin in the Arctic Ocean, 1884 and 1885. 
These are caught by planting willows in the snow and placing snares in such a position that the birds must spring them as they pick the buds from the twigs. The introduction of the reindeer by the Government seems to be a very wise plan, since it furnishes food and clothing as well as a means of travel, and since the game on which the native is largely dependent is continually becoming scarcer owing to the white man's presence and the improvement in the weapons used in hunting. Like the deer, the seal furnishes clothing as well as food; large quantities of the oil are used, while boots, the coverings for boats, and many other articles are made from the skins.

The native is not quarrelsome except when under the influence of alcoholic drink, for which he has a great fondness and for which he will exchange any of his possessions. Its sale is strictly forbidden by the Government, but the enforcement of the law is difficult, and is not always successfully accomplished.

\section{FISH AND GAME.}

Large game is now almost extinct on the peninsula ; a few caribou, not more than 12 or 15 , were observed by members of the party in the course of the field work, 3 of which were seen in the upper part of the Koyuk Valley, the others in the Devil Mountain region. That caribou were plentiful at one time is evident from the great number of antlers scattered over the tundra and the heaps of bones near old, deserted native igloos or houses. In passing from one feeding ground to another they followed permanent well-beaten trails along the crests of the ridges, where good traveling was to be had and a better opportunity was afforded to detect any danger at a distance. Bears are rarely seen in the Kigluaik Mountains, but are said to be rather numerous in the wooded country of Buckland River Valley; it is not unusual for the prospector to find them fishing in the shallow waters on sand bars. The flesh is eaten in the early spring, but is too strong to be good after the fish begin to run in the streams. The Arctic hare and red fox are not plentiful, but skins of the latter are offered for sale by the natives. Skins of muskrat and of a kind of ground squirrel are used by the native in making clothing; the flesh is also eaten. Geese, duclss, sandhill cranes, and swans were seen frequently, while the ever present ptarmigan many times furnished our party with fresh meat in place of the usual bacon. The "goose pasture" south of Pinnell River is well known to the prospectors of that region, and the numerous ponds are covered with thousands of young geese in August. Greyling and trout were caught in many of the streams; salmon were seen in the larger rivers and may be obtained from the natives, who spear them or catch them in nets. 


\section{TIMBER AND VEGETATION.}

Timbered land is confined entirely to the eastern part of Seward Peninstula. On the southern side of the IBendeleben Mountains scattered spruce trees were seen by Brooks in the valley of the Niukluk as far west as Libby River, which rises on the west side of Mount Bendeleben, while considerable timber was found lower down in the valley as far as Golofnin Bay. Eastward spruce grows along all the streams. On the northern side of the Bendeleben Mountains spruce is found in the valley of the Koyuk west to the vicinity of Timber Creek on the south and to the tributaries heading toward Kiwalik Mountain on the north. Scattered trees of small size were seen on Independence Creek, and good timber was found on Big Bar Creek, First Chance Creek, and Gold Run. The course of Kiwalik River and its larger tributaries, Hunter and Quartz creeks, may be readily traced at a distance by the narrow band of spruce timber lining the banks. This timber has been of great value to prospectors on Candle Creek, both as fuel and as material for building, so that many of the cabins at Candle are built of logs cut in the early spring and floated down the river. on the high water. From this brief description it will be seen that spruce extends considerably farther west on the south side of the Bendeleben Mountains than it does on the north, and that the timber limit is farther to the west in the central than in the coast regions. Large spruce logs are not infequently exposed in the muck and gravel of the valleys and suggest the possibility that the distribution of timber was once much greater than at present. It should be borne in mind, however, that the logs may have been derived from very distant sources and have been brought to their present resting place by water at a time when the land stood considerably lower with reference to the sea.

In point of size cottonwoods would be next in importance to spruce, but these are not widely distributed and are to be found only along a few of the streams. The greatest number were seen near the Cottonwood road house on the Kruzgamepa, or Pilgrim, River. A few were observed on Cottonwood Creek at the head of Goodhope River and in one or two other localities.

As a rule, the willows, which are found close to the streams in nearly all the valleys, do not have a height greater than 6 or 8 feet, although certain of them reach a size almost as great as the cottonwoods and are regarded by some of the prospectors as marking stream channels which have not varied much in position for a long time. While this is true to a certain extent, it is also probable that the character of the soil and the species of willows have much to do with the size of the tree. These willows, of which there is a great 
variety, from tiny shrubs of 2 or 3 inches to trees with a height of 20 feet, are the only fuel supply in the greater part of the peninsula and have made possible the exploration of the gold-bearing gravels. Winter snows have weighted them with a load greater than they could bear, and it is the usual experience to find the trunks so gnarled and twisted as to cause some trouble in taking a pack train through them.

Alders are much less abundant than willows, but often form considerable thickets.

No attempt was made to study the flora of the country traversed. The lowlands and hill slopes, at times the hill tops also, are covered with the moss and grass which characterize the tundras of the Arctic regions. During the warmer months no difficulty was experienced in finding good feed for the horses, for grass was plentiful in the valleys. The writer was told that some attempts had been made to cut and cure hay for feed and thus avoid the enormous expense of keeping horses through the winter, but that the attempts were not very successful, since the grasses have no chance to mature in the short season and do not afford much nourishment after curing. Several varieties of berries, especially the marsh blueberry and the salmon berry, are very abundant and furnish a most agreeable addition to the somewhat monotonous fare with which one is obliged to content himself in this region. The variety and abundance of flowers in the early part of the season is very surprising to one accustomed to think of Alaska only as a cold, barren waste covered with snow and swept by Arctic winds. 



\section{IN D EX.}

A.

Age of rocks

Alaska, mat of

topographic divisions of

Alder Beach diggtngs, location and character of, and de-

yield of velopment on

Alders, existence of Aldridge, John, mention of American Creek, location of and prospects on _.....

production on

tin on

Andesite, occurrence and character

Applegate, of - locations by

Asses Ears, altitude of

granite near, view of

rocks neal _.

vlews of

Automoblle boller, use of _....... 56

\section{B.}

Baldy Mountain, fossils found on Barnard, E. C., work of

Barr, Andrew, locations by -...

Basalt, occurrence and character of -

See also Lava.

Rear Creek, discovery of gold on -location and character of, and developments on

production on _............ 51,66

Benches, occurtence and character of -

Bendeleben Mountalns, history of $\rightarrow 35-36$ location and altitude of _-_-_-_ 16

IBelliles, existence of

Iblankenship, ——, locations by --

Bogoslof Island, formation of -.---

Brooks, Alfred H., letter of transmittal by

on coal

on geologic history -...-_-_-

on gold

on high bench deposits

on metamorphic rocks........-

on surficlal deposits

work of
24

$9-10$

50

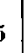

Luckland-Kiwalik divide. location and altitude of 16 rocks of _...

Buckland River, basin of, gold in course and character of flats on gold on length and location of

$$
\text { c. }
$$

Cabins, winter, view of

Candle, natives at_._. 76

recording office at

rendezvous at

timber near

view of _..... 60

Candle Creek, bench clatm on, view of 62

course and chatacter of, and development on $\ldots \ldots-48,60-63$

gold on

discovely of ........ $49-5$ in

groubil ice on

location of -

production of

reason for name of ._._. 50

rocks near

Cantwell, J. C., coal discovered by _.. 20 on natives. $\quad 76$

Cape Mountain, rocks at _._._._. 35

Cassiterite, discovery of

hicago Creek, coill from, cost of - _ coal on _...

investigations on 12

location of and developments on

rocks at.

Climate, character of _...

Coal, age of

cost of

development of

occurrence of $\ldots \ldots \ldots$. $18,25-0.0$, (67 use of _- 63

value of . 67

Coastal plain, character of

Collier, A. J., correlations by

fossils gathered by

on hasalt.... 31

on climate.... 71-79

on erosion epochs ..... 43 
Collier-Continued.

on folding

on lava

on lowlands _...

on metamorphic rocks_._._. 30

on Serpentine River deposits__- $\quad 39$

on Sewurd Peninsular rocks_..- 24

work of

Collins Creek, location of and prospects on

Correlation, difficulties of _____ 17,22

Cottonwood Creek, faulting on

lava at _.........................

view of

Cottonwoods, existence of

Creeks, description of

Cub Creek, gold on

Cunningham Creek, location and character of, and developments on _._._- $53-54$

production of

D.

Dall, W. II., on coal

on ground ice

on mammalian remains ....

on Nulato sandstone.....-..-

Darby Mountains, history of

Davis, W. H., locations by

Deering, communication with $\ldots \ldots \ldots$ location of _._._._._. 15,47 natives at $\ldots$ supplies shipped to

Deformation, periods of

Deposits, surficial, groups of _-_-__- $37-38$

Devil Mountain, charactel of lowlands near _..._._._._. 45

Diabase. occurrence and character of

Iblorlte, occurrence and character of

Dixie (reek, developments on_-_-_-_ 64-65 gold on

logs, use of

Jomes, occurrence of

I.orothy Creek, cache on

Mrainage of Seward Peninsula____ 15-16

E.

Eldorado Creek, rendezvous at rocks on and neal

Flephant Foint, ground ice at $\ldots . . .41$ shore line between Cape Espenberg and

Espenberg, Cape, shore line between Elephant Point and --

$$
\text { F. }
$$

Fairhaven precinct, mapping of Faults, occurrence of ............ Fee, W. 'T., discoveries by _.......

Finds, large, locations of $\ldots \ldots+59-60,62$

Fires, punișhment for stalting of ---

(a)

6

P'age.

Fish, existence of

Flowers, nbundance of _._.

Folds, occurrence of origin of _...

Fossils, destiuction of failure to obtaln _._._._. 19,25

lioster, Z. Is., locations by

Freighting, cost of _._. difficulties of _._._._._._. 58, (: $:-70$ methods of

French Creek, coal on_._._._. 25, 26, 67 Fuel, scarcity of

G.

Galena, occurrence of

Game, extermination of _....... 77

('ieography of gold field, account of -- 47-49)

Geologic sections. See Sections, geologic.

Geological Sulvey, U. S., investigations by _-_- $9-10$

Geology of Seward I'eninsula ____-_ 17-47 Geology, economic, of Seward I'enInsula -

(ierdine, 'T. G., wolk of

Glaciation, absence of $\ldots$

Gnelss, occurrence of

Gold deposits, location of production of source of

Gold field. divisions of geography of _-_._-_-_ 47-49 history of location, area, and character of $\quad 47$ Goodhope Bay, plain of, character of ............. 39

Shore of Goodhope River, length of Granite, age of erosion of, vlew of _._._._. 20 occurrence and character of - 18, 26-30 terrace of, view of Granite Creek. See Chicago Creek.

Grass, existence of _..._... 70,79

Gravels, deposition and charactel of - 37-40 occurrence of relation of lava and yield of -_._. 66

Gravels, wash, character of Grewingk Island, formation of _... 35

H.

Hannum Creek, discovery of gold on $\quad 49$ faulting on location and character of, and developments on production on l'ocks near _._._._._._._. 21 slulcing on, view of 48

II arris Creek, fossils found on _._._ 24

IIarris Iome, location of _..._... 20 rocks of 
l'igt:

Harry Creek, location of, and prospects on -

IIess, F. I., work of

Ilill, A. G., mention of

Hill, C. E., acknowledgments to

temperature records by

work of
History, dynamic, of Seward Peninsula_-_--_--------- $35-37$

IIistory, geologic, of Seward Peninsula_-_-_-

Horses, use of

Hot Springs, gold at view of .--

Howie, R. L., locations by

Hydraulic mining, preparations for 56,58

$$
\text { I. }
$$

Ice, ground, depth of 41 occurrence and character of $40-41,61$ Igneous rocks. See Rocks, Igneous.

Imuruk, Lake, lava at_-_-_-_-_-- 31-32 location and character of

Inmachuk River, basin of, gold in-- 51-60 cabins on, view of course and character of

dam on, view of

finds on

gold on _._- 11,12

discovery of ....- 49

ground ice on

investigation on 12

length of

location and character of, and developments on $---\ldots 58-60$

production on

pump on, view of

sluicing on, view of _._._. 60

Intrusive rocks, occurrence of _-_-- 18

Investigations on Seward Peninsula _ 9-14

Iron oxlde, occurrence of

Itinerary of surveys of 1903_--_-_- 11-14

$$
\text { J. }
$$

Jolınson, S. W., mention of

Jump Creek, discovery of gold on

K.

Kaltag series, correlation of

Kenat group, reference of coal to

Kigluaik Mountalns, history of

Kigluaik series, occurrence of

Kiwalik, communication with

location of

natives at

supplies shipped to

Kiwallk-Buckland divide, location and altitude of -

Kiwalik Mountain, altitude of

benches at

rocks of and negr__-_.-- 21, 22, 28

schist monuments near, view of
Kiwalik Iiver, basin of, gold in- $51,61-63$ course and churacter of flats on granite terrace near, view of --, 34 ground lce on lava near _...-...- 34

Knowlton, F. 1I., fossll determinations by

Kotzebue gold field, production of $--\quad 51$

Kotzebue Sound, communication with $1 \overline{5}$ history of ... 15 investigation at lava flows south of, diagram showing _--

rocks near.

Kowak River, coal on

Koyuk precinct, mapping of _...- 10

Koyuk River, course, length, and character of _------- 15-16

flats on

lava on rocks on _._.

Koyukuk River, lava on rocks on

Kugruk group, character and age of - 24 Kugruk Plateau, location and character of

Kugruk precinct, mapping of ---

Kugruk River, basin of, gold in_ 51,64-65 course and character of region of, rocks of rocks on

Kuzitrin River, basin of, formation $\begin{array}{ll}\text { of } & 37 \\ \text { character of } & 16 \\ \text { conditions on } & 12 \\ \text { course of } & 15 \\ \text { flats on } & 45 \\ \text { valley of, lava in } & 31 \\ \text { lava In, vlews of }\end{array}$

Kuzitrin serles, occurrence of

\section{L.}

Lanes Ianding, trip to-_--_--_- 12

Lava, age of flow of, drainage altered by $\ldots$ 32, 33 occurrence of diagram showing relation of gravel and _._. $\quad 33$ sources of views of $\ldots$

Lawson, A. C., on Maligne River rocks -

Limestone, occurrence and character of ---------- 17-18, 21-22

M.

Malls, provision for 70

Mammals, remains of

Mammoths, remalns of

Map of Alaska

of Seward Peninsula, showing mining precincts _-_-- 11 
Map, geologic, of part of Seward l'eninsula

areal covered by

distribution of gold shown on -making of

Milp, topographic, of part of Seward I'eninsula - -

of part of Seward l'eninsula. making of _._._. $12-14$

Marys Igloo, rendezvous at

Mathews, S. I., mention of _....

Mendenhall, IV. C., on Alder Beacl diggings -........

on basalt on coal _...

on granite

on lava

on metamorphic rocks _.......

on sediments _................

work of

Metamorphic rocks. See Rocks, metainorphic.

Midnight Mountain, location and altitude of

Mining precincts, map of

Moffit, F. H., assignment of

work of

Monument Mountain, character of -

Musk ox, remains of

$\mathbf{N}$.

Natives, condition of

Navigation, opening and close of -

Nelson, _., coal found by

Nelson Gulch, location and character of, and developments on

production on -

view in

Niagaran rocks, occurrence of

Nome, discovery of gold at

Nome series, divisions of

Noxapacra River, rocks on

Nugnugaluktuk River, course of

Nulato sandstone, age of

Nuluk Platean, remains of

0 .

Old (ilory creek, discovery of gold on -

gravel on

hydraulic mining on

investigation on

location and character of, and developments on $54-57$

production of

rendezvous on

tin from -

Ordovician rocks, oceurrence of _.. 24

$$
\text { I'. }
$$

Patterson, Alexander, locations by P'atter'son Creek, gravel at l'age. l'erry, M. V., locations by Perry Creek, discovery of gold on -location and chalacter of, and prospects on

l'eter's, W. J., work of l'eter'son, _-__-, coal found by .... l'innell, Jessie, locations by ........ l'innell River, course and character of _..._. 48,57 gold on hydraulic mining on _._._._. 58 investigation on location of, and prospects on production on rocks near._._.

I'oint Blossom, communication with $\quad 15$ investigation at loration of _._._._._. 15

l'ort Clarence limestone, character and age of

l'otato Creek, rocks on I'ot holes, character of l'recincts, mining, map of 11 I'ump, China, view o*-_._- 62 I'umps, use of

IR.

Ruins, prevalence of _.

Record, lava year -....... 58 location of

Richardson, G. B., work of _._._ 10

Ilockers, use of _._._._._. 63

Rocks, age of _. strike of _._._._._._._._. 22 structure of $\ldots \ldots$

Rocks, Igneous, character, occurrence, and age of $\ldots \ldots \ldots 18,26-35$

IRocks, metamorphic, character and occurrence of $\ldots \ldots-17-24$

Rocks, schistose, character and occurrence of .

liocks, sedimentary, character and occurrence of _-_._- $17-26$

loust, --_, coal found by

$$
\text { s. }
$$

St. Michael Island, lava of _._._. $\quad 34$

Sandstrum, Fred, locations by

Schists, occurlence of

weathering of, view of

Schnelder, Robert, locations by

Schrader, F. C., work of ........ 9

Scraper's, hor'se, use of .

Seasons, length and character of $68-69,71$

Section, geologic, on Candle Creek on Inmachuk River.______. 59

on Nelson Gulch

Sedimentary rocks. See Rocks, sedimentary.

Serpentine River, deposits of _....-

Seward Peninsula, discovery of gold

$\begin{array}{lr}\text { geography of } & 9 \\ \text { geologic map of part of } & 18 \\ \text { geology of } & \end{array}$

yeology of 
Seward Peninsula-Continued.

gold on

investigations on

map of

precinct map of

rocks of

topographic map of part of

Sherdon Creek, gold on

Shishmaref Inlet, location of ..---

Silt. deposition of

Siluilan rocks, occurrence of

Sluicing, view of

Soil, residual, character of -

Spruce, existence of

Spurr, J. E., on lava

Strike of rocks

Structure of rocks

Stuver, I. D., mention of

$\mathrm{T}$.

Teller, conditions at supplies shipped to

Temperatures, records of

Tendness, Louis, locations by

Terraces, gravel, occurrence of

Thawer, view of
Page.

'Thawer, improvised, view of

Page

9-14

11

11

17-35

16

64

39

37

24,35

48 ; 60

40

39

10

78

34-35

22

22-23

10

12

11

73-75

50

$39-40$

64

Thawers, use of ........ 60, 63

'Whomas, Enos, locations by

'Timber; charncter of _._._._. $78-79$

scareity of .......... $70-71$

'Tin, occurrence of -

Topography, character of

Trail Creek, faulting on

'Trails, location and character of--- 63-64,

68-69

Tubutulik River, rocks on _-_-_-_-_ 25, 26

W.

Weather, condition of

Whitehead, Cabell, information from

Willow Creek, gravel at_______- 61

Willows, existence of _._._._. $78-79$

Witherspoon, B. W., mention of ..- 10

Witherspoon, D. C., acknowledg-

$\begin{array}{lr}\text { ments to } & 19 \\ \text { on benches } & \\ \text { work of } & \end{array}$

Y.

York Plateau, location and character of

York reglon, tin deposits of

Yukon River, locks on _._. 25 



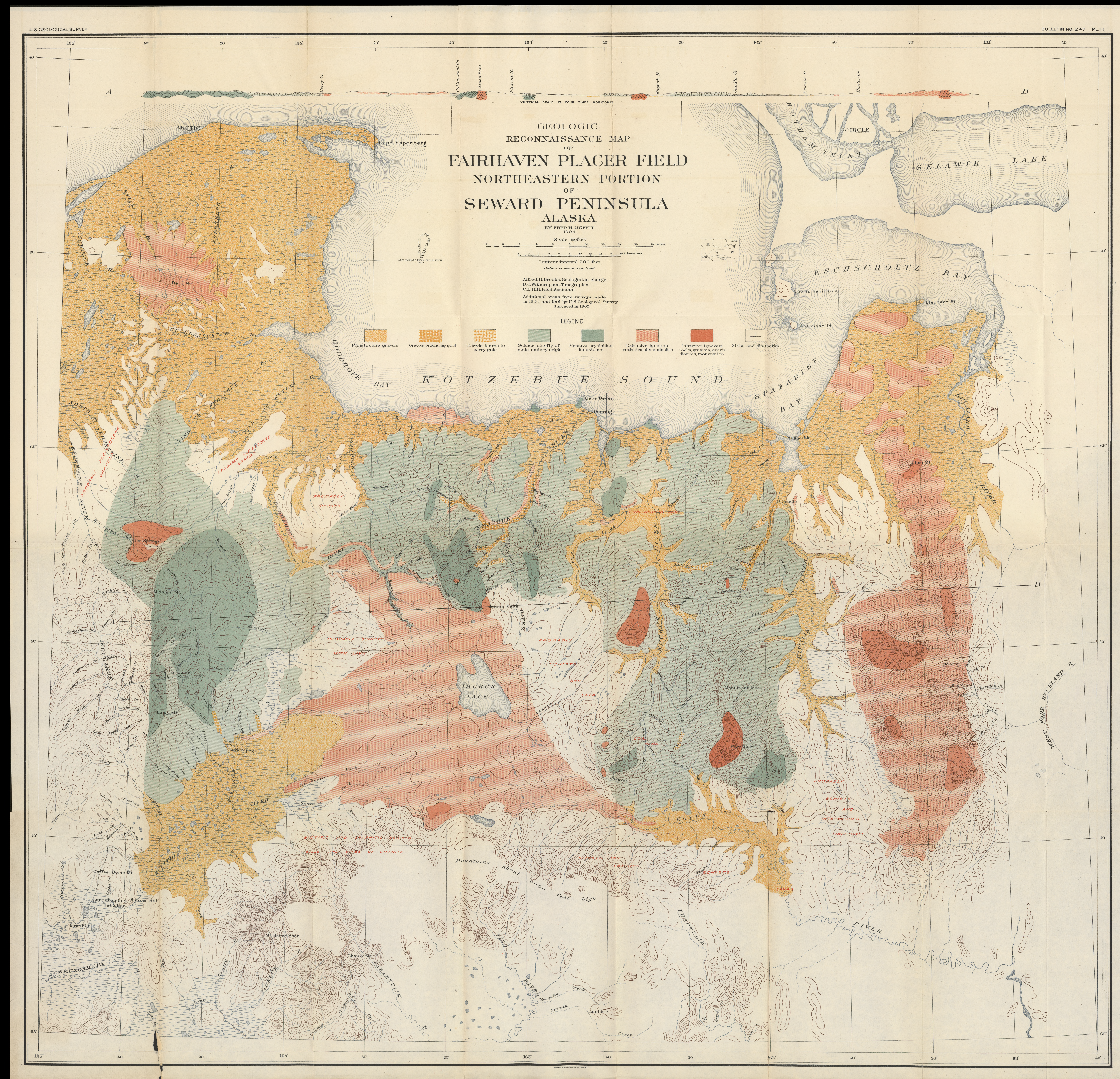




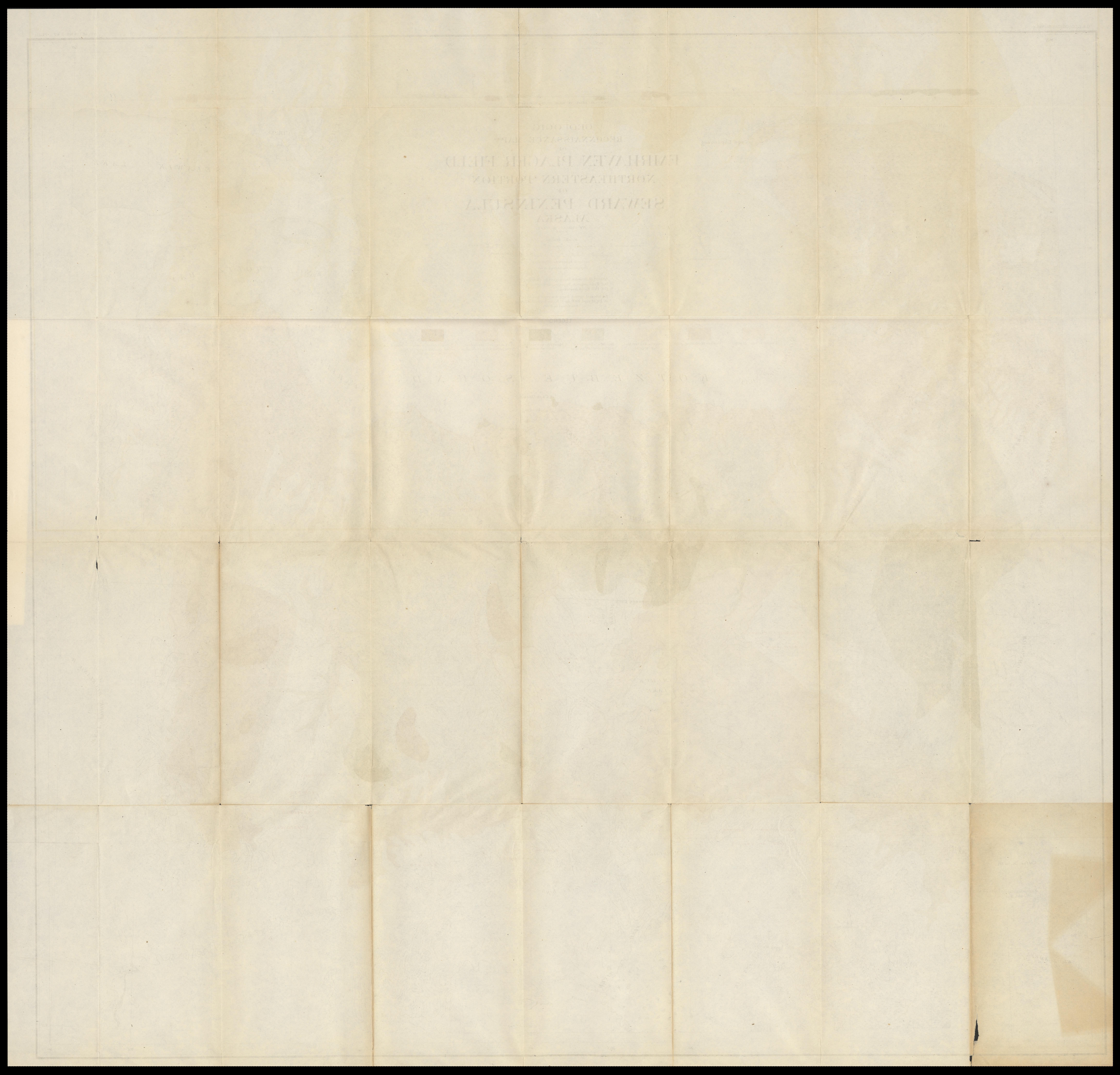




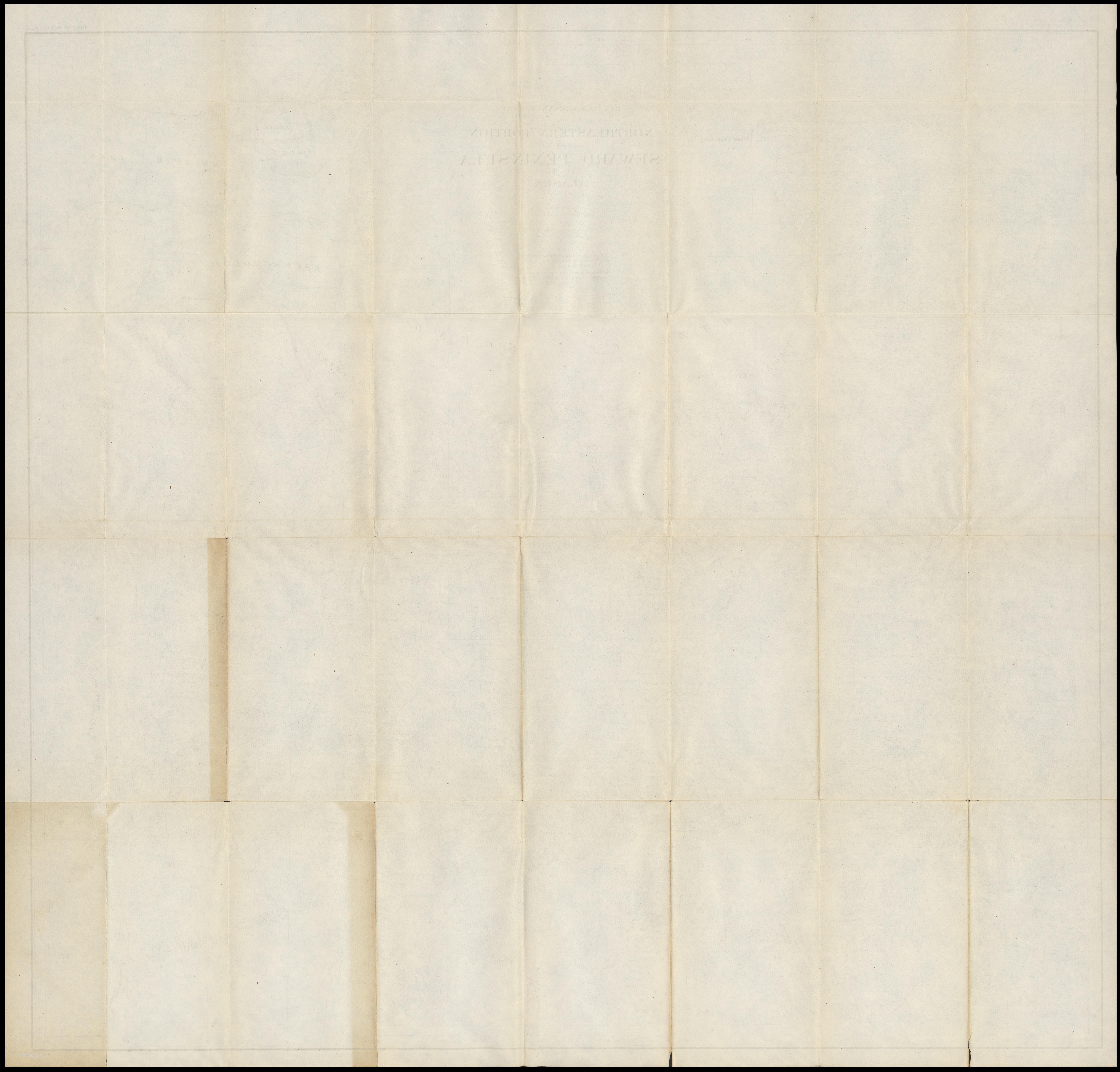

